\title{
Simulation of Ground-Water Flow and Potential Land Subsidence, Upper Santa Cruz Basin, Arizona By R.T. HANSON and J.F. BENEDICT
}

U.S. GEOLOGICAL SURVEY

Water-Resources Investigations Report 93-4196

Prepared in cooperation with the CITY OF TUCSON

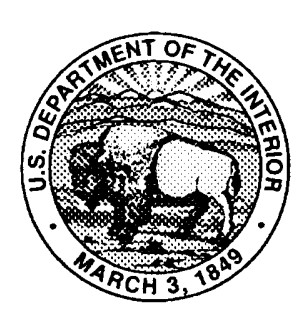




\title{
U.S. DEPARTMENT OF THE INTERIOR BRUCE BABBITT, Secretary
}

\author{
U.S. GEOLOGICAL SURVEY
}

Gordon P. Eaton, Director

For additional information write to:

District Chief

U.S. Geological Survey Water Resources Division

375 South Euclid Avenue Tucson, AZ 85719-6644
Copies of this report can be purchased from:

U.S. Geological Survey Earth Science Information Center Open-File Reports Section Box 25286, MS 517 Denver Federal Center Denver, CO 80225 


\section{CONTENTS}

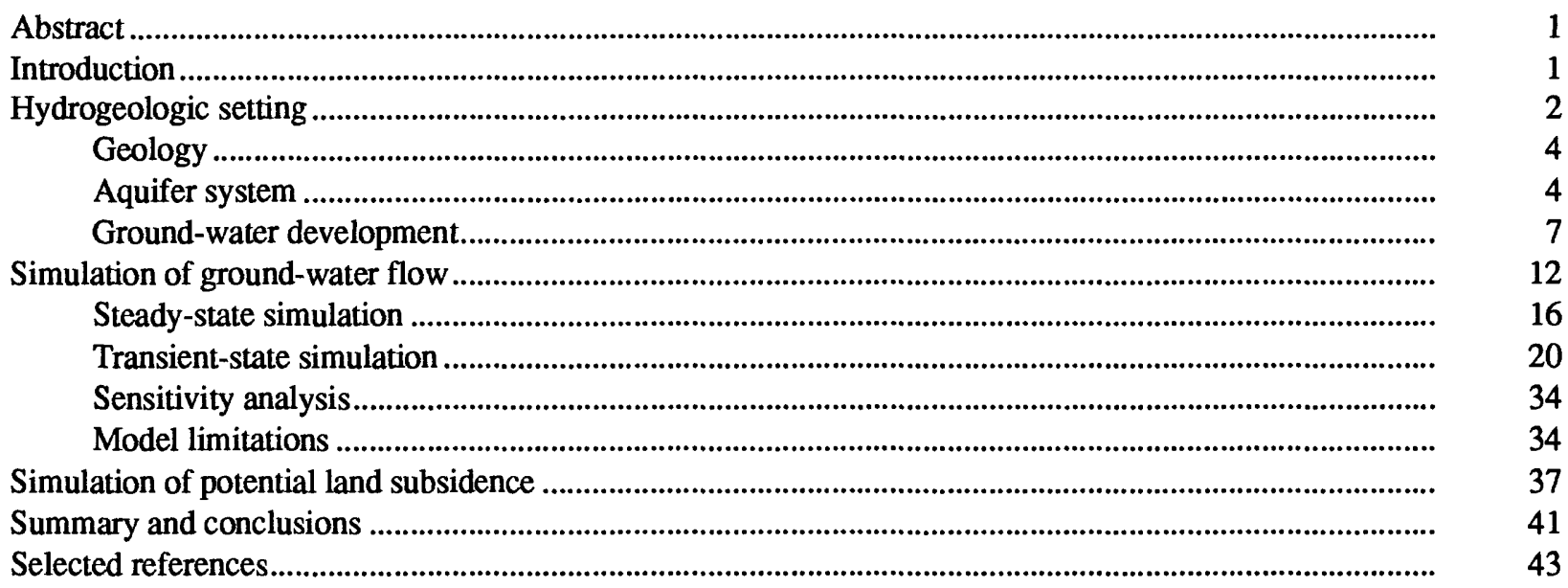

\section{FIGURES}

1.-2. Maps showing:

1. Location of study area

2. Extent of alluvium and depth to bedrock in the upper Santa Cruz basin

3. Diagram showing generalized hydrogeologic section of the upper

Santa Cruz basin

4.-5. Graphs showing:

4. Annual streamflow in the Santa Cruz River at

Continental, upper Santa Cruz basin, 1940-86

5. Annual reported ground-water pumpage in the part

of the upper Santa Cruz basin in Pima County, 1940-86

6-12. Maps showing:

6. Finite-difference grid with boundary conditions

for layers 1 and 2 of the upper

Santa Cruz basin ground-water model

7. Finite-difference grid with mountain-front recharge

for layers 1 and 2 of the upper Santa Cruz basin

ground-water model

8. Finite-difference grid with average silt and clay contents

for layers 1 and 2 of the upper Santa Cruz basin

ground-water model

9. Simulated evapotranspiration (1940) and average streamflow recharge (1941-57) for layers 1 and 2 of the upper

Santa Cruz basin ground-water model

10. Hydraulic conductivity and simulated steady-state saturated thickness

of model layer 1 of the upper Santa Cruz basin ground-water model .......................................... 21

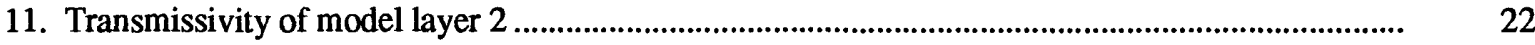

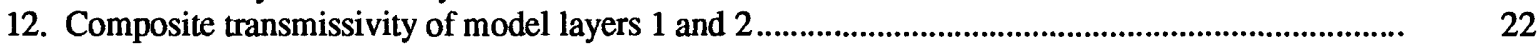

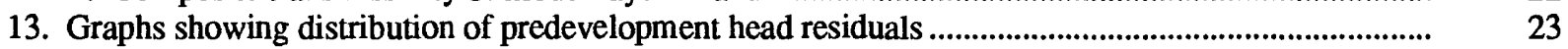




\section{FIGURES-Continued}

14-16. Maps showing:

14. Measured and simulated ground-water levels for model layer 2

of the upper Santa Cruz basin, 1940

15. Specific yield of model layers 1 and 2

16. Simulated evapotranspiration (1986) and average streamflow recharge (1958-86) for layers 1 and 2 of the upper

Santa Cruz basin ground-water model

17. Graph showing estimated and simulated average annual pumpage, by simulation interval, in the upper Santa Cruz basin, 1940-86

18. Map showing measured and simulated ground-water levels for layer 2 in the upper Santa Cruz basin, 1986

19. Hydrographs showing measured and simulated depth to water in selected wells in the upper Santa Cruz basin, 1940-86.

20-21. Maps showing:

20. Potential water-level decline, 1940-2025, and minimum land subsidence, 1987-2025, in the upper Santa Cruz basin

21. Potential water-level decline, 1940-2025, and maximum land subsidence, 1987-2025, in the upper Santa Cruz basin

22. Graphs showing subsidence projection budget components for the upper Santa Cruz basin, 1987-2025

\section{TABLES}

1. Summary of estimated ground-water flow components for the upper Santa Cruz basin

2. Summary of estimated mountain-front recharge for mountains surrounding the upper Santa Cruz basin

3. Summary of estimated and simulated average streamflow-infiltration recharge for the upper Santa Cruz basin

4. Summary of transient simulated ground-water flow components for the upper Santa Cruz basin model

5. Summary of sensitivity analysis 


\begin{tabular}{lll}
\hline Multiply & By & To obtain \\
\hline inch (in) & 25.4 & millimeter \\
foot (ft) & 0.3048 & meter \\
mile (mi) & 1.609 & kilometer \\
square mile $\left(\mathrm{mi}^{2}\right)$ & 2.590 & square kilometer \\
acre-foot $($ acre-ft) & 0.001233 & cubic hectometer \\
cubic foot per second $\left(\mathrm{ft}^{3} / \mathrm{s}\right)$ & 0.02832 & cubic meter per second \\
foot per day per foot $(\mathrm{ft} / \mathrm{d}) / \mathrm{ft}$ & 1 & meter per day per meter \\
foot squared per day $\left(\mathrm{ft}^{2} / \mathrm{d}\right)$ & 0.0929 & meter squared per day \\
\hline
\end{tabular}

\section{WELL-NUMBERING AND NAMING SYSTEM}

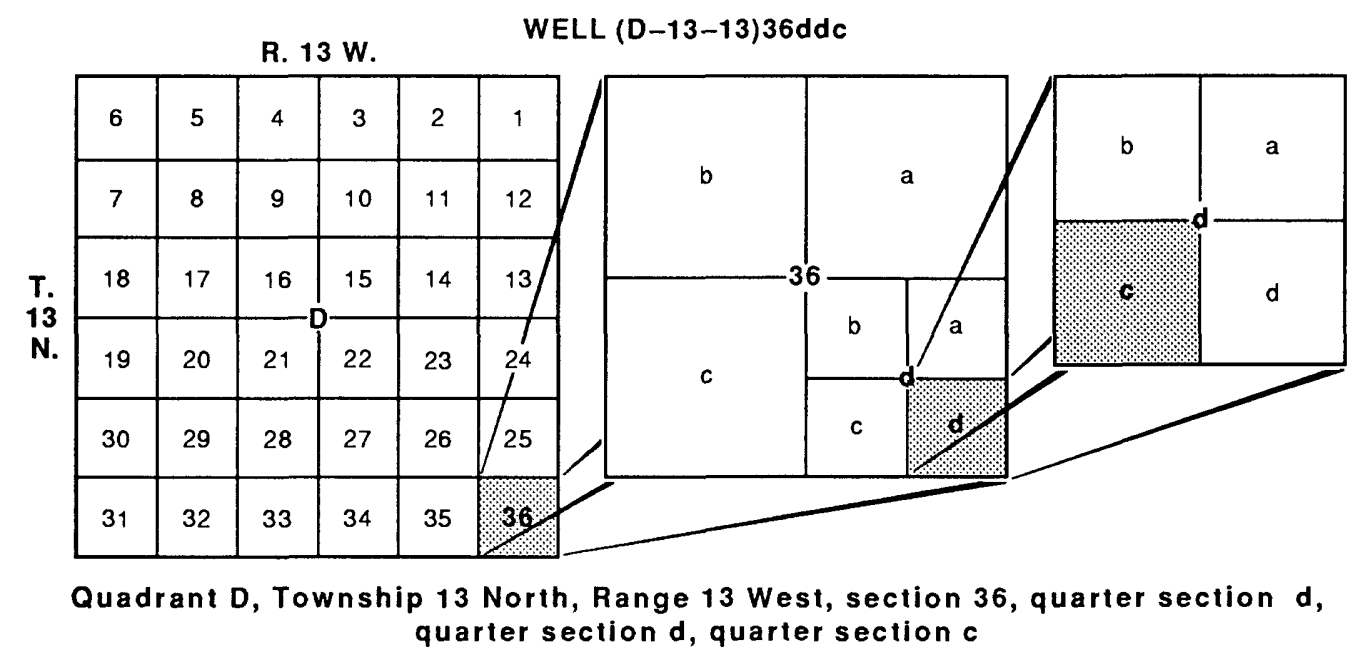

The well numbers used by the U.S. Geological Survey in Arizona are in accordance with the Bureau of Land Management's system of land subdivision. The land survey in Arizona is based on the Gila and Salt River meridian and base line, which divide the state into four quadrants and are designated by capital letters A, B, C, and D in a counterclockwise direction, beginning in the northeast quarter. The first digit of a well number indicates the township, the second the range, and the third the section in which the well is situated. The lowercase letters a, b, c, and d after the section number indicate the well location within the section. The first letter denotes a particular 160-acre tract, the second the 40-acre tract and the third the 10-acre tract. These letters also are assigned in a counterclockwise direction, beginning in the northeast quarter. If the location is known within the 10 -acre tract, three lowercase letters are shown in the well number. In the example shown, well number (D-13-13)36ddc designates the well as being in the SE1/4, SE1/4, SW1/4, section 36, Township 13 North, and Range 13 West. Where more than one well is within a 10-acre tract, consecutive numbers beginning with 1 are added as suffixes.

\section{VERTICAL DATUM}

Sea level: In this report "sea level" refers to the National Geodetic Vertical Datum of 1929_A geodetic datum derived from a general adjustment of the first-order level nets of the United States and Canada, formerly called "Sea Level Datum of 1929." 


\title{
Simulation of Ground-Water Flow and Potential Land Subsidence, Upper Santa Cruz Basin, Arizona
}

\author{
By R.T. Hanson and J.F. Benedict
}

\section{Abstract}

A numerical ground-water flow model of the upper Santa Cruz basin in Pinal, Pima, and Santa Cruz Counties, Arizona, was developed to evaluate predevelopment conditions in 1940, groundwater withdrawals for 1940-86, and potential water-level declines and land subsidence for 1987-2024. In the upper Santa Cruz basin, the alluvium is made up of upper and lower regional units that are saturated at depth and form a complex regional-aquifer system. Analyses of steady-state ground-water conditions indicate about 12,900 acre-feet of ground-water inflow, 15,260 acre-feet of outflow, 53,000 acre-feet of predevelopment pumpage, 7,890 acre-feet of evapotranspiration, 29,840 acre-feet of mountain-front recharge, and 34,020 acre-feet of streamflow infiltration in 1940. Analyses of transient ground-water conditions indicate a total of 6.6 million acre-feet of net pumpage and 3.4 million acre-feet of water removed from aquifer storage for 1941-86. A difference of 1.2 million acre-feet between estimated and net pumpage is attributed to increased recharge from irrigation return flow, mine return flow, and infiltration of sewage effluent.

Natural recharge was estimated to be 40 percent of the pumpage for 1966-86 and averaged 63,860 acre-feet per year for 1940-57 and 76,250 acre-feet per year for 1958-86. The increase in recharge after 1958 was coincident with above-average winter streamflow in the Santa Cruz River for 1959-86. Return flow from ground-water pumpage was estimated to be 21 percent of the pumpage for 1966-86 and averaged 14,590 acre-feet per year for 1941-65 and 39,650 acre-feet per year for 1966-86. Increased recharge after 1958 and decreased pumpage after 1975 contributed to decreased water-level declines or to recoveries after 1977 in wells near the Santa Cruz River and its tributaries.

The results of projection simulations indicate that a maximum potential subsidence for 1987-2024 ranges from 1.2 feet for an inelastic specific storage of $1.0 \times 10^{-5}$ per foot to 12 feet for an inelastic specific storage of $1.5 \times 10^{-4}$ per foot. The simulations were made on the basis of pumpage and recharge rates from 1986 and by using a preconsolidation-stress threshold of 100 feet. A permanent reduction in aquitard storage can range from 1 to 12 percent of the potential loss of 3.9 million acre-feet in aquifer-system storage for 1987-2024. Potential water-level declines were largest using the smallest assumed compressibilities. Potential declines for 1940-2024 ranged from 411 to 438 feet for the maximum and minimum subsidence projections, respectively.

\section{INTRODUCTION}

The upper Santa Cruz basin is a 2,870square-mile alluvial basin in northern Sonora, Mexico, and in Pima, Pinal, and Santa Cruz
Counties, Arizona (fig. 1). The basin, which is bounded on the east by high mountains and on the west by low-lying mountains, consists of a northtrending gently sloping alluvial plain that is 5 to $20 \mathrm{mi}$ wide (fig. 2). The basin is underlain by an 


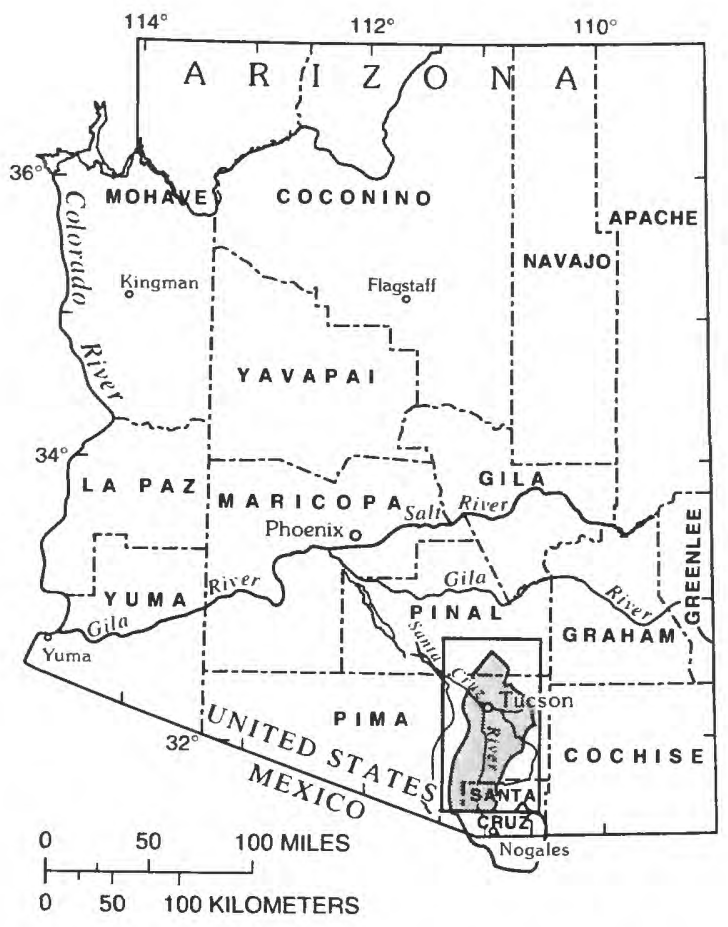

Figure 1. Location of study area (shaded).

extensive alluvial-aquifer system. The aquifer system consists of a wide variety of sedimentary deposits that range from gravel and conglomerate to anhydritic and gypsiferous clayey silt and mudstone.

Pumping of ground water for agriculture, public supply, and industry resulted in widespread water-level declines that ranged from 50 to $150 \mathrm{ft}$ for 1940-81 (Babcock and Hix, 1982). Declines were accompanied by localized compaction of the aquifer and subsidence of the land surface (Anderson, 1988, fig. 7). Continued withdrawals from the aquifer could result in additional waterlevel declines and potential subsidence. Anderson (1988) concluded that subsidence, which ranged from 0 to $0.5 \mathrm{ft}$ between 1951 and 1980 , could ultimately exceed $10 \mathrm{ft}$ in parts of the basin. Fissuring, which is an extreme consequence of subsidence, has not yet occurred in the study area; however, fissuring potentially could occur with this amount of projected subsidence. Consequences from subsidence could include permanent reduction of aquifer storage as well as damage to highways, railroads, buildings, aqueducts, irrigation systems, wells, and sewage systems. Subsidence of as much as $12.5 \mathrm{ft}$, water-level declines of $300 \mathrm{ft}$ (Laney and others, 1978), and related earth fissures (Carpenter, 1991) have already occurred in the adjacent Picacho basin just north of Tucson. The aquifer system received sole-source designation by the U.S. Environmental Protection Agency in 1984 (U.S. Environmental Protection Agency, 1984). Management of this natural resource could require periodic reevaluation of the effects of compaction and subsidence in order to minimize potential environmental damage related to ground-water development.

In 1979, the U.S. Geological Survey, in cooperation with the City of Tucson, began an investigation to evaluate the potential for aquifer compaction, land subsidence, and earth fissures in the central part of the upper Santa Cruz drainage basin known as the Tucson basin (Anderson, 1988). The study was divided into three phases: a detailed hydrogeologic investigation (Anderson, 1988), a stress-strain analysis of extensometer data (Hanson, 1987, 1989), and the development of a regionalsubsidence model. This report documents the results and procedures used to develop a numerical simulation of ground-water flow and subsidence of the upper Santa Cruz basin. The simulation was calibrated through 1986 and was used to evaluate the potential for water-level decline and land subsidence from 1987 through 2024 . The year 2025 was designated by the Arizona Ground-Water Management Act of 1980 (State of Arizona, 1980) as the time by which pumpage and recharge must be brought into balance. Because any estimation of "safe yield conditions" could be affected by ground water derived from aquitard storage, these projections give some indication of the relative onetime contribution from this source of ground water.

\section{HYDROGEOLOGIC SETTING}

The upper Santa Cruz basin is in the Basin and Range Physiographic Province, which is characterized by block-faulted mountains separated by sediment-filled basins (Fenneman, 1931). The mountains are composed of granitic, metamorphic, volcanic, and indurated sedimentary rocks of Precambrian through Tertiary age. Sediments of the basin consist of unconsolidated to indurated gravel, sand, silt, and clay of Tertiary and 

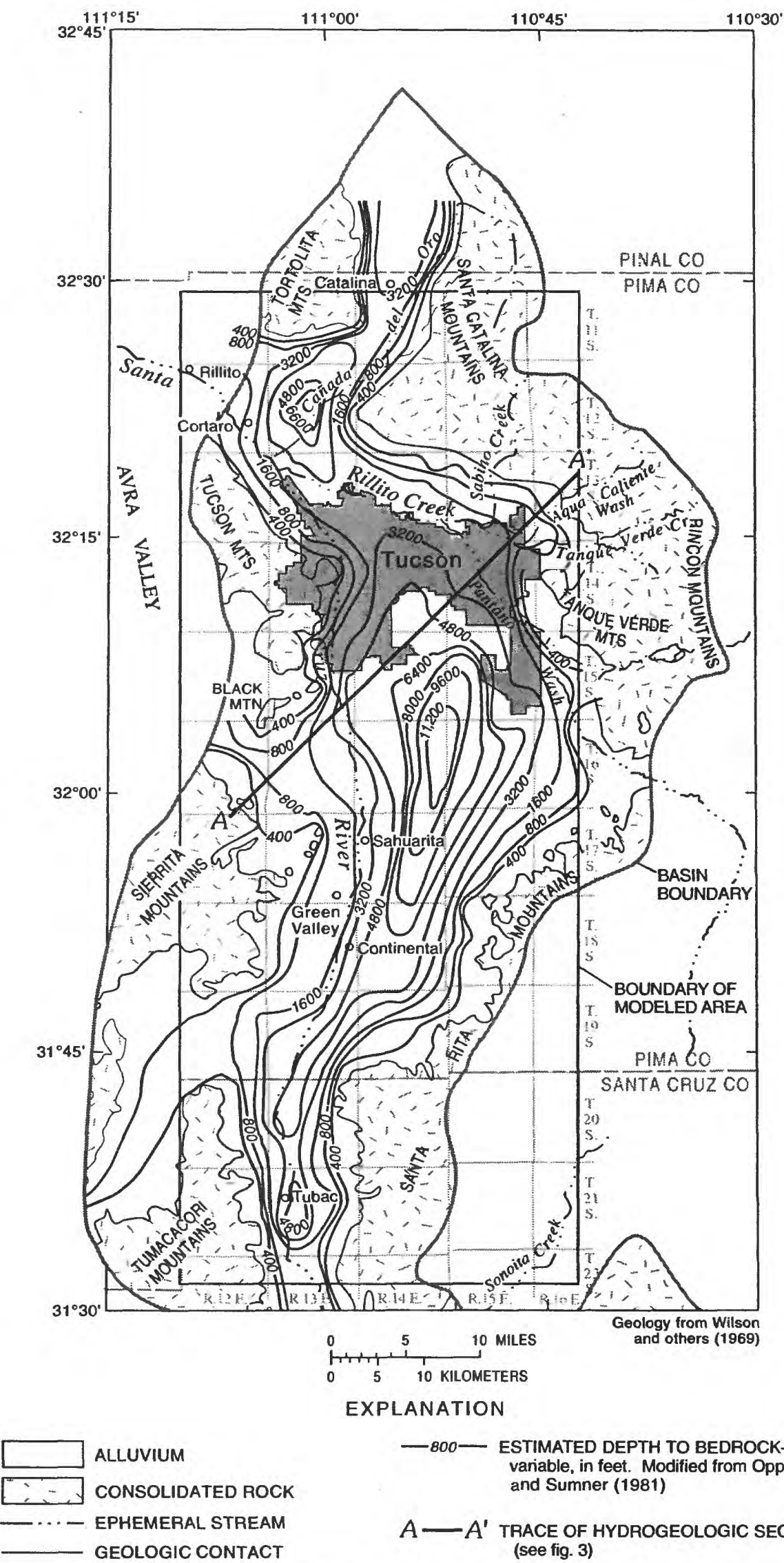
- $800-$ ESTIMATED DEPTH TO BEDROCK-Interva variable, in feet. Modified from Oppenheimer and Sumner (1981)
$A-A^{\prime}$ TRACE OF HYDROGEOLOGIC SECTION (see fig. 3)

Figure 2. Extent of alluvium and depth to bedrock in the upper Santa Cruz basin. 
Quaternary age. Sediments generally are coarse grained along the margins of the basin and grade to fine-grained and evaporitic deposits in the central downfaulted parts, or grabens, of the basin (Anderson, 1989, figs. 2-5).

Sediments are saturated at depth and are part of a regional-aquifer system of south-central Arizona (Anderson and others, 1990). Water stored in the aquifer generally is unconfined to depths of $1,500 \mathrm{ft}$ and moves in a northerly direction. Sources of water to the aquifer include ground-water inflow, mountain-front recharge, infiltration of streamflow and sewage effluent, and irrigation and mine return flow. Discharge of water from the aquifer includes ground-water outflow, evapotranspiration, and pumpage. Ground-water pumping has greatly altered the natural flow system and has caused widespread water-level declines. These declines resulted in reductions in evapotranspiration, changes in horizontal flow paths, development of vertical-hydraulic gradients and perched zones, and compaction of the aquifer.

\section{Geology}

The upper Santa Cruz basin contains a variety of igneous, metamorphic, and sedimentary rocks of Precambrian through Quaternary age. Rocks of primary interest to this study are sedimentary deposits of Tertiary and Quaternary age, referred to as alluvium (fig. 2). The mountains are composed mainly of relatively impermeable crystalline rocks that impede the movement of ground water. Along the extreme edges of the basin, bedrock is overlain by a veneer of alluvium that generally is less than $100 \mathrm{ft}$ thick. In the center of the basin, bedrock is overlain by more than $11,200 \mathrm{ft}$ of alluvium (fig. 2).

The alluvium consists of several regionally extensive sedimentary units of diverse lithology (Anderson, 1988). The alluvium is subdivided into lower and upper units on the basis of regional hydrogeologic characteristics (fig. 3). The lower alluvium consists of gravel and conglomerate to gypsiferous and anhydritic clayey silt and mudstone and is thousands of feet thick. The upper alluvium consists mainly of gravel, sand, and clayey silt and ranges from less than 100 to about $1,000 \mathrm{ft}$ in thickness. Deposits generally are coarse grained north of T. $13 \mathrm{~S}$. and fine grained in the south half of the basin within the central grabens (Anderson, 1989, figs. 4 and 5). The lower alluvium is equivalent to the Pantano Formation, lower Tinaja beds, and middle Tinaja beds described by Anderson (1987, 1988, 1989) and the regional lower basin fill of Pool (1986). The upper alluvium is equivalent to the upper Tinaja beds and Fort Lowell Formation (Anderson, 1987, 1988, 1989) and the regional upper basin fill and stream alluvium of Pool (1986). Geologic and geophysical data indicate that the sediments of the upper alluvium generally are much more compressible compared with those of the lower alluvium and are more likely to compact from the withdrawal of ground water (Anderson, 1988; Tucci and Pool, 1986).

Compaction environments within the upper alluvium include those in playa and alluvial-fan subregions and a fluvial zone where fan and playa sediments interfinger, herein referred to as the interfingered subregion. These zones or subregions were delineated on the basis of frequency of layering and the thickness-weighted average clay and silt content of the upper Tinaja beds and the Fort Lowell Formation over the saturated thickness in 1979 (Anderson and Hanson, 1987). Fan and playa subregions generally are characterized by clay and silt contents of less than 20 percent and more than 60 percent, respectively. The interfingered subregion generally contains from 20 to 60 percent clay and silt. This subregion was subdivided into two adjacent subregions with 20 to 40 and 40 to 60 percent clay and silt for subsidence evaluation (Anderson, 1988). The physical properties and evolution of Cenozoic deposits in the upper Santa Cruz basin and adjacent alluvial basins are described in more detail by Davidson (1973), Eberly and Stanley (1978), Pool (1986), Tucci and Pool (1986), Anderson (1987, 1988, 1989), Hanson (1989), and Anderson and others (1990).

\section{Aquifer System}

The lower and upper alluvium are saturated at depth and form a complex regional-aquifer system (fig. 3) that is underlain and bounded on the east and west by impermeable bedrock. The aquifer system generally is unconfined or partly confined to depths 

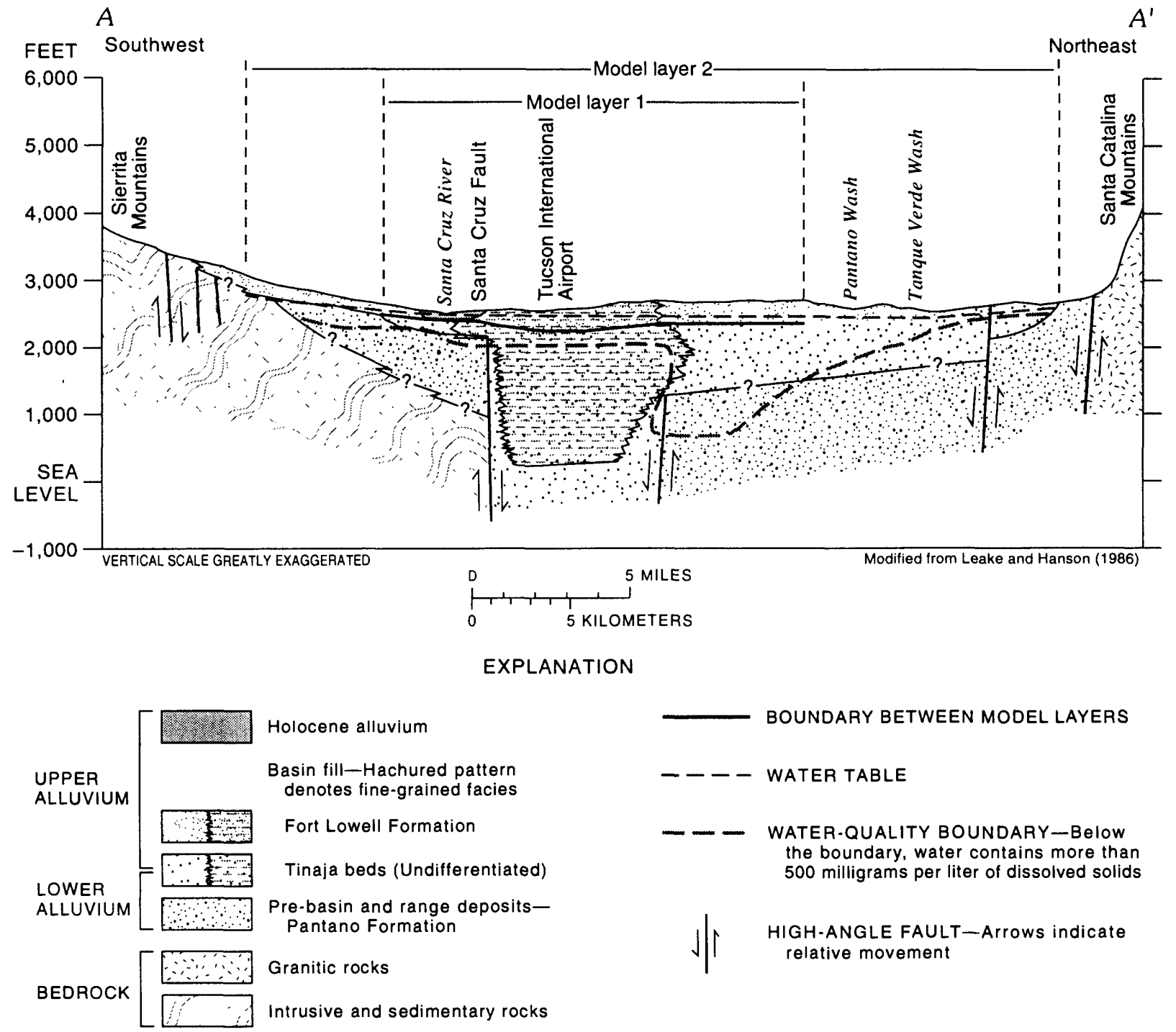

Figure 3. Generalized hydrogeologic section of the upper Santa Cruz basin. (Trace of section shown in fig. 2.)

of 1,500 $\mathrm{ft}$ (Davidson, 1973; Leake and Hanson, 1987; Hanson, 1989). Inflow to the aquifer system occurs as ground-water underflow and areal recharge. Outflow occurs as ground-water underflow, evapotranspiration, and pumpage.

Ground-water underflow to the aquifer in the study area occurs as inflow through alluvium-filled gaps in the bedrock in the upper Santa Cruz basin south of Tubac and north of Catalina along Cañada del Oro. Estimates of ground-water underflow range from $500 \mathrm{acre}-\mathrm{ft} / \mathrm{yr}$ at the international boundary to 10,575 acre-ft/yr near Tubac (table 1). Estimates of ground-water underflow from Canada del Oro range from 1,000 to 10,000 acre- $\mathrm{ft} / \mathrm{yr}$ (table 1). Ground-water underflow is locally significant relative to areal recharge in the north and south ends of the basin (Burkham, 1970; Anderson, 1972; Osterkamp, 1973).

Areal recharge to the aquifer includes streamflow infiltration, mountain-front recharge, irrigation return flow, and sewage-effluent and mine return flow. Streamflow infiltration and mountain-front recharge from precipitation are the primary natural sources of water to the aquifer in the upper Santa Cruz basin (table 1). Mean annual precipitation is about $15.5 \mathrm{in}$. for the entire drainage basin. Annually, the bottomland of the basin typically receives from 11 to $16 \mathrm{in}$. of precipitation, 
the western mountains from 16 to 20 in., and the eastern mountains from 16 to more than 30 in. Natural streamflow generally is of short duration and occurs in direct response to summer, fall, and winter rainfall. Streamflow can occur for longer periods, however, in response to some fall and winter rainfall and annual spring snowmelt from the northern and eastern mountains. The area is drained by the Santa Cruz River and its tributariesSonoita, Tanque Verde, Sabino, and Rillito Creeks; Cañada del Oro; and Agua Caliente and Pantano Washes (fig. 2). Estimates of streamflow infiltration in the basin range from 45,000 to $77,300 \mathrm{acre}-\mathrm{ft} / \mathrm{yr}$ for predevelopment and development conditions, respectively (table 1). Previous modeling studies, which did not include evapotranspiration in the simulations, used about 19,000 acre-ft/yr of streamflow infiltration (table 1). Recharge by streamflow infiltration was the largest during the record flow years of 1978, 1979, and 1984 (fig. 4) and could increase through time from increased discharge and infiltration of sewage effluent.

Before 1870 , streamflow was intermittent and about 80 percent of the Santa Cruz River was predominantly dry between the towns of Continental and Rillito (Betancourt and Turner, in press). From the 1870 's through the 1890 's, increased development of canal systems in the bottomlands of the Santa Cruz Valley combined with cycles of flood and drought promoted development of an entrenched main stem river channel through related headcut erosion at diversion points (Betancourt and Turner, in press). Before channelization of the Santa Cruz River in the 1890 's, short reaches of perennial streamflow between Continental and Rillito were largely the result of ground-water seepage. The Santa Cruz River and its tributaries are now in established channels and are restricted largely to these channels in urban areas.

The largest sources of mountain-front recharge are the Santa Catalina, Tanque Verde, Rincon, Santa Rita, and Sierrita Mountains (table 2). These mountains are the highest along the basin boundary and receive the largest amount of precipitation. Mountain-front recharge, which is thought to occur generally through minor tributary canyons along the ranges bounding the upper Santa Cruz River basin, is largest for the Santa Catalina, Rincon, and
Santa Rita Mountains and is least for the Tucson Mountains.

Recharge from return flow was estimated to be a larger source of water than mountain-front recharge after 1965, although estimates of mountain-front recharge by different investigators are variable (table 2), differing by more than a factor of two. Since 1965, areal recharge includes less return flow of water applied to fields adjacent to the Santa Cruz River and Rillito Creek and includes more infiltration of streamflow and sewage effluent along the channel and flood plain of the Santa Cruz River. Irrigation return flow probably will continue to decrease through time because of improved methods of irrigation and decreased irrigated acreage. Discharge of sewage effluent into the Santa Cruz River near Tucson began in 1950, averaged 5,600 acre-ft/yr in 1951, and increased to more than $49,000 \mathrm{acre}-\mathrm{ft} / \mathrm{yr}$ by 1985 (Davis and Stafford, 1966; Dave Esposito, Environmental Planning Management, Pima County Wastewater Management Department, oral commun., 1988). Seepage from tailings ponds was a significant source of return-flow recharge during the 1960's and 1970's but was substantially reduced in the early 1980 's as copper mining was largely curtailed.

Ground-water outflow from the aquifer occurs as underflow through an alluvium-filled gap in the bedrock near Rillito and as evapotranspiration along the flood plains of the Santa Cruz River, Rillito Creek, and major tributaries. Estimates of ground-water outflow near Rillito range from 3,000 to $20,100 \mathrm{acre}-\mathrm{ft} / \mathrm{yr}$ (table 1). Estimates of evapotranspiration were from 15,000 to 55,700 acre- $\mathrm{ft} / \mathrm{yr}$ for predevelopment conditions and about $6,000 \mathrm{acre}-\mathrm{ft} / \mathrm{yr}$ in the early 1960's (table 1; Davidson, 1973). Prior to complete entrenchment of the Santa Cruz River channel by 1914 and growing agricultural development along the flood plain in the early part of the 1900 's, infiltration along most of the Santa Cruz and parts of the Rillito probably was balanced by evapotranspiration from mesquite bosques. After 1940, significant waterlevel declines from agricultural pumping and related reduction of mesquite bosques resulted in less evapotranspiration in the form of additional streamflow infiltration to the aquifer system along the north-central part of the Santa Cruz and along the Rillito (table 1). 
Direction of ground-water movement generally is northward in the southern part of the basin and northwestward in the northern part. Movement and storage of ground water are controlled by the distribution of hydraulic head and by the transmissive and storage properties of the aquifer. Hydraulic properties of the lower and upper alluvium differ considerably from place to place, depending on lithologic factors such as sediment grain size, sorting, and cementation. In general, the lower alluvium is less transmissive than the upper alluvium but stores a much greater volume of water because of its greater thickness.

Transmissive properties of the aquifer are greatest in the upper alluvium along the channel of the Santa Cruz River and the major tributaries and are least in the mudstone facies of the lower alluvium. On the basis of overall aquifer-test data, hydraulic conductivity of the aquifer ranges from 1 to $1,100 \mathrm{ft} / \mathrm{d}$ with most values from 10 to $290 \mathrm{ft} / \mathrm{d}$ and transmissivity ranges from about 330 to $55,000 \mathrm{ft}^{2} / \mathrm{d}$ with most values from 1,000 to $28,000 \mathrm{ft}^{2} / \mathrm{d}$ (G.W. Freethey and W.R. Meyer, U.S. Geological Survey, written commun., 1982; unpublished data from the files of Tucson Water, City of Tucson; Anderson, 1972; Williams, 1987). Estimates of hydraulic conductivity ranged from 1 to $240 \mathrm{ft} / \mathrm{d}$ in the lower alluvium, 3 to $425 \mathrm{ft} / \mathrm{d}$ in most of the upper alluvium, and 300 to $1,100 \mathrm{ft} / \mathrm{d}$ in the river gravels of the upper alluvium that underlie the channel of the Santa Cruz River (G.W. Freethey and W.R. Meyer, written commun., 1982; unpublished data from the files of Tucson Water, City of Tucson). In a model developed by the Regional Aquifer-System Analysis program (RASA) of the U.S. Geological Survey, estimates of transmissivity range from less than 18 to $40,300 \mathrm{ft}^{2} / \mathrm{d}$ in the layer corresponding to the upper Tinaja beds and lower basin fill (T.W. Anderson and G.W. Freethey, U.S. Geological Survey, written commun., 1990). Estimates of hydraulic conductivity range from 3.4 to $716 \mathrm{ft} / \mathrm{d}$ in the Fort Lowell Formation layer. For an analog-model study of ground-water flow in the Tucson basin, Anderson (1972) estimated composite transmissivities of the lower and upper alluvium in a range from 600 to $25,000 \mathrm{ft}^{2} / \mathrm{d}$ throughout most of the basin with some values in excess of $50,000 \mathrm{ft}^{2} / \mathrm{d}$ along the Santa Cruz River. Particle-size data from wells indicate a nonlinear decrease in mean hydraulic conductivity from 140 to $20 \mathrm{ft} / \mathrm{d}$ with a 40 -percent increase in silt and clay for sediments in the Fort Lowell Formation and a nonlinear decrease from 110 to $1 \mathrm{ft} / \mathrm{d}$ with a 60-percent increase in silt and clay for the Tinaja beds (Anderson and others, 1990, fig. 9).

Storage properties of the aquifer differ from place to place and are difficult to determine because of the predominance of single-well aquifer tests and generally poor test conditions. Estimates of aquifer-storage properties are average values determined from water-budget calculations and model calibrations. Estimates of specific yield in the upper part of the aquifer can range between 0.03 and 0.25 with an average value between 0.12 and 0.15 (Anderson, 1972; Davidson, 1973; Freethey, 1986; Anderson and others, 1990). Storage coefficients of water stored below $1,000 \mathrm{ft}$ probably average about $1 \times 10^{-4}$. The total volume of recoverable water stored in the aquifer under predevelopment conditions is estimated to be 52 million acre-ft (Davidson, 1973; Freethey and Anderson, 1986).

\section{Ground-Water Development}

Ground water in the part of the upper Santa Cruz basin in Pima County is withdrawn for livestock, domestic, industrial, municipal, and agricultural uses. Before 1977, the principal use of ground water was for irrigation of crops. The first agricultural wells were completed before 1900 , but the quantity of water used did not become significant until after 1920 . From 1920 through 1939 , total pumpage was relatively uniform and averaged about 34,000 acre-ft/yr; from 1936 through 1939, pumpage averaged about 47,000 acre-ft/yr. In 1940 , pumpage was 48,300 acre-ft and the aquifer system probably was in a new state of dynamic equilibrium with generally constant water levels at a new lower level. After 1940 , pumpage generally increased steadily and was about 170,000 acre-ft in 1954 (fig. 5). During the next 13 years in Pima County, pumpage decreased and increased several times before another generally uniform increase started in 1968 and reached a maximum of about 269,000 acre- $\mathrm{ft}$ in 1975. Annual pumpage generally decreased to 195,000 acre-ft by 1986 (fig. 5). Of the total 
Table 1. Summary of estimated ground-water flow components for the upper Santa Cruz basin

[Rates are in acre-feet per year. Dashes indicate that component was not applicable to study]

\begin{tabular}{|c|c|c|c|c|c|c|c|c|c|c|}
\hline \multirow[b]{2}{*}{$\begin{array}{c}\text { Time } \\
\text { period }\end{array}$} & \multirow[b]{2}{*}{ Source } & \multicolumn{5}{|c|}{ Inflow } & \multicolumn{4}{|c|}{ Outflow } \\
\hline & & $\begin{array}{c}\text { Mountaln- } \\
\text { front } \\
\text { recharge }\end{array}$ & $\begin{array}{l}\text { Stream- } \\
\text { flow } \\
\text { Infil- } \\
\text { tratton }\end{array}$ & $\begin{array}{l}\text { Under- } \\
\text { flow } 1\end{array}$ & $\begin{array}{c}\text { Additional } \\
\text { recharge } \\
\text { or reduced } \\
\text { pumpage }\end{array}$ & Total $^{3}$ & $\begin{array}{c}\text { Evapo- } \\
\text { trans- } \\
\text { pira- } \\
\text { tlon }\end{array}$ & $\begin{array}{l}\text { Under- } \\
\text { flow }\end{array}$ & $\begin{array}{l}\text { Estimated } \\
\text { pumpage }\end{array}$ & Total $^{3}$ \\
\hline \multicolumn{11}{|c|}{ Predevelopment } \\
\hline 1940 & $\begin{array}{l}\text { Moosburner } \\
\text { (1972) }\end{array}$ & -........ & - & -......... & --_--- & - -.----.- & - & 413,000 & -------- & -.......... \\
\hline $1940-65$ & $\begin{array}{c}\text { Anderson } \\
(1972)\end{array}$ & ${ }^{4} 28,000$ & $\begin{array}{l}{ }_{4}^{4} 19,000 \\
{ }_{5} 50,930\end{array}$ & $\frac{{ }^{4} 10,000}{7,800}$ & $\left({ }^{6}\right)$ & 64,800 & $\begin{array}{c}(6) \\
5_{31,930}\end{array}$ & ${ }^{4} 17,500$ & 47,500 & 65,000 \\
\hline 1940 & $\begin{array}{l}\text { Turner and } \\
\text { others }(1943)^{7}\end{array}$ & 7 & ${ }^{8} 61,000$ & 1,000 & ${ }^{9} 7,500$ & 69,500 & ${ }^{10} 15,000$ & $\begin{array}{l}3,000 \\
4,000\end{array}$ & 78,000 & 97,000 \\
\hline pre-1900 & $\begin{array}{l}\text { Freethey and } \\
\text { Anderson } \\
(1986)^{7}\end{array}$ & ${ }^{11} 56,300$ & --o-n- & ${ }^{12} 2,300$ & 0 & 61,800 & $\frac{55,700}{{ }^{13} 3,500}$ & 6,400 & $\left({ }^{6}\right)$ & 62,100 \\
\hline $1936-65$ & $\begin{array}{l}\text { Osterkamp } \\
\text { (1973) }\end{array}$ & $\frac{4,15}{(31,900)}$ & ${ }^{14,1677,520} \frac{73,020}{6}$ & -...... & -...... & 94,920 & -..--..- & -..--..-- & --.-- & -..--- \\
\hline 1940 & Whallon (1983) & -..---.-- & ------ & ---.-...- & -..-..- & 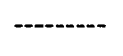 & -..--.-- & 20,100 & -.....-.- & - \\
\hline 1940 & Clifton (1981) & ----.-- & ------- & ------- & -----.- & ------- & ------- & 11,450 & - & ----.--- \\
\hline $1940-84$ & $\begin{array}{l}\text { Hanson and } \\
\text { others } \\
(1990)\end{array}$ & - & - & --.---- & - & 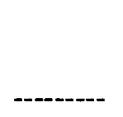 & 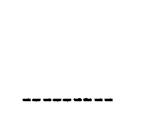 & 9,000 & --.--_-_-_- & 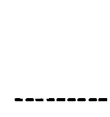 \\
\hline 1940 & $\begin{array}{l}\text { Steady-state } \\
\text { model }^{17}\end{array}$ & 29,840 & 34,020 & $\frac{7,500}{5,430}$ & - & 76,790 & 7,890 & 15,260 & 53,000 & 76,150 \\
\hline
\end{tabular}

${ }^{1}$ Top number is inflow from the south boundary along the Santa Cruz River, and bottom number is inflow from the north boundary along Cañada del Oro. A single number represents total inflow as ground-water underflow.

${ }^{2}$ Includes streamflow infiltration, irrigation return flow, sewage-effluent return flow, and industrial return flow.

3 Total of estimated inflow or outflow value used by investigator.

4 Simulated value.

5 The value of 50,930 acre-feet per year (Burkham, 1970) was considered an upper limit to streamflow infiltration. The 31,930 acre-feet per year difference between streamflow loss and infiltration may be related to unmeasured evapotranspiration or to the difference between actual and modeled hydrologic parameters used.

6 Budget component was either not estimated or not simulated by investigator or was considered negligible.

7 This study designated the basin boundary as extending to the international boundary. Values from these studies may not be directly comparable to this study. All other studies use basin boundaries that either are similar or are within the boundary of this study.

${ }^{8}$ Streamflow loss calculated for 1941. Tumer and others (1943) estimated that 90,000 acre-feet per year was a more representative average historical value. Neither value accounts for depletion by evapotranspiration during percolation.

9 Irrigation return flow.

${ }^{10}$ Evapotranspiration from ground-water reservoir only.

11 Estimate includes mountain-front recharge and streamflow infiltration from runoff.

12 Value includes underflow from Davidson Canyon area.

13 Estimate represents stream base flow only prior to channelization.

14 Top number is value for upper Santa Cruz basin using investigator's basin boundaries. Bottom number is resolved value calculated for present study boundaries.

15 Values based on Anderson (1972)

16 Values based on Burkham (1970).

17 This report. 
Table 1. Summary of estimated ground-water flow components for the upper Santa Cruz basin-Continued

\begin{tabular}{|c|c|c|c|c|c|c|c|c|c|c|}
\hline \multirow[b]{2}{*}{$\begin{array}{l}\text { Time } \\
\text { period }\end{array}$} & \multirow[b]{2}{*}{ Source } & \multicolumn{5}{|c|}{ Infiow } & \multicolumn{4}{|c|}{ Outflow } \\
\hline & & $\begin{array}{c}\text { Mountain- } \\
\text { front } \\
\text { recharge }\end{array}$ & $\begin{array}{l}\text { Stream- } \\
\text { fiow } \\
\text { Infil- } \\
\text { tration }\end{array}$ & $\begin{array}{l}\text { Under- } \\
\text { flow }\end{array}$ & $\begin{array}{c}\text { Additional } \\
\text { recharge } 2 \\
\text { or reduced } \\
\text { pumpage }\end{array}$ & Totai $^{3}$ & $\begin{array}{c}\text { Evapo- } \\
\text { trans- } \\
\text { pira- } \\
\text { tion }\end{array}$ & $\begin{array}{c}\text { Under- } \\
\text { fiow }\end{array}$ & $\begin{array}{l}\text { Estimated } \\
\text { pumpage }\end{array}$ & Totai $^{3}$ \\
\hline \multicolumn{11}{|c|}{ Development } \\
\hline $1947-51$ & $\begin{array}{l}\text { Johnson } \\
\quad(1952)^{7}\end{array}$ & 65,000 & 45,000 & 1,000 & $\begin{array}{c}1810,000- \\
20,000\end{array}$ & 121,000 & 12,000 & ${ }^{19} 4,500$ & 166,000 & 182,500 \\
\hline $1940-65$ & $\begin{array}{c}\text { Anderson } \\
(1972)\end{array}$ & $(20)$ & $\begin{array}{c}219,280- \\
49,930\end{array}$ & $(20)$ & $\left({ }^{22}\right)$ & -.-.-.- & $(6)$ & $\begin{array}{c}2017,500- \\
10,000\end{array}$ & $\left({ }^{22}\right)$ & $\left({ }^{23}\right)$ \\
\hline $\begin{array}{l}1940-46 \\
1952-68\end{array}$ & $\begin{array}{l}\text { B.N. Aldridge } \\
\text { and S.G. } \\
\text { Brown } \\
\text { (written } \\
\text { commun., } \\
\text { 1971) }\end{array}$ & 50,700 & 89,200 & ---.---- & $\begin{array}{c}24,000- \\
4,000\end{array}$ & -..--..-- & $(6)$ & -..-- & -...-...- & -------- \\
\hline 1958 & $\begin{array}{l}\text { Turner } \\
\qquad(1959)^{25}\end{array}$ & $\left({ }^{6}\right)$ & 15,000 & 23,000 & -........ & -......- & $\left({ }^{6}\right)$ & 9,000 & ${ }^{26} 78,900$ & -..-- \\
\hline $1936-63$ & $\begin{array}{l}\text { Davidson } \\
\quad(1973)^{27}\end{array}$ & 1531,000 & 1651,000 & $\frac{10,000}{7,800}$ & ${ }^{28,29} 17,300$ & 117,100 & $\begin{array}{c}{ }^{30} 6,000 \\
15,000\end{array}$ & ${ }^{30} 10,000$ & ${ }^{29} 176,700$ & 202,200 \\
\hline $1970-72$ & $\begin{array}{l}\text { Brown } \\
\quad(1976)^{7}\end{array}$ & 48,100 & 77,300 & $\frac{500}{10,000)}$ & ${ }^{31} 88,200$ & 214,100 & 15,500 & 10,000 & $\frac{274,300}{248,300}$ & 273,800 \\
\hline $1960-69$ & $\begin{array}{l}\text { Travers and } \\
\text { Mock } \\
(1984)^{32}\end{array}$ & 32,020 & 19,810 & 10,575 & 18,810 & 81,215 & $\left({ }^{6}\right)$ & 6,830 & 135,300 & 142,130 \\
\hline $1970-79$ & $\begin{array}{l}\text { Travers and } \\
\text { Mock } \\
(1984)^{32}\end{array}$ & 32,150 & 19,860 & 10,575 & 31,680 & 94,265 & $(6)$ & 6,830 & 206,750 & 213,580 \\
\hline $\begin{array}{l}{ }^{18} \text { Ran } \\
19 \text { Incll } \\
{ }^{20} \text { Stor } \\
\text { in the act } \\
{ }^{21} \text { Valu } \\
\text { Simulatio } \\
\text { the groun } \\
{ }^{22} \text { Mod } \\
23 \text { Rep } \\
{ }^{24} \text { Recl } \\
{ }^{25} \text { Basi } \\
\text { the confl } \\
26 \text { Irrig } \\
27 \text { Valu } \\
28 \text { Sew } \\
29 \text { Valu } \\
30 \text { Valu } \\
31 \text { Irrig } \\
32 \text { Aver }\end{array}$ & $\begin{array}{l}\text { e results from th } \\
\text { des } 2,000 \text { acre-f } \\
\text { ge-depletion an } \\
\text { al simulation. } \\
\text { es were simulat } \\
\text { values of } 50 \text { p } \\
\text {-water reservoir } \\
\text { l values were n } \\
\text { rted pumpage m } \\
\text { arge from sewag } \\
\text { boundaries ext } \\
\text { ence of the uppe } \\
\text { tion pumpage } \\
\text { es represent the } \\
\text { ige-effluent retu } \\
\text { e for } 1965 \text { only. } \\
\text { e for early } 1960 \\
\text { tion return flow } \\
\text { aged yearly valu }\end{array}$ & $\begin{array}{l}\text { le uncertainty } \\
\text { eet per year u } \\
\text { alysis. Prede } \\
\text { Jutflow as grc } \\
\text { ted on a yea } \\
\text { ercent of Burl } \\
\text { r. } \\
\text { ot reported. } \\
\text { inus recharge } \\
\text { ge effluent; N } \\
\text { end from sou } \\
\text { r Santa Cruz } \\
\text { vas reduced to } \\
\text { mean of the y } \\
\text { m flow and in } \\
\text { s. } \\
\text {, sewage-effl } \\
\text { les. }\end{array}$ & $\begin{array}{l}\text { of percentag } \\
\text { derflow fro } \\
\text { elopment pi } \\
\text { und-water u } \\
\text { ly basis usi } \\
\text { ham's (1970 } \\
\text { and reducec } \\
\text { gales treatm } \\
\text { h border of ' } \\
\text { River and Ri } \\
\text { account for } \\
\text { durly values } \\
\text { dustrial retu } \\
\text { ent return fl }\end{array}$ & $\begin{array}{l}\text { e of appli } \\
\mathrm{m} \text { San Ra } \\
\text { impage an } \\
\text { nderflow } \\
\text { ng Burkh } \\
\text { calculati } \\
\text { pumpage } \\
\text { ent plant } \\
\text { r. } 18 \mathrm{~S} \text {. to } \\
\text { llito Creel } \\
\text { retum flo } \\
\text { for the tim } \\
\mathrm{n} \text { flow. }\end{array}$ & $\begin{array}{l}\text { ied irrigation } \\
\text { fael valley int } \\
\text { nd inflow alon } \\
\text { was assumed } \\
\text { ham's (1970) } \\
\text { ions made the } \\
\text { e. } \\
\text { (1958-64). } \\
\text { a line from t } \\
\text { k to the Tucso } \\
\text { w. } \\
\text { ne period. }\end{array}$ & $\begin{array}{l}\text { hat recharg } \\
\text { to Mexico. } \\
\text { ig boundari } \\
\text { to decrease } \\
\text { streamflow }\end{array}$ & $\begin{array}{l}\text { es the aqu } \\
\text { les were a } \\
\text { linearly } f \\
\text { loss val }\end{array}$ & $\begin{array}{l}\text { lifer. } \\
\text { ssumed con } \\
\text { rom } 1940 \text { to } \\
\text { ues as max }\end{array}$ & $\begin{array}{l}\text { stant and not } \\
\text { o } 1965 \text {. } \\
\text { cimum annua }\end{array}$ & $\begin{array}{l}\text { t included } \\
\text { al values. } \\
\text { at reached } \\
\text { is through }\end{array}$ \\
\hline
\end{tabular}




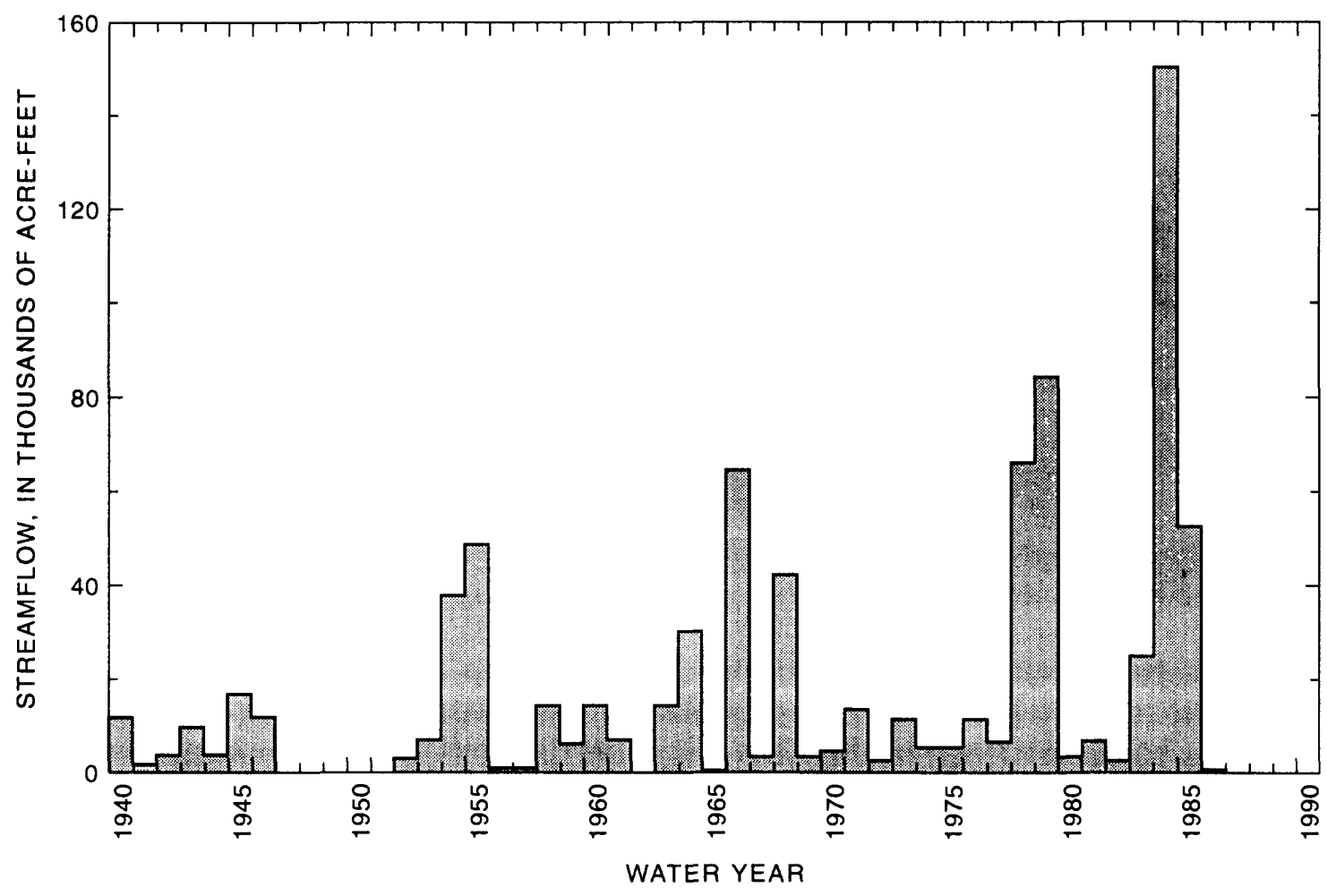

Figure 4. Annual streamflow in the Santa Cruz River at Continental, upper Santa Cruz basin, 1940-86.

reported pumpage of 195,000 acre-ft in Pima County for 1986,66 percent was public-supply use, 23 percent was agricultural use, and 11 percent was industrial use.

Total withdrawal from the aquifer for 1940-86 was 7.8 million acre- $\mathrm{ft}$ on the basis of reported pumpage values (fig. 5). For 1940-86, 52 percent of the withdrawal was for agricultural use, 33 percent was for public-supply use, and 15 percent was for industrial use. In Pima County, peak agricultural use was 140,700 acre-ft in 1954, peak industrial use was 80,200 acre- $\mathrm{ft}$ in 1980 , and peak public-supply use was 127,400 acre-ft in 1986. Ground-water withdrawals for industrial use averaged 46,000 acre-ft/yr for 1966-86. After 1982 , industrial use decreased to pre-1970 rates of less than 40,000 acre- $\mathrm{ft} / \mathrm{yr}$ as a result of reduced mining withdrawals.

Before extensive ground-water development, the hydrologic system in the upper Santa Cruz basin was in approximate equilibrium, and movement and storage of water in the aquifer were controlled by natural recharge, discharge, and lithologic relations. Ground-water pumpage in excess of recharge greatly altered the natural flow system through time. Between 1940 and 1985, water-level declines were from 100 to more than $150 \mathrm{ft}$ throughout most of north-central metropolitan Tucson (herein called the central well field, T. 14 S., R. 14 E.) and along the Santa Cruz River northeast of Black Mountain, T. 15 S., R. 13 E.; north of Sahuarita, Tps. 16 and 17 S., R. 13 E.; north of Green Valley, T. 17 S., R. 13 E.; and south of Continental, Tps. 18 and 19 S., R. 13 E. (Anderson, 1972; Babcock and others, 1987). Other effects of pumping include a shift of natural ground-water flow paths toward pumping centers, increased vertical-hydraulic gradients, development of perched ground water above the regional aquifer in areas underlain by shallow fine-grained beds, decreased transmissivity resulting from dewatering of permeable Quaternary sediments, and increased vertical effective stress resulting in compaction of the aquifer system. 
Table 2. Summary of estimated mountain-front recharge for the mountains surrounding the upper Santa Cruz basin [Rates are in acre-feet per year per mile. Dashes indicate that value was not estimated. <, less than]

\begin{tabular}{|c|c|c|c|c|c|c|c|c|}
\hline \multirow[b]{2}{*}{ Source } & \multicolumn{8}{|c|}{ Mountain-front recharge } \\
\hline & $\begin{array}{l}\text { Tortolita } \\
\text { Mins. }\end{array}$ & $\begin{array}{l}\text { Santa Catalina } \\
\text { Mtns. }{ }^{1}\end{array}$ & $\begin{array}{l}\text { Tanque Verde } \\
\text { Mtns. }\end{array}$ & $\begin{array}{l}\text { Rincon } \\
\text { Mtns. }\end{array}$ & $\begin{array}{l}\text { Santa Rita } \\
\text { Mtns. }^{2}\end{array}$ & $\begin{array}{l}\text { Tumacacori } \\
\text { Mtns. }\end{array}$ & $\begin{array}{l}\text { Slerrita } \\
\text { Mtns. }\end{array}$ & $\begin{array}{l}\text { Tucson } \\
\text { Mtns. }\end{array}$ \\
\hline Anderson $(1972)^{3} \ldots \ldots$ & 200 & $\frac{325}{180}$ & 180 & 300 & 285 & 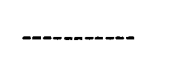 & 200 & 0 \\
\hline Davidson $(1973)^{4} \ldots \ldots . .$. & 200 & $5 \frac{325}{460}$ & 180 & 300 & 285 & ---------- & 200 & 0 \\
\hline Osterkamp $(1973)^{6,7} \ldots$ & $\begin{array}{c}270 \\
(200-400)\end{array}$ & $\frac{340}{140} \frac{200-400}{(100-200)}$ & $\begin{array}{c}250 \\
(200-400)\end{array}$ & $\begin{array}{c}250 \\
(200-400)\end{array}$ & $\frac{270}{(100-400)}$ & $\begin{array}{c}110 \\
(100-200)\end{array}$ & $\begin{array}{c}230 \\
(100-400)\end{array}$ & $\begin{array}{c}5 \\
(0-50)\end{array}$ \\
\hline Williams $(1987)^{8}$........... & --.-- & - & --------- & --------- & 285 & -------.--.- & 200 & ---o-n-- \\
\hline $\begin{array}{l}\text { Travers and } \\
\text { Mock (1984)................ }\end{array}$ & 80 & $\frac{305}{270}$ & 310 & 290 & 240 & 90 & 150 & 0 \\
\hline Mohrbacher $(1984)^{9} \ldots$ & -.----.-- & ${ }^{10} 24-65$ & - n-_-- & -------- & --.-- & -.-.-- & --.----- & - \\
\hline Belan $(1972)^{9,11} \ldots \ldots \ldots$ & -.---.--.-- & 50 & 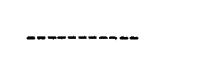 & 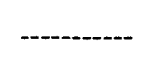 & --.---- & -- & -...-- & (n) \\
\hline Olsen $(1982)^{9} \ldots \ldots \ldots . . . . . .$. & $1-1$ & 1250 & -...- & -...- & -..-- & -..-- & -......- & -..--.-- \\
\hline $\operatorname{Merz}(1985)^{9} \ldots \ldots \ldots \ldots$ & -----.-- & 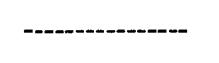 & --------- & --------- & $200-400$ & ----- & ------- & 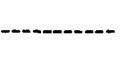 \\
\hline Thome (1983)................... & - - & - & ---------- & ----------- & ------- & --.-- & -.----- & $<20$ \\
\hline This study ${ }^{13,14}$ & $\begin{array}{l}188[1] \\
(2,258)\end{array}$ & $\begin{array}{l}175[2] \\
(3,837) \\
161[3] \\
(1,448)\end{array}$ & $\begin{array}{l}195[4] \\
(1,564)\end{array}$ & $\begin{array}{l}281[5] \\
(1,969)\end{array}$ & $\begin{array}{l}255[6] \\
\frac{(2,809)}{285[7]} \\
\frac{(4,561)}{168[8]} \\
(3,367)\end{array}$ & $\begin{array}{l}129[9] \\
(3,873)\end{array}$ & $\begin{array}{l}153[10] \\
(3,830)\end{array}$ & $\begin{array}{r}19[11] \\
(326)\end{array}$ \\
\hline
\end{tabular}

\footnotetext{
${ }^{1}$ Top value is for the values west of Sabino Creek. Bottom value is for the values east of Sabino Creek.

${ }^{2}$ Top value is for the values north of model row 42 for Santa Rita and Empire Mountains. Middle value is for the values north of model row 53 for northwestem Santa Rita Mountains. Bottom value is for the values south of model row 52 for western Santa Rita Mountains.

${ }^{3}$ Values used in electrical-analog simulation.

${ }^{4}$ Values from Anderson (1972).

${ }^{5}$ An estimated 140 acre-feet per year per mile depleted by evapotranspiration.

${ }^{6}$ Values based on Anderson (1972) and correlations of recharge with precipitation and drainage area in other areas of southem Arizona.

${ }^{7}$ Average values determined by dividing estimate of average annual recharge along mountain front by perimeter length. Values in parenthesis represent range of estimated values along mountain front.

${ }^{8}$ Values from Anderson (1972). These estimates used as initial values for modeling a part of the upper Santa Cruz basin.

${ }^{9}$ Values estimated using flow nets and water-balance equation. Results based on data collected after 1965 for periods of less than 10 years.

${ }^{10}$ Estimate does not include underflow beneath streams flowing from mountain flanks into regional aquifer.

${ }^{11}$ Belan (1972) considered mountain-front recharge in his study area to be significant only along shoestring aquifers carved in low permeability sediments.

${ }_{12}$ Study area includes a part of the Tanque Verde Mountains.

${ }^{13}$ These are average values for the entire mountain front; actual values vary from cell to cell. Value in parenthesis is total simulated recharge for specified mountain front.

${ }^{14}$ Number in bracket is reach identifier shown in figure 7.
} 


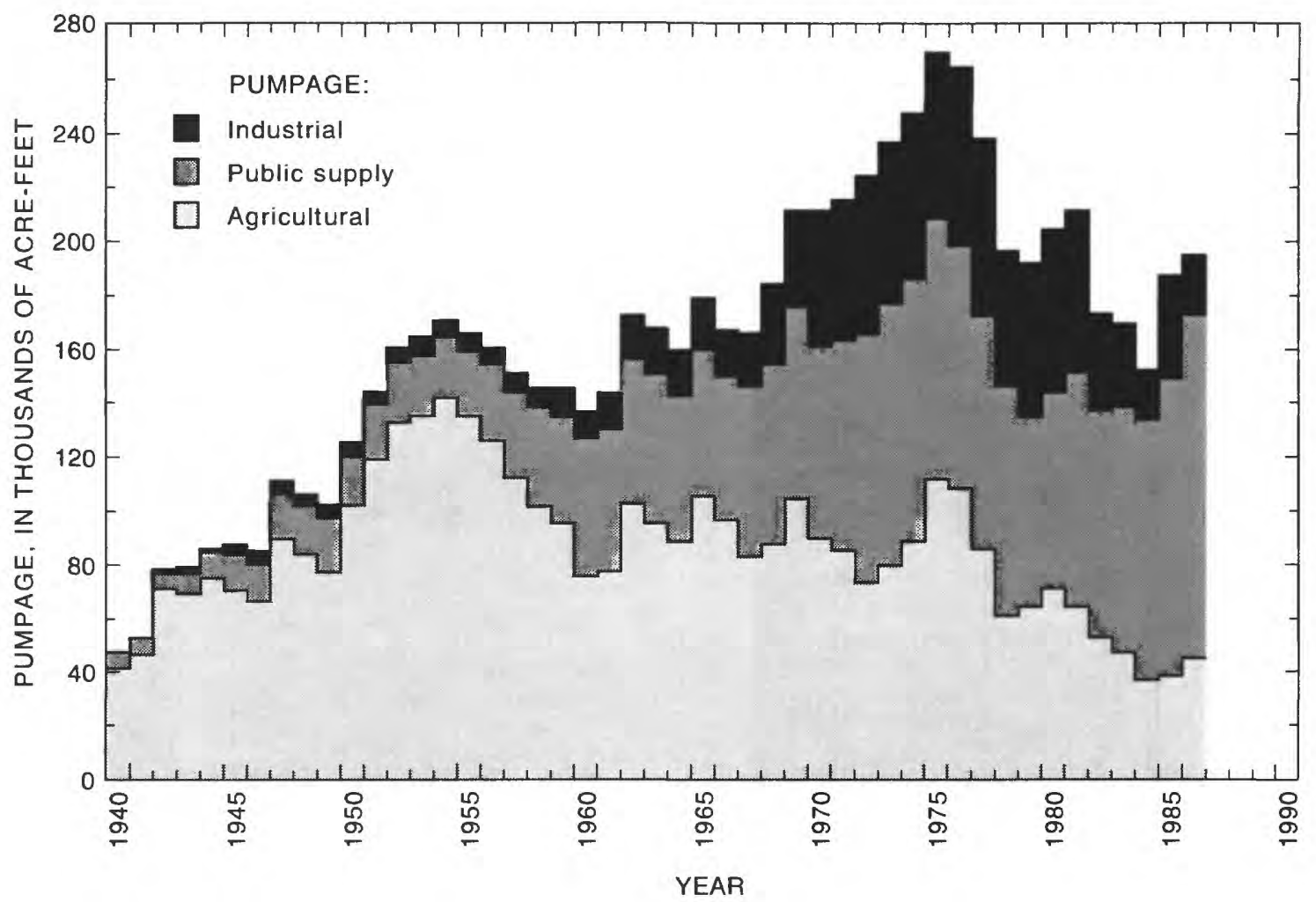

Figure 5. Annual reported ground-water pumpage in the part of the upper Santa Cruz basin in Pima County, 1940-86.

\section{SIMULATION OF GROUND-WATER FLOW}

A numerical ground-water flow model of the upper Santa Cruz basin was developed to simulate steady-state conditions for 1940 and transient-state conditions for 1940-86 in the aquifer system. Model results provided information concerning predevelopment hydrologic conditions and response of the aquifer system to changes in pumping and recharge through time. Simulations were made using a three-dimensional finitedifference ground-water flow model developed by McDonald and Harbaugh (1988). Transient-state simulations were calibrated for 1941 through 1986. A sensitivity analysis was used to evaluate the sensitivity of simulated heads to changes in hydraulic parameters. Model results and calibration also provided insight into the limitations and need for future refinements of this regional-scale model.
Previous models include basin-wide electricalanalog (Anderson, 1972) and digital models (T.W. Anderson and G.W. Freethey, U.S. Geological Survey, written commun., 1990) and subregional flow models (Fogg, 1978; Williams, 1987). A twolayer model developed by the RASA Project was the initial framework used by this study (T.W. Anderson and G.W. Freethey, U.S. Geological Survey, written commun., 1990). The stratigraphic basis for layering and the distributions of hydraulic conductivity and transmissivity used by the RASA model (G.W. Freethey and W.R. Meyer, U.S. Geological Survey, written commun., 1982) were used for this model. The upper layer used by the RASA model does not include the upper Tinaja beds, which represent the base of the upper alluvium. The upper layer is coincident with the saturated areal extent of the Fort Lowell Formation and the shallow depths of most early wells. Relayering and redistribution of aquifer parameters were beyond the scope of this study but could be evaluated in future refinements of the regional 
ground-water flow model. An active flow region in the upper layer of $379 \mathrm{mi}^{2}$ (fig. 6) represents the saturated part of the stream alluvium and the Fort Lowell Formation within the regional upper alluvium in 1979. An active flow region in the lower layer of $847 \mathrm{mi}^{2}$ (fig. 6) represents the saturated part of the upper Tinaja beds within the regional upper alluvium and the Pantano Formation and the lower and middle Tinaja beds within the lower alluvium in 1979 (fig. 3). The model was discretized with uniform grid spacing of $1 \mathrm{mi}^{2}$ (fig. 6).

Constant-head ground-water inflow and outflow cells were specified at the model boundaries for the steady-state simulation along the Santa Cruz River, and constant flow cells were used at the model boundaries along Cañada del Oro. On the basis of fairly constant measurements of water levels at the inflow boundary along the Santa Cruz River, ground-water inflow was specified as headdependent cells with constant boundary heads through time for transient-state simulations (fig. 6). The ground-water outflow near Rillito also was represented as a head-dependent boundary for transient simulations. These boundary heads were varied through time because of water-level declines in adjacent Avra Valley. Ground-water inflow of 5,430 acre-ft/yr from Cañada del Oro was held constant for predevelopment and varied through time as a general-head boundary for transient-state simulation. All mountain-front recharge was simulated as a relatively uniform constant inflow in boundary cells coincident with minor tributaries for steady- and transient-state simulations (table 2 and fig. 7). All streamflow infiltration was simulated by constant inflow along nine reaches for steadyand transient-state simulations (table 3, fig. 6). No-flow boundaries were specified for all other boundary cells.

Hydraulic conductivity of layer 1, transmissivity of layer 2, storage properties for both layers, and vertical leakance between layers were specified for the model. Transmissivity of layer 1 was calculated by the model using modelcalculated saturated thickness and specified hydraulic conductivity. Transmissivity of layer 2 was specified directly in the model and remained constant, thus assuming that no significant changes in saturated thickness or hydraulic conductivity occurred during the simulated period of historical development. Storage was simulated by specifying specific yield in layer 1 and storage coefficient in layer 2. The bottom altitude of the upper layer was estimated from the hydrogeologic studies of Davidson (1973) and Anderson (1987, 1988). Vertical flow between layers was simulated by the RASA models of southeastern alluvial basins with a typical leakance value of about $10^{-2}(\mathrm{ft} / \mathrm{d}) / \mathrm{ft}$ and a range of 10 to $10^{-6}(\mathrm{ft} / \mathrm{d}) / \mathrm{ft}$ (Freethey, 1986). The RASA model for the Tucson basin used a uniform leakance value of $1.0 \times 10^{-6}(\mathrm{ft} / \mathrm{s}) / \mathrm{ft}(0.0014(\mathrm{ft} / \mathrm{d}) / \mathrm{ft})$ that did not maintain saturated cells for the 1979 extent of saturated thickness of the Fort Lowell Formation. During steady-state calibration of the model developed in this study, the leakance was reduced to $1.0 \times 10^{-7}(\mathrm{ft} / \mathrm{s}) / \mathrm{ft}(0.0086(\mathrm{ft} / \mathrm{d}) / \mathrm{ft})$ and was indexed on clay-and-silt content with an integer multiplier 1,2,3, and 4 for each of the textured subregions of the Fort Lowell Formation (fig. 8). Thus, cells with 60 to 80 percent silt and clay were assigned a value of $1 \times 10^{-7}(\mathrm{ft} / \mathrm{s}) / \mathrm{ft}(0.0086(\mathrm{ft} / \mathrm{d}) / \mathrm{ft})$ and cells with less than 20 percent silt and clay were assigned a value of $4 \times 10^{-7}(\mathrm{ft} / \mathrm{s}) / \mathrm{ft}(0.035(\mathrm{ft} / \mathrm{d}) / \mathrm{ft})$. The resulting vertical leakance between layers ranged from $3.5 \times 10^{-2}$ to $8.6 \times 10^{-3}(\mathrm{ft} / \mathrm{d}) / \mathrm{ft}$. These vertical leakance values are comparable to the range of estimated values $-9 \times 10^{-2}$ to $9 \times 10^{-4}(\mathrm{ft} / \mathrm{d}) / \mathrm{ft}$-used in the adjacent Avra Valley ground-water flow model (Hanson and others, 1990).

Steady-state and transient-state simulations were calibrated to measured water levels, contours of measured water levels, and contours of waterlevel changes that generally represent average conditions in the upper $1,000 \mathrm{ft}$ of the aquifer (model layers 1 and 2). Simulated water levels were bilinearly interpolated to the locations of measured water levels for point comparisons of calibration error. Hydrographs showing point comparisons through time also were used for transient-state model comparisons. Most hydrograph data used for transient comparisons are from index wells used by the Arizona Department of Water Resources (Murphy and Hedley, 1984) and the City of Tucson (Babcock and others, 1987) to monitor the aquifer system in the upper Santa Cruz basin. 

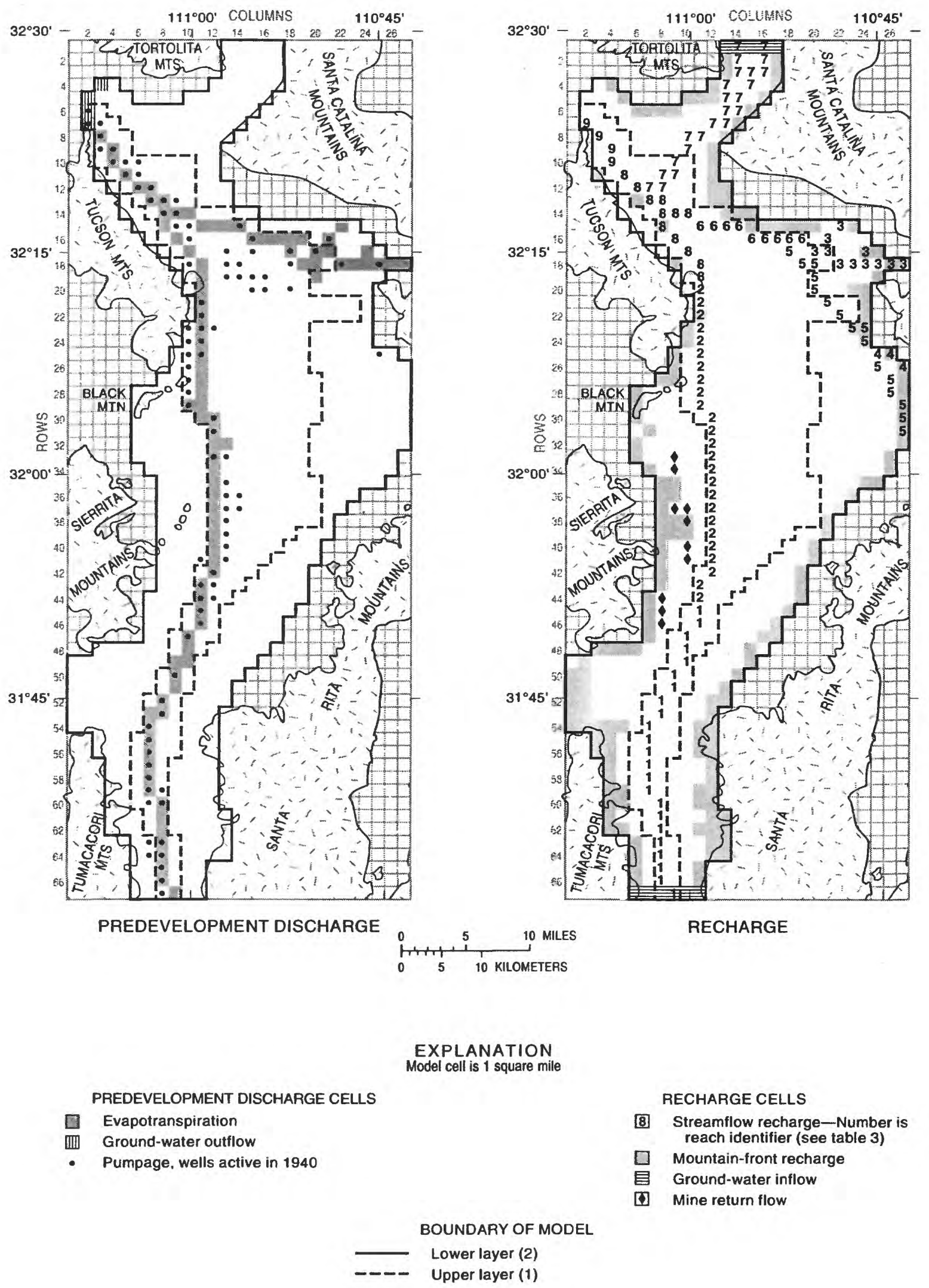

Figure 6. Finite-difference grid with boundary conditions for layers 1 and 2 of the upper Santa Cruz basin ground-water model. 


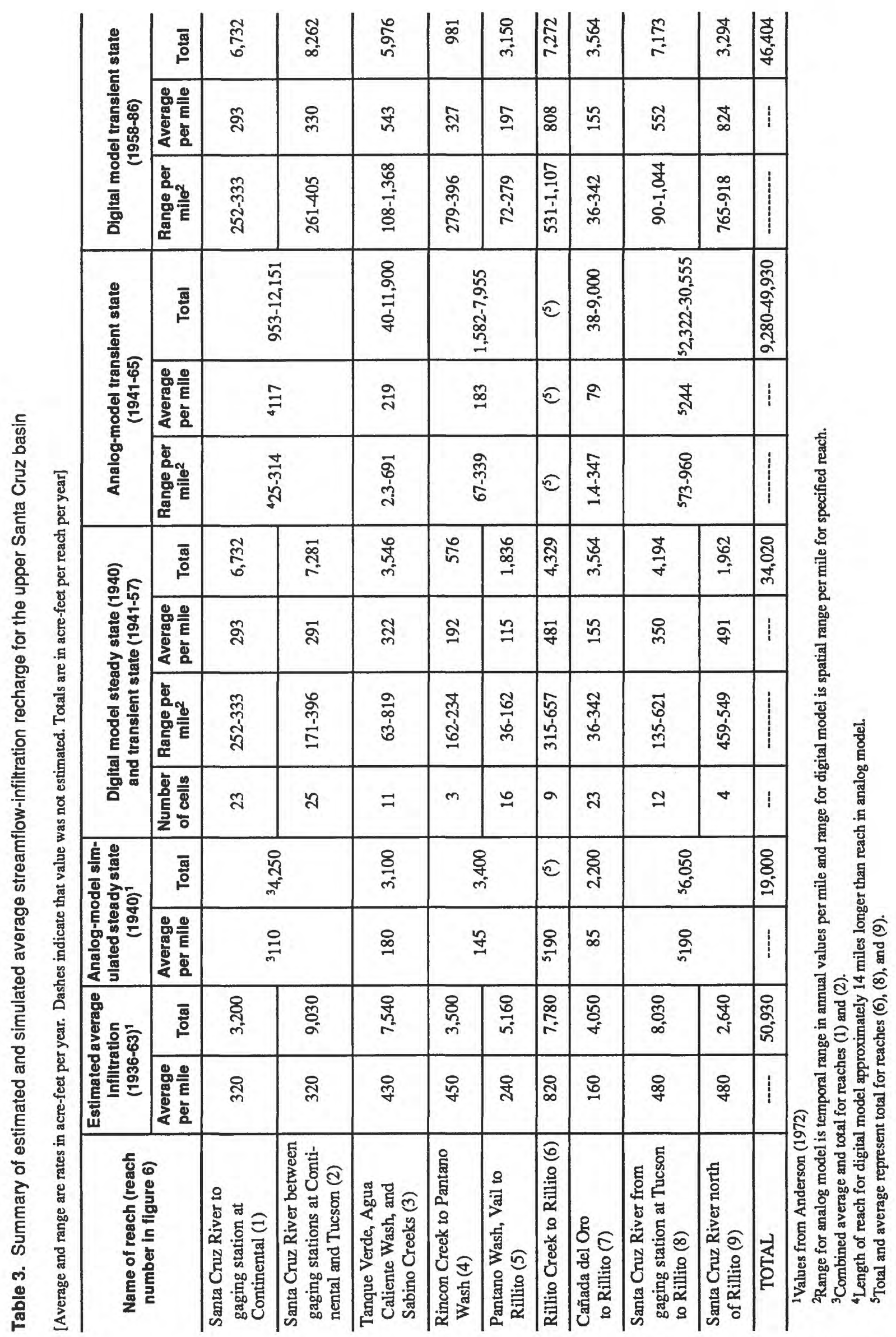




\section{Steady-State Simulation}

Simulation of ground-water flow in 1940 allowed for evaluation of steady-state conditions in the aquifer before extensive ground-water development. Simulation of predevelopment conditions in 1940 results in a steady-state model during a period of dynamic equilibrium when only about 3 percent of the basin was affected by waterlevel declines from early pumpage (Anderson, 1972), and when there were numerous water-level measurements needed for model comparison. This steady-state simulation assumes that no change in storage occurs and that inflow is equal to outflow. Model calibration started with analog-model estimates (Anderson, 1972) of steady-state inflow and outflow and estimates of hydraulic conductivity and transmissivity from the RASA model. The calibration required agreement between measured and simulated heads and estimated and simulated inflow and outflow.

Computed inflow and outflow balanced within about 0.01 percent and were, in part, similar to Anderson's (1972) previous estimates and distribution of flow (table 1). This simulation, like Anderson's (1972), required mountain-front recharge and streamflow infiltration (table 1) as well as ground-water inflow for satisfactory calibration. Outflow components included predevelopment pumpage, evapotranspiration, and underflow out of the basin to Avra Valley (table 1). Unlike previous flow models (Anderson, 1972; Travers and Mock, 1984), evapotranspiration was explicitly simulated.

About 39 percent of the total computed inflow of 76,790 acre-ft/yr, or $29,840 \mathrm{acre}-\mathrm{ft} / \mathrm{yr}$, entered the basin as mountain-front recharge. The initial estimate and distribution of mountain-front recharge was based mainly on previous estimates (fig. 7, tables 1 and 2). Time-averaged estimates of mountain-front recharge were represented as constant-flow cells. Minor adjustments in rate and redistribution to cells that were aligned with minor ungaged tributaries were made in matching predevelopment water levels during calibration. The largest amounts of recharge were simulated along the Catalina, Santa Rita, Sierrita, and Tumacacori Mountains (fig. 7 and table 2). The largest average rates of mountain-front recharge were simulated along the Santa Rita, Rincon, and

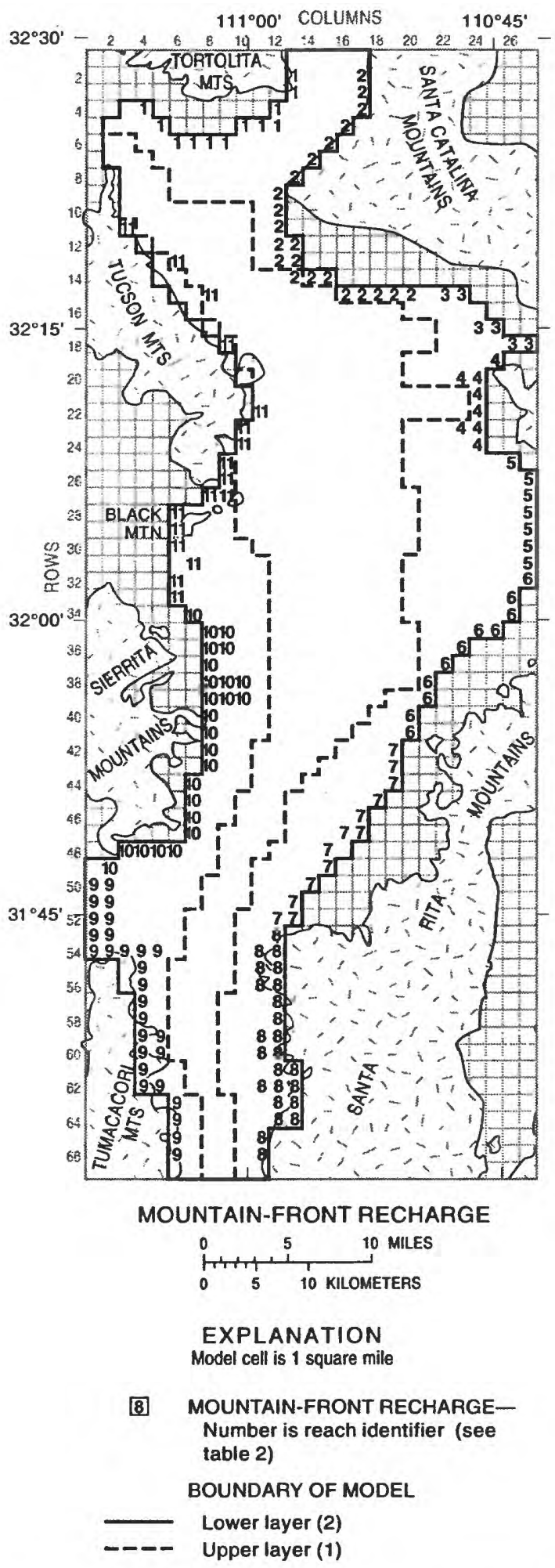

Figure 7. Finite-difference grid with mountain-front recharge for layers 1 and 2 of the upper Santa Cruz basin ground-water model. 

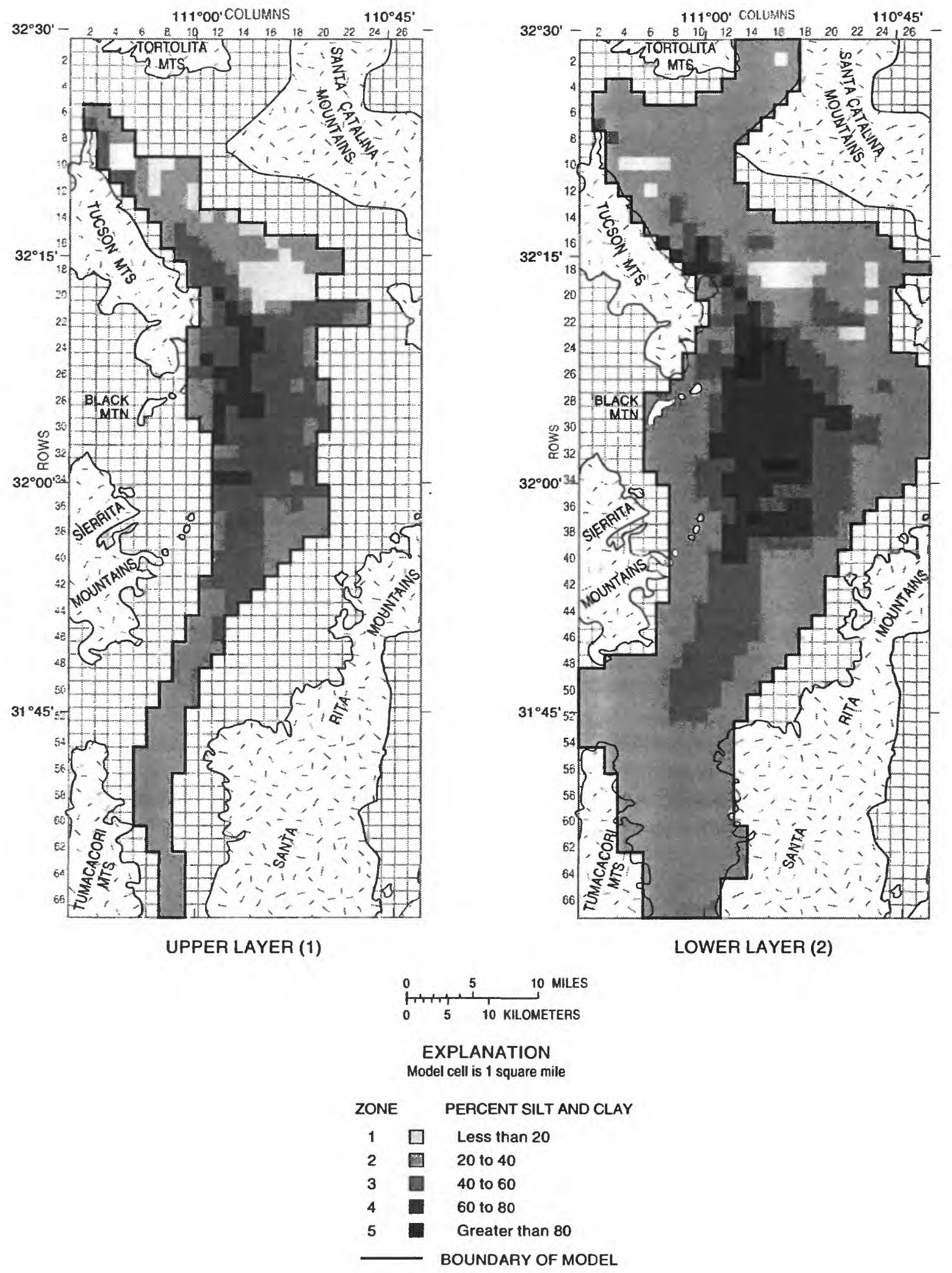

Figure 8. Finite-difference grid with average silt and clay contents for layers 1 and 2 of the upper Santa Cruz basin ground-water model. 
Tanque Verde Mountains. The simulated average rates are generally lower than Anderson's rates (1972) because of the redistribution to additional cells along ungaged tributaries. The total amount was slightly more than Anderson's total (1972) because of the small amount of additional recharge simulated along the Tucson Mountains and the additional recharge south of the analog-model boundary in Santa Cruz County (fig. 7).

About 44 percent of the total inflow, $34,020 \mathrm{acre}-\mathrm{ft} / \mathrm{yr}$, occurred as streamflow infiltration. Time-averaged estimates of tributarystreamflow infiltration were represented as constant-flow cells. The estimates for streamflow infiltration were based on the streamflowinfiltration estimates made for individual reaches (table 3 ) on the basis of average conditions for 1936-63 (Burkham, 1970, pl. 1). These values were reduced by 10 percent to account for the moisture depletion required to bring the unsaturated sediments beneath the mainly ephemeral washes to field capacity (Burkham, 1970). Subsequent calibration required that an additional reduction of 40 percent of Burkham's estimates be made along Pantano Wash, Tanque Verde Wash, Rillito Creek, and the Santa Cruz River north of the confluence with Rillito Creek (fig. 9). Reductions of 33 to 54 percent of Burkham's (1970) estimates also were made for the analog model (Anderson, 1972). The additional streamflow infiltration above Anderson's estimate (1972) used in the analog simulation is offset partly by the smaller groundwater inflow (table 3) and includes infiltration south of the analog-model boundary in Santa Cruz County. Simulated streamflow was distributed over all nine reaches (fig. 8) on a cell-by-cell basis with a constant infiltration rate, estimated stream length per cell, and required balance of inflow and outflow between reaches. This yields an average yearly inflow with a routed cell-by-cell distribution (fig. 9) that is in alignment with the relative inflows, outflows, and losses estimated by Burkham (1970).

About 17 percent of the total computed inflow occurred as underflow into the basin. Of that amount, just less than half, or 5,430 acre-ft/yr, entered the basin as underflow through Cañada del Oro and was simulated with constant-flow cells in layer 2 . This quantity represents about 70 percent of the inflow used in the analog model (Anderson, 1972). Constant-head inflow cells were used to simulate 7,500 acre- $\mathrm{ft} / \mathrm{yr}$ entering the basin as underflow south of Tubac. All the inflow through Cañada del Oro and 68 percent of the inflow near Tubac occurred in layer 2.

Outflow from the aquifer as pumpage accounted for 70 percent of the total simulated outflow. Predevelopment pumpage of 47,500 acre-ft/yr estimated and used by Anderson (1972) was distributed among cells in the uppermost active layer throughout the model area for the steady-state simulation (fig. 6). The steady-state pumping rate also includes an additional $6,860 \mathrm{acre}-\mathrm{ft} / \mathrm{yr}$ of agricultural pumpage in the part of the model in Santa Cruz County. This agricultural pumpage was estimated with an average water requirement of 3 acre-ft/yr/acre and was distributed on the basis of a 1944 survey of irrigated acreage (University of Arizona, 1944). The net predevelopment pumpage of 53,000 acre-ft/yr was used for modeling steadystate conditions, and an additional 1,360 acre- $\mathrm{ft} / \mathrm{yr}$ occurred in the constant-head cells.

Evapotranspiration accounted for about 8 percent of total outflow, or $7,890 \mathrm{acre}-\mathrm{ft} / \mathrm{yr}$, which is comparable to the minimum estimate made by Davidson (1973) of 6,000 acre-ft/yr for the mid1960 's but is less than other predevelopment estimates. Simulation of evapotranspiration was made on the basis of densities and types of vegetation observed on aerial photographs of the basin taken in 1936 and 1941. A single extinction depth of $25 \mathrm{ft}$ was assigned on the basis of published values for mesquite and cottonwood (Robinson, 1958). The potential areal distribution of evapotranspiration was determined by aerial photographs showing natural vegetation and predevelopment depth-to-water measurements that were less than $25 \mathrm{ft}$ (Smith and Schwalen, University of Arizona, written commun., 1940; Schwalen and Shaw, 1957). Consumptive-use calculations made using the Blaney-Criddle formula (Blaney and Criddle, 1949; Blaney and Harris, 1951) and Tucson climate data for 1941 (Sellers and Hill, 1974; Cruff and Thompson, 1967) were prorated to a uniform rate for a whole year and on the basis of vegetation densities. Evapotranspiration was not simulated along Cafiada del Oro because predevelopment depth-towater measurements were more than $100 \mathrm{ft}$. The distribution of potential evapotranspiration extended throughout most of the Santa Cruz River 

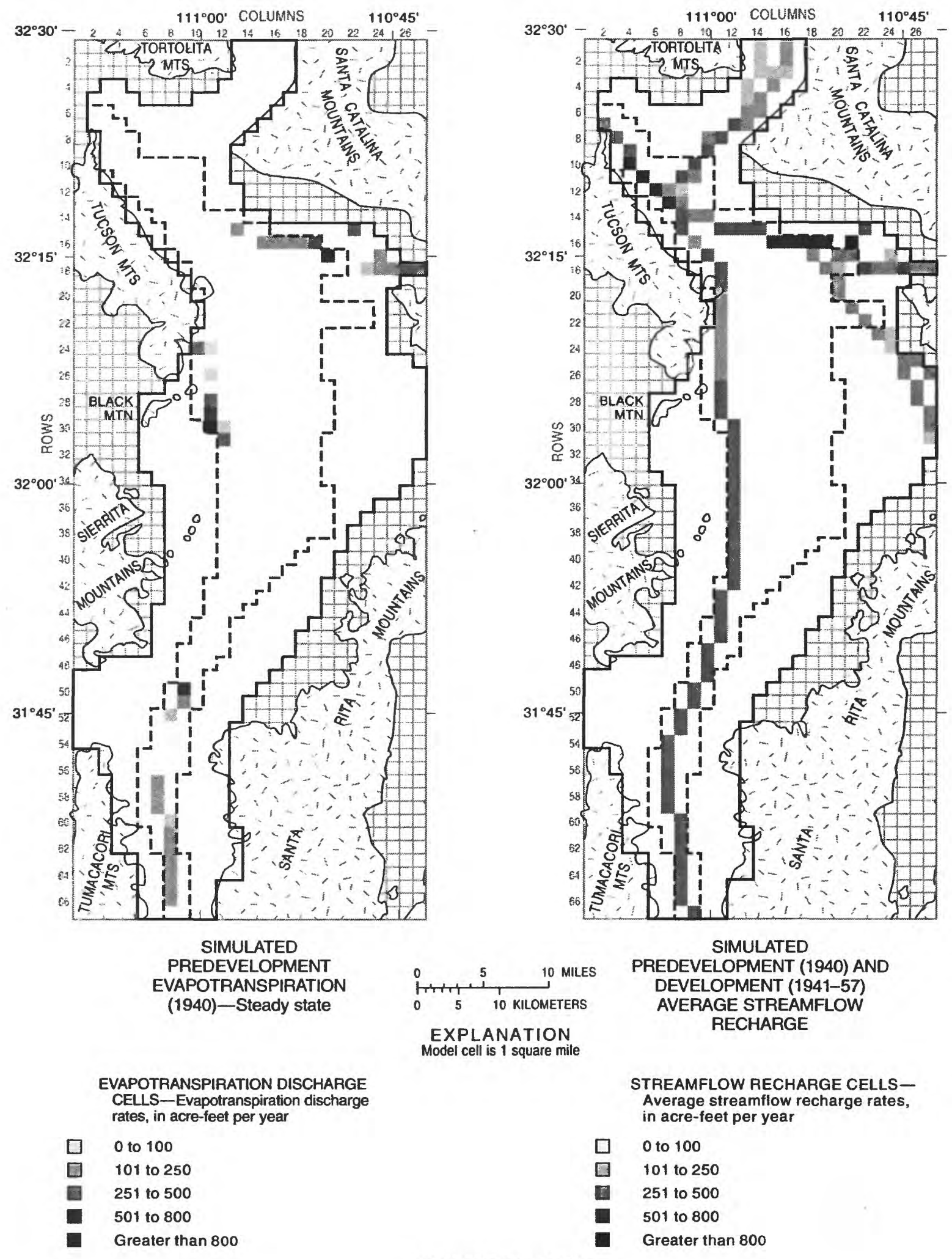

STREAMFLOW RECHARGE CELLSAverage streamfiow recharge rates. in acre-feet per year

口 0 to 100

101 to 250

251 to 500

501 to 800

Greater than 800

BOUNDARY OF MODEL

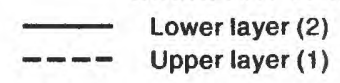

Figure 9. Simulated evapotranspiration (1940) and average streamflow recharge (1941-57) for layers 1 and 2 of the upper Santa Cruz basin ground-water model. 
and tributary flood-plain areas (fig. 6). The restriction of simulated evapotranspiration to the Santa Cruz River flood plain south of Continental and near Tucson, and to the Rillito, Sabino, and Tanque Verde Creeks (fig. 9) may be due, in part, to the presence of predevelopment pumpage.

Total simulated outflow as ground-water underflow was 15,260 acre-ft/yr near Rillito. About 85 percent of this outflow was through layer 1 . The outflow falls in the range of predevelopment estimates (table 1), is comparable to the analog model outflow (Anderson, 1972), and is about 50 percent more than the simulated inflow for the Avra Valley model (Hanson and others, 1990).

Hydraulic conductivity and transmissivity were estimated from available data and analog-model distributions. These initial estimates were adjusted during calibration to produce the final distributions of hydraulic conductivity (fig. 10) and transmissivity (fig. 11). The final hydraulicconductivity distribution ranged from 3 to $255 \mathrm{ft} / \mathrm{d}$ for layer 1 . The final transmissivity distribution ranged from 19 to $18,600 \mathrm{ft}^{2} / \mathrm{d}$ for layer 2 . Magnitude and distribution of composite transmissivity (fig. 12) are similar to those determined for the electrical-analog model developed by Anderson (1972). Final composite transmissivities ranged from 19 to $49,200 \mathrm{ft}^{2} / \mathrm{d}$.

In the calibrated steady-state model, head differences between layers 1 and 2 were less than several feet. However, some upward flow between layers was indicated by steady-state simulation throughout most of the areal extent of the upper layer. The net upward flow to layer 1 was $42,500 \mathrm{acre}-\mathrm{ft} / \mathrm{yr}$, which is about half the total simulated flow. Upward flow was greatest (35 percent of total upward flow) in the Cortaro region where the flow system is constricted between the Tucson and Santa Catalina Mountains. About 66 percent of the total simulated upward flow and 46 percent of the simulated downward flow between layers occurred on the boundary of the upper layer. This large percentage is in part a result of the model configuration that reflects vertical flow as well as some lateral flow of streamflow infiltration and mountain-front recharge across the lateral boundary of the less extensive upper layer.

The root-mean-square differences between measured and steady-state simulated (fig. 13) water levels in 73 comparisons for the upper layer and 36 comparisons in the lower layer were 11 and $16 \mathrm{ft}$, respectively. The comparison points were almost exclusively along the Santa Cruz River with additional points along Cañada del Oro and Rillito and Tanque Verde Creeks. The mean errors for the upper and lower layers were $-0.5 \mathrm{ft}$ and $-3.0 \mathrm{ft}$, respectively, with no apparent systematic error with respect to altitudes (fig. 13A). The errors are approximately normally distributed about a median value of $-1.7 \mathrm{ft}$, indicating simulated water levels slightly higher than measured values (fig. 13B). The largest overestimation of waterlevel altitudes occurred mainly along the Santa Cruz River near the southeast edge of the Tucson Mountains. Differences between contours of measured water levels and lower-layer simulated head generally ranged from 0 to $25 \mathrm{ft}$ but were as much as $60 \mathrm{ft}$ along the basin margins where the uncertainty in aquifer properties and measured water levels is the greatest (fig. 14). Water-level gradients and contour shapes matched the handcontoured water levels from Anderson (1972) with minor differences in the south-central basin (Tps. 14 and 15 S., Rs. 14 and 15 E.).

\section{Transient-State Simulation}

Simulation of ground-water flow from 1941 through 1986 allowed for evaluation of the response of the aquifer to changes in pumping and recharge through time. The transient-state simulations used estimated pumpage data, hydraulic characteristics, and simulated heads from the steady-state model for initial conditions. Calibration required matching measured and simulated heads and provided estimates of specific yield and changes in head, recharge, and water released from storage. Transient simulations included monthly time steps within eight stress periods-1941, 1942-46, $1947-49,1950,1951-52,1953-57,1958-61$, and 1962-65 - that were in alignment with the changes in reported pumpage (fig. 5) and with the stress periods used in Anderson's (1972) electrical-analog model calibration (table 4). For the remaining years of the transient simulation, 1966-86, yearly stress periods with monthly time steps were used (table 4). All pumpage data for transient simulations were distributed cell by cell in the uppermost active layer 


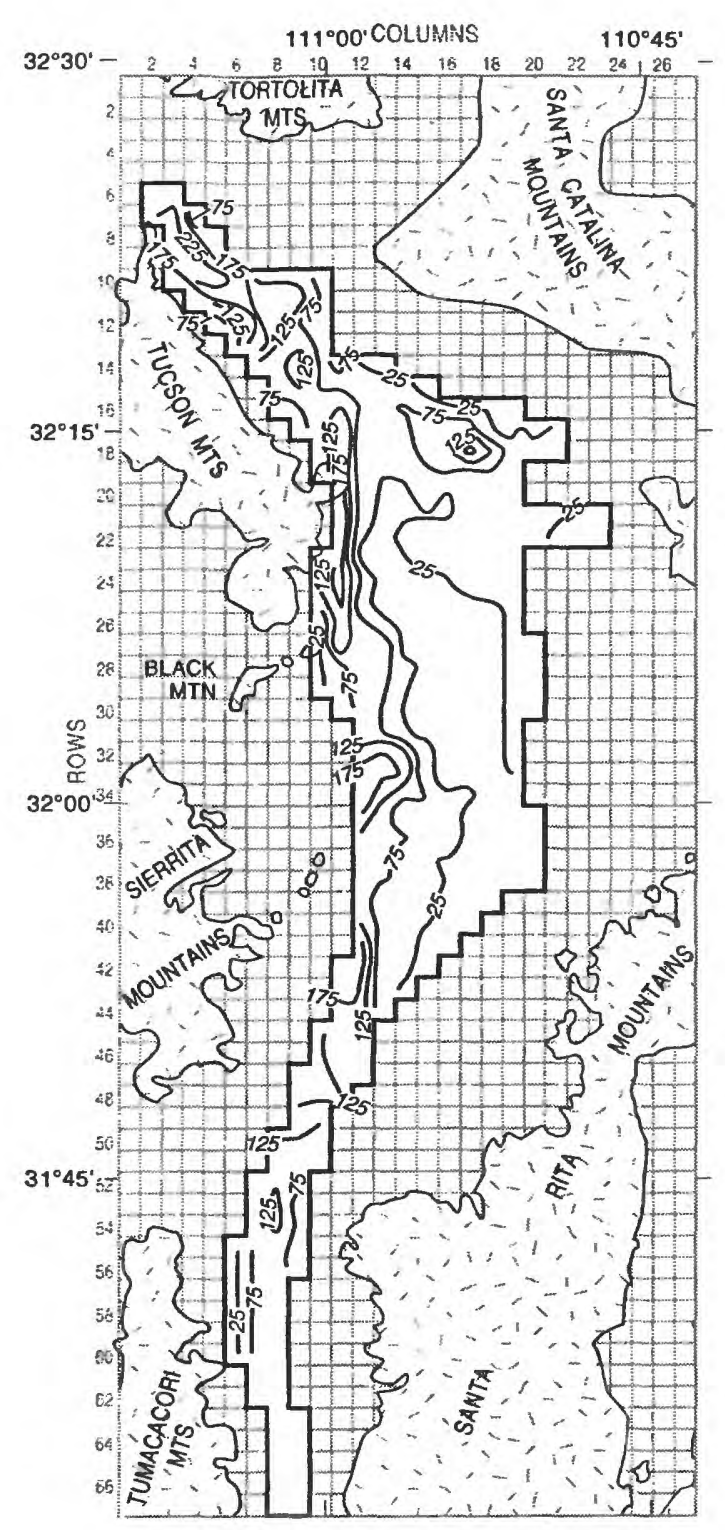

HYDRAULIC CONDUCTIVITY
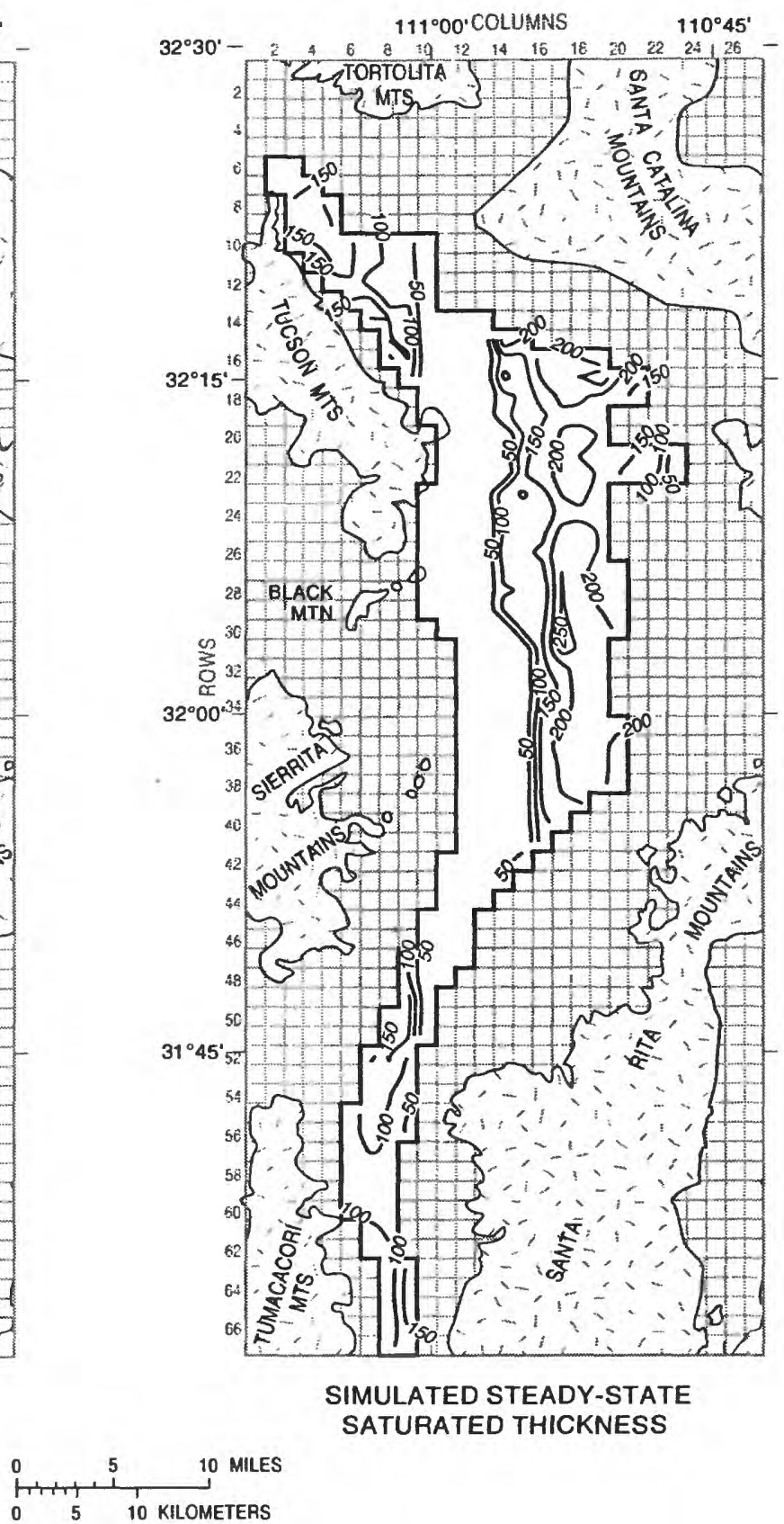

\section{EXPLANATION}

Model cell is 1 square mile

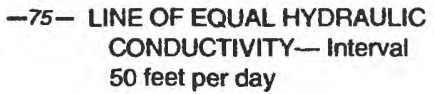
-50- LINE OF EQUAL STEADY-STATE SATURATED THICKNESS- Interval 50 feet

BOUNDARY OF MODEL

Figure 10. Hydraulic conductivity and simulated steady-state saturated thickness of model layer 1 of the upper Santa Cruz basin ground-water model. 


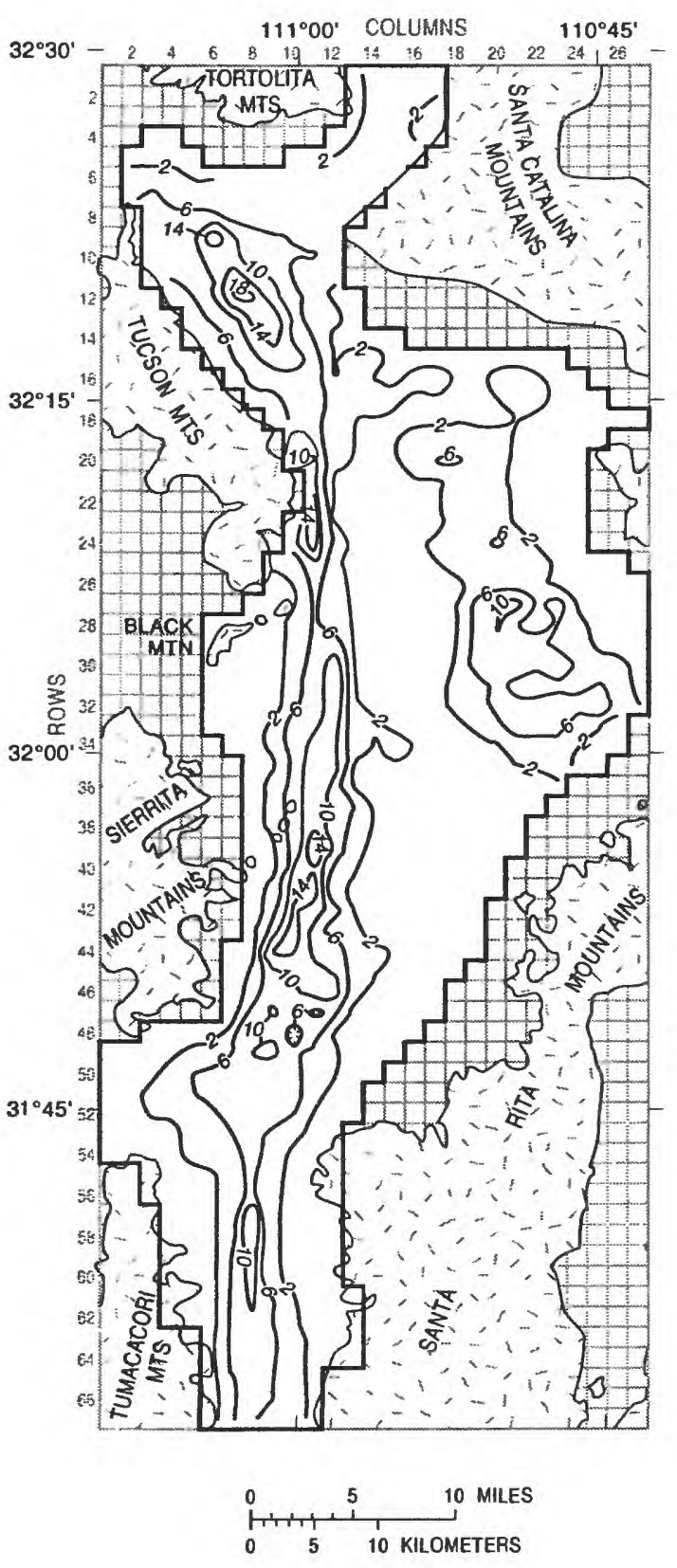

EXPLANATION

Model cell is 1 square mile

-6- LINE OF EQUAL TRANSMISSIVITYInterval in thousands of feet squared per day. Hachures indicate closed area of lower transmissivity

- BOUNDARY OF MODEL

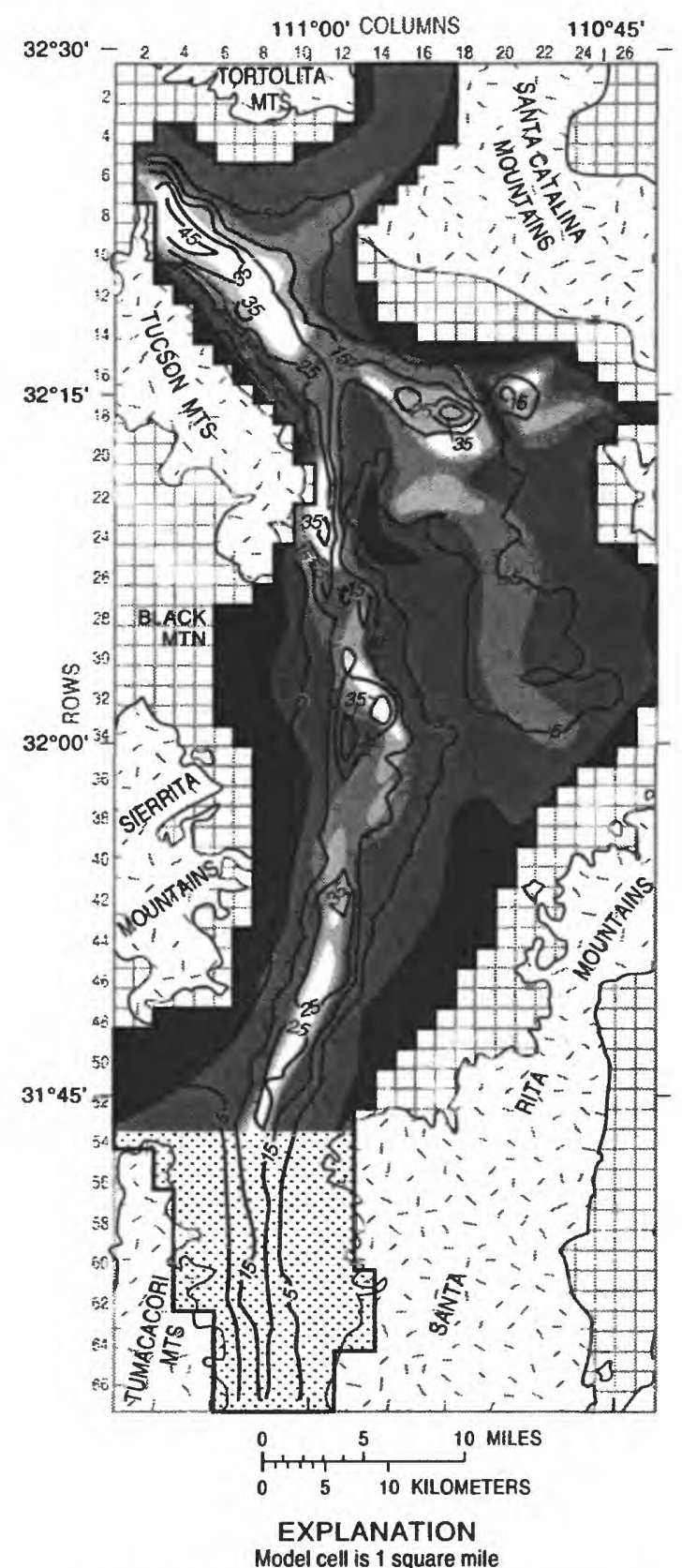

REGION OF TRANSMISSIVITY FROM ELECTRICALANALOG MODEL (ANDERSON,1972), IN FEET SQUARED PER DAY-Number in parenthesis is in gallons per day per foot

$<1,340(<10,000)$

$1,340-6,680(10,000-50,000)$

$6,680-13,370(50,000-100,000)$

$13,370-24,060(100,000-180,000)$

$>24,060(>180,000)$

Outside analog model

-15- LINE OF EQUAL COMPOSITE TRANSMISSIVITY FOR STEADY-STATE SIMULATION-Interval in thousands of feet squared per day.

BOUNDARY OF MODEL

Figure 12. Composite transmissivity of model layers 1 and 2.

Figure 11. Transmissivity of model layer 2. 

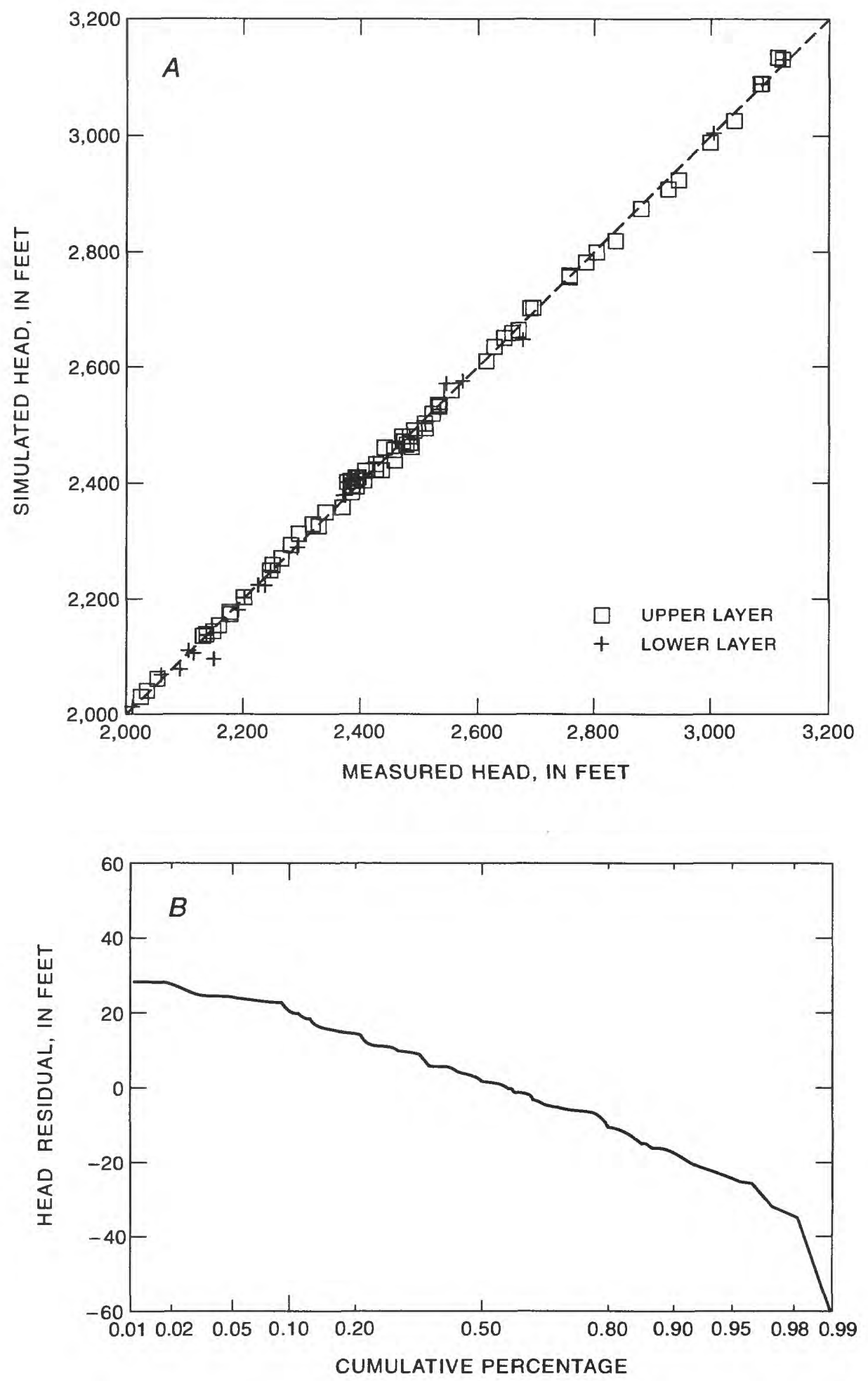

Figure 13. Distribution of predevelopment head residuals. A, Deviation of steady-state simulated heads from measured heads. $B$, Weibull probability plot of head residuals. 


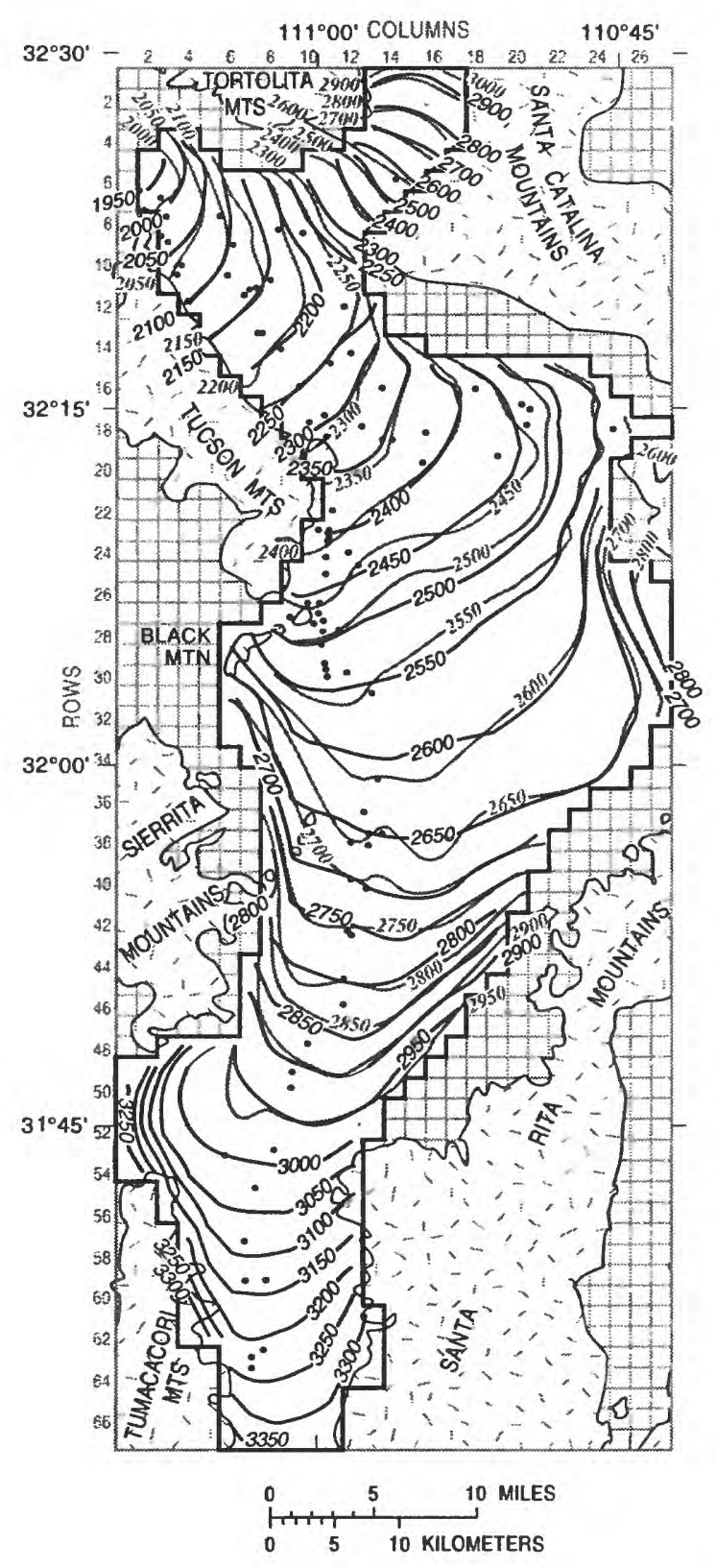

EXPLANATION

Model cell is 1 square mile

WATER-LEVEL CONTOUR, 1940

Shows altitude of water level.

Contour interval 50 feet. Datum is sea level

-2850- From measured data (Anderson, 1972)

-2850 - From simulated data

- BOUNDARY OF MODEL

- comparison WELl

Figure 14. Measured and simulated ground-water levels for model layer 2 of the upper Santa Cruz basin, 1940. on the basis of irrigated areas, power use, or direct estimates of municipal and industrial pumpage. All pumpage for 1980-86 was assigned to layer 2 to reflect substantial desaturation of the upper layer with deeper positioning of pump bowls, drilling of deeper new wells, and deepening of many existing wells throughout the basin. Mountain-front recharge was held constant for the entire transient simulation (table 4) as was done in previous models (Anderson, 1972; Travers and Mock, 1984).

Transient calibration was done over two time periods, 1940-65 and 1966-86. The first time period, which was considered to represent a storage-depletion system, used stress periods and pumpage data developed with the analog-model study and allowed for comparison with analog-model results (Anderson, 1972). The second time period was characterized by different pumpage distributions and was affected by an increase in irrigation and mine retum flow and in streamflow infiltration (1958-86). An additional transient period, 1987-2025, was included for projection of potential subsidence and is discussed in the section "Simulation of Potential Land Subsidence."

Changes in head through time at the groundwater outflow boundary were assumed to be relatively similar across the boundary on the basis of hand-contoured and simulated water levels in Avra Valley (Hanson and others, 1990). For the early part of the transient simulation, 1940-52, changes in head are based on simulated water-level changes from the Avra Valley ground-water flow model (Hanson and others, 1990, fig. 15, point J). For the rest of the transient simulation, changes in the outflow boundary head were based on the hydrograph for well (D-12-11)12bdc from the Avra Valley flow model (Hanson and others, 1990, fig. 15, well J). The conductances at the outflow boundary near Rillito were about $12,600 \mathrm{ft}^{2} / \mathrm{d}$ in layer 1 and ranged from 96 to $1,750 \mathrm{ft}^{2} / \mathrm{d}$ in layer 2 . Changes in head through time at the ground-water inflow boundary along Cañada del Oro were assumed to be linear for the early part of the transient simulation, 1940-56, and were based on the hydrograph for well (D-10-14)29dca for the remainder of the simulation. The conductances at the inflow boundary along Cafiada del Oro ranged from 450 to $2,000 \mathrm{ft}^{2} / \mathrm{d}$ in layer 2 . The conductances at the inflow boundary along the 
Table 4. Summary of transient simulated ground-water flow components for the upper Santa Cruz basin model [Rates are in acre-feet per year]

\begin{tabular}{|c|c|c|c|c|c|c|c|c|c|c|c|}
\hline \multirow[b]{2}{*}{$\begin{array}{l}\text { Time } \\
\text { perlod }\end{array}$} & \multirow[b]{2}{*}{$\begin{array}{l}\text { Stress } \\
\text { period }\end{array}$} & \multicolumn{5}{|c|}{ Inflow } & \multicolumn{5}{|c|}{ Outflow } \\
\hline & & $\begin{array}{c}\text { Mountain- } \\
\text { front } \\
\text { recharge }\end{array}$ & $\begin{array}{l}\text { Stream- } \\
\text { flow } \\
\text { infil- } \\
\text { tration }\end{array}$ & $\begin{array}{l}\text { Under- } \\
\text { flow } 1\end{array}$ & $\begin{array}{c}\text { Additional } \\
\text { recharge }{ }^{2} \\
\text { or reduced } \\
\text { pumpage }\end{array}$ & Total $^{3}$ & $\begin{array}{l}\text { Evapo- } \\
\text { trans- } \\
\text { pira- } \\
\text { tion }\end{array}$ & $\begin{array}{l}\text { Under- } \\
\text { flow }\end{array}$ & $\begin{array}{l}\text { Estimated } \\
\text { pumpage }\end{array}$ & Total $^{3}$ & $\begin{array}{c}\text { Net } \\
\text { outflow }\end{array}$ \\
\hline 1941 & (1) & 29,840 & 34,020 & 14,240 & 4,590 & 82,690 & 7,850 & 15,460 & 61,370 & 84,680 & 1,990 \\
\hline $1942-46$ & (2) & 29,840 & 34,020 & 13,760 & 6,650 & 84,270 & 5,840 & 14,190 & 90,380 & 110,410 & 26,140 \\
\hline $1947-49$ & (3) & 29,840 & 34,020 & 13,800 & 9,410 & 87,070 & 3,990 & 12,790 & 120,480 & 137,260 & 50,190 \\
\hline 1950 & (4) & 29,840 & 34,020 & 13,680 & 12,940 & 90,480 & 3,420 & 13,920 & 134,620 & 151,960 & 61,480 \\
\hline $1951-52$ & (5) & 29,840 & 34,020 & 13,850 & 18,850 & 96,560 & 2,680 & 13,170 & 168,950 & 184,800 & 88,240 \\
\hline $1953-57$ & (6) & 29,840 & 34,020 & 13,960 & 21,940 & 99,760 & 1,280 & 14,590 & 177,450 & 193,320 & 93,560 \\
\hline $1958-61$ & (7) & 29,840 & 46,400 & 14,150 & 14,980 & 105,370 & 2,110 & 15,570 & 160,580 & 178,260 & 72,890 \\
\hline $1962-65$ & (8) & 29,840 & 46,400 & 14,190 & 18,580 & 109,010 & 2,310 & 15,510 & 187,560 & 205,380 & 96,370 \\
\hline 1966 & (9) & 29,840 & 46,400 & 13,480 & 30,360 & 120,080 & 2,310 & 16,630 & 117,210 & 136,150 & 16,070 \\
\hline 1967 & (10) & 29,840 & 46,400 & 13,270 & 38,870 & 128,380 & 2,430 & 17,800 & 142,450 & 162,680 & 34,300 \\
\hline 1968 & (11) & 29,840 & 46,400 & 13,590 & 41,000 & 130,830 & 2,560 & 18,310 & 141,840 & 162,710 & 31,880 \\
\hline 1969 & (12) & 29,840 & 46,400 & 13,090 & 47,930 & 137,260 & 2,600 & 19,970 & 157,030 & 179,600 & 42,340 \\
\hline 1970 & (13) & 29,840 & 46,400 & 12,920 & 45,030 & 134,190 & 2,580 & 18,710 & 187,590 & 208,880 & 74,690 \\
\hline 1971 & (14) & 29,840 & 46,400 & 12,810 & 41,690 & 130,740 & 2,680 & 18,850 & 192,410 & 213,940 & 83,200 \\
\hline 1972 & (15) & 29,840 & 46,400 & 12,620 & 42,830 & 131,690 & 2,830 & 19,120 & 196,250 & 218,200 & 86,510 \\
\hline 1973 & (16) & 29,840 & 46,400 & 12,530 & 47,050 & 135,820 & 2,690 & 18,210 & 217,400 & 238,300 & 102,480 \\
\hline 1974 & (17) & 29,840 & 46,400 & 12,470 & 48,500 & 137,210 & 2,630 & 17,000 & 222,650 & 242,280 & 105,070 \\
\hline 1975 & (18) & 29,840 & 46,400 & 12,460 & 48,260 & 136,960 & 2,490 & 17,980 & 232,090 & 252,560 & 115,600 \\
\hline 1976 & (19) & 29,840 & 46,400 & 12,500 & 53,380 & 142,120 & 2,240 & 18,310 & 235,950 & 256,500 & 114,380 \\
\hline 1977 & (20) & 29,840 & 46,400 & 12,430 & 44,200 & 132,870 & 2,390 & 18,150 & 195,520 & 216,060 & 83,190 \\
\hline 1978 & (21) & 29,840 & 46,400 & 12,460 & 36,340 & 125,040 & 2,500 & 18,180 & 168,600 & 189,280 & 64,240 \\
\hline 1979 & (22) & 29,840 & 46,400 & 12,480 & 43,190 & 131,910 & 2,530 & 14,650 & 180,010 & 197,190 & 65,280 \\
\hline 1980 & (23) & 29,840 & 46,400 & 13,530 & 38,940 & 128,710 & 2,490 & 16,140 & 205,230 & 223,860 & 95,150 \\
\hline 1981 & (24) & 29,840 & 46,400 & 13,170 & 40,140 & 129,550 & 2,470 & 16,710 & 226,290 & 245,470 & 115,920 \\
\hline 1982 & (25) & 29,840 & 46,400 & 13,370 & 31,720 & 121,330 & 2,530 & 16,420 & 199,660 & 218,610 & 97,280 \\
\hline 1983 & (26) & 29,840 & 46,400 & 13,580 & 27,280 & 117,100 & 2,550 & 16,440 & 183,350 & 202,340 & 85,240 \\
\hline 1984 & (27) & 29,840 & 46,400 & 13,490 & 28,260 & 117,990 & 2,560 & 16,820 & 185,110 & 204,490 & 86,500 \\
\hline 1985 & (28) & 29,840 & 46,400 & 13,500 & 30,170 & 119,910 & 2,510 & 16,970 & 207,970 & 227,450 & 107,540 \\
\hline 1986 & (29) & 29,840 & 46,400 & 13,430 & 25,560 & 115,230 & 2,400 & 17,100 & 199,460 & 218,960 & 103,730 \\
\hline
\end{tabular}

${ }^{1}$ This value represents total inflow as ground-water underflow.

2Includes streamflow infiltration, irrigation retum flow, sewage-effluent retum flow, and industrial return flow.

${ }^{3}$ Total of estimated inflow or outflow value used in the regional model.

Santa Cruz River were about $8,100 \mathrm{ft}^{2} / \mathrm{d}$ in layer 1 and ranged from 34 to $6,600 \mathrm{ft}^{2} / \mathrm{d}$ in layer 2 . On the basis of numerous hydrographs, the boundary heads were held constant for inflow along the Santa Cruz River. The conductances were based on steadystate gradients and flows at the infow and outflow boundaries. The conductances of the ground-water inflow and outflow boundaries were constant for the entire transient simulation.

Storage was simulated as specific yield in layer 1 to reflect water-level decline in the unconfined part of the aquifer system. The initial storage value was specified as a specific-yield value where either layer 1 or layer 2 was the uppermost layer. These values were initially indexed on the textural subregions (fig. 8) of the Fort Lowell Formation and upper Tinaja beds, respectively, with values of 0.13 for the alluvial-fan subregions, 0.10 and 0.08 for the interfingered subregions, and 0.05 for the playa subregions. A confined storage coefficient of $1 \times 10^{-4}$ was specified for layer 2 where confined by layer 1 , and a specific-yield value was specified in the rest of layer 2 . Where confined, layer 2 was treated as convertible and storage values were changed from $1 \times 10^{-4}$ to a specific-yield value if the overlying layer 1 cell was desaturated. The 
specific-yield distribution shown in figure 15 was determined primarily by calibration of the storagedepletion period ending in 1965 . These distributions were used for simulation of the entire historical period from 1940-85. In this final distribution, specific yield in layers 1 and 2 was increased to 0.18 along the Santa Cruz River and its tributaries similar to the specific-yield distribution by the Santa Cruz River in the Avra Valley model (Hanson and others, 1990) and to 0.15 in the flood plain east of the Santa Cruz River in T. 13 S., Rs. 13 and $14 \mathrm{E}$., and north of the confluence with the Rillito. Specific yield was decreased to 0.05 in the 4-square-mile area of the central well field (T. 14 S., R. 14 E., secs. 11-14), and is additionally surrounded by cells reduced to 0.08 . A similar reduction was required in the analog model (Anderson, 1972). These specific-yield values are within the range of previous estimates (White and others, 1966; Moosburner, 1972; Anderson, 1972; Matlock and Davis, 1972; Davidson, 1973; Whallon, 1983; Freethey and others, 1986).

Streamflow infiltration was held constant in this model for 1940-57 (table 4), although the previous models varied streamflow infiltration annually on the basis of Burkham's (1970) relation with discharge (table 3). Burkham's relation is based on all floodflows, which include summer monsoonal, fall-winter cyclonic, and winter frontal storm types. As was required with the steady-state simulation, a 40-percent reduction along the northern parts of the river system was used in most of the first historical period, 1941-57. Keeping streamflow infiltration constant for $1941-57$ is also consistent with the climatic analysis of streamflow on the Santa Cruz River by Webb and Betancourt (1990). Their analysis suggests a cyclic nature to the seasonality of storm types with summer monsoonal storms dominating the source of storm types for 1930-59. Their analysis also indicates an increase in cyclonic and frontal storms and a potential increase in winter precipitation and sustained runoff since 1959 . Similarly, Keith (1981) showed a substantial increase in the percentage of winter flow since 1959. Analysis of stable isotopes in ground water (Gallaher, 1979) indicated that, on a regional scale, winter storms contribute more than summer storms in recharging the regional-aquifer system. Since 1959, summer and winter precipitation contribute equally to the streamflow infiltrated along the Santa Cruz River. Infiltration along the Santa Catalina-Rincon mountain front was mainly from winter precipitation (Gallaher, 1979; Keith, 1981). On the basis of this climatic change and spatial segregation, streamflow infiltration was increased on the Rillito and its tributaries and on the Santa Cruz River north of the Rillito confluence to the full estimate made by Burkham (1970) for 1958-86. Although increasing the streamflow infiltration to 90 percent of Burkham's estimate appears paradoxical, this was considered the best conservative increase for the remaining historical simulation (1959-86) in lieu of having better estimates of streamflow infiltration segregated by storm types and seasonal cycles. The same method for distributing the predevelopment cell-by-cell infiltration was used for this wetter period (fig. 16). The use of a constant average streamflow and reduced ground-water underflow resulted in about 5,000 acre-ft/yr more recharge than was simulated by Anderson's analog model (1972) for 1940-64, which is probably within the range of uncertainty in estimation of the streamflow infiltration along most of the nine reaches.

Increased recharge resulted, in part, from deep percolation of excess irrigation water applied to fields, mine return flow, and infiltration of sewage effluent along the Santa Cruz River (table 4). Irrigation return flow was simulated through the use of recharge wells returning water at the estimated rate of irrigation return flow. For the storagedepletion period (1941-65), estimated analogmodel pumpage was reduced by Anderson (1972) to account for irrigation return flows and problems with consumptive-use factors. In the storagedepletion period (1941-65), simulated agricultural return flows were of the pumpage estimated by Anderson (1972) in most areas. An additional 20 percent return flow in simulated pumpage that may represent even higher return flows along the Santa Cruz River flood plain in the Cortaro area and south of Tucson in the south half of T. 14 S. and Tps. 15 and 16 S., R. 13 E., was required for 1951-65 for this model and the analog model (Anderson, 1972). Irrigation return flow was initially assumed to be 26 percent of the estimated total pumpage for irrigation in the late 1960's and 20 percent in the 1970's and 

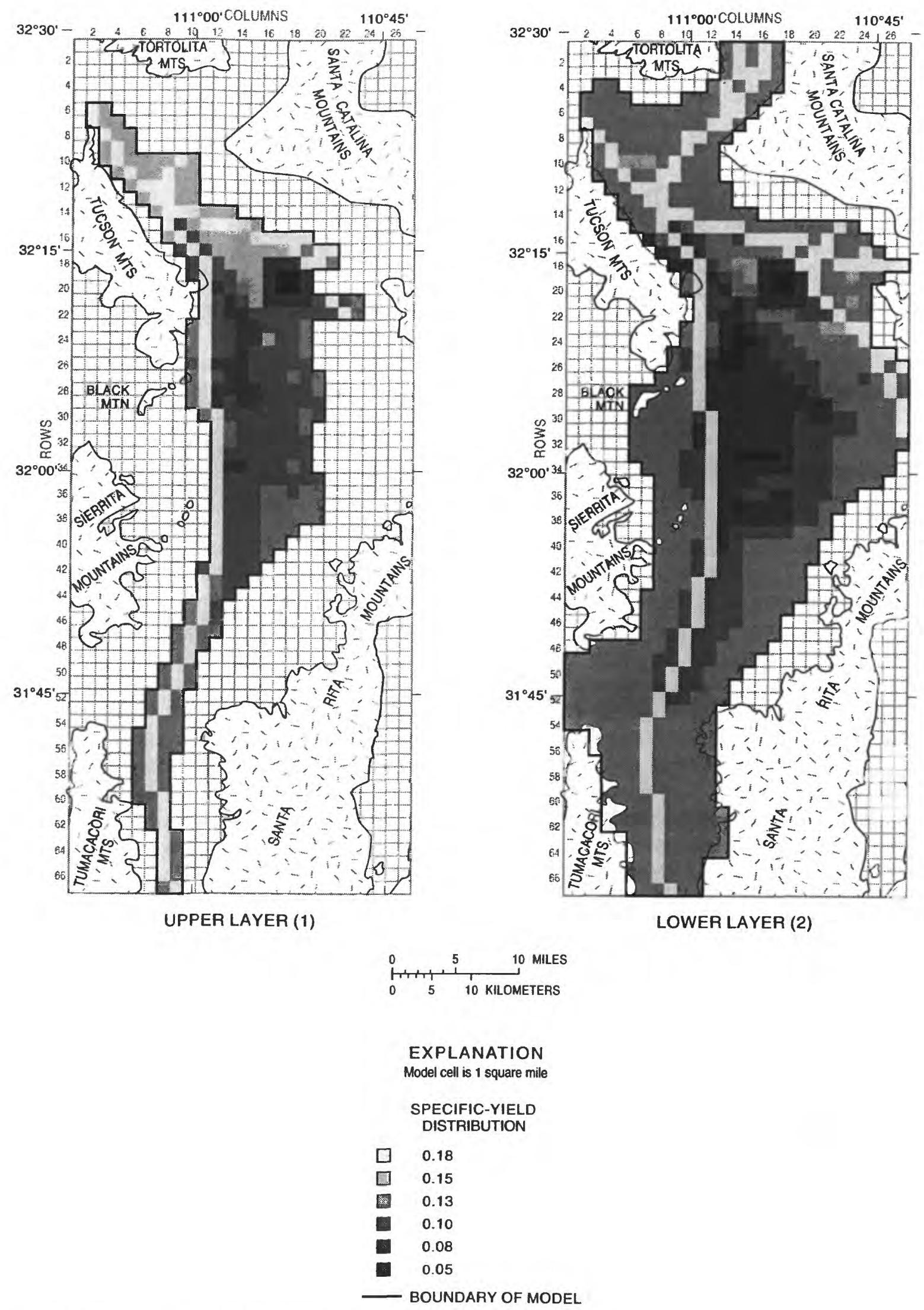

Figure 15. Specific yield of model layers 1 and 2. 

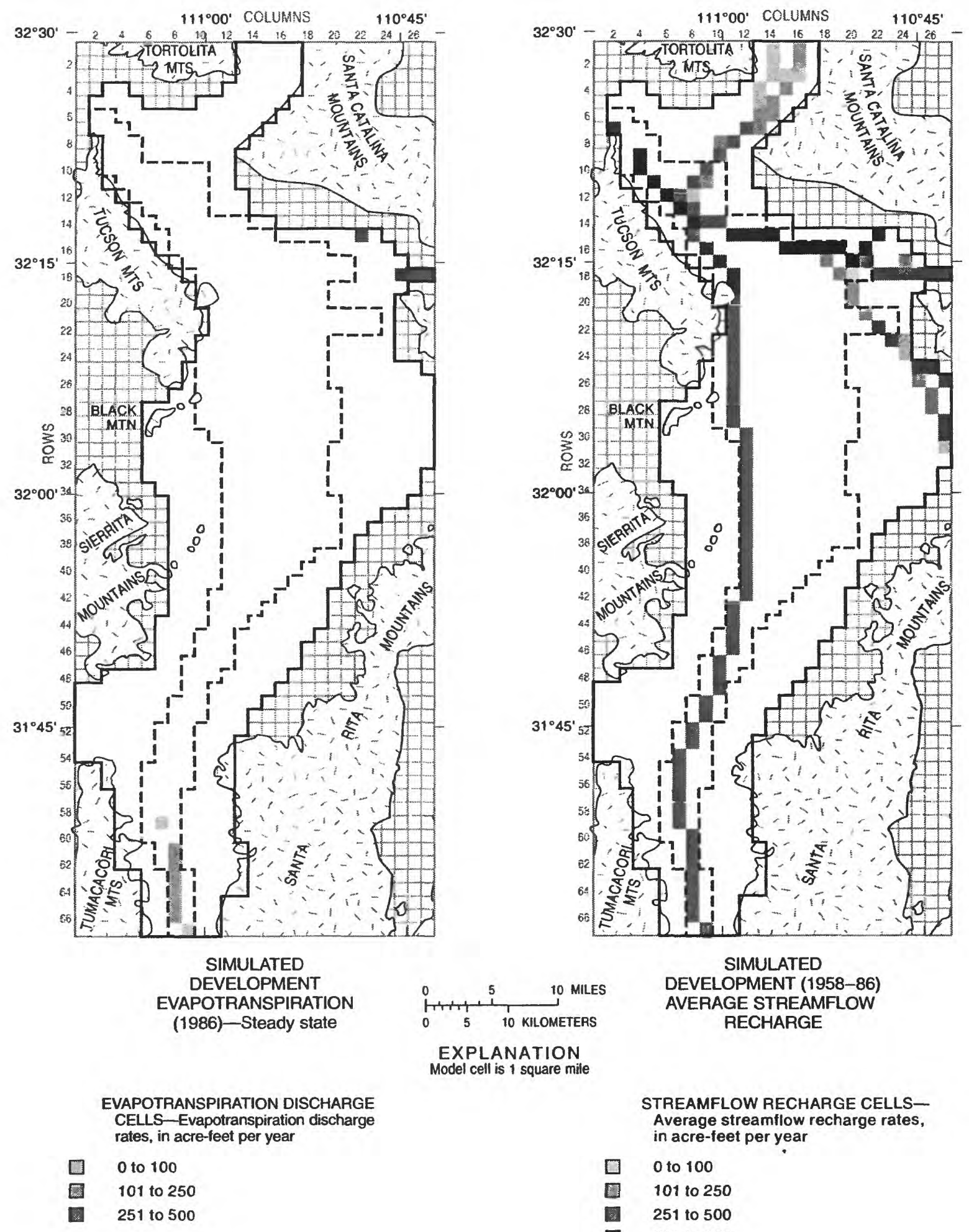

STREAMFLOW RECHARGE CELLSAverage streamflow recharge rates, in acre-feet per year

口 0 to 100

[.] 101 to 250

(1) 251 to 500

. 501 to 800

Greater than 800

BOUNDARY OF MODEL

- Lower layer (2)

- - Upper layer (1)

Figure 16. Simulated evapotranspiration (1986) and average streamflow recharge (1958-86) for layers 1 and 2 of the upper Santa Cruz basin ground-water model. 
1980 's and were the same rates used in a regional model by Travers and Mock (1984).

Pumping for copper mining south of Tucson also resulted in a recharge component of seepage from tailings ponds (fig. 6). Estimates of seepage from tailings ponds range from less than 20 to as much as 80 percent. Mine recharge was initially simulated at 40 percent of pumpage but was later reduced to the 20 to 29 percent used by Travers and Mock (1984). These percentages produced unacceptably high water levels in the mining areas. The final calibration used recharge from tailings ponds at 20 percent of annual mine pumpages for 1958-65, recharge that averaged about 34 percent of mine pumpages for 1966-79 during the most active mining period, and recharge at 20 percent for 1980-86.

Recharge from municipal sewage-effluent treatment plants began in 1950 with significant discharge along the upper reach of the Santa Cruz River (Tps. 12 and 13 S.) starting in 1951. The effluent was varied by stress period and was simulated by recharge wells along the river channel downstream from points of sewage discharge.

Pumpage was reestimated for the entire model area, which includes parts of Pima, Pinal, and Santa Cruz Counties, in a combination of well-by-well and section-by-section (cell-by-cell) estimates. Total estimated and reported pumpage may differ for some years because of omission in reported pumpage, additional modeled pumpage outside of Pima County, potential estimation errors in reported pumpage for some years, and different sources of pumpage data. Pumpage for the storagedepletion period (1941-65) was from data compilations of the electrical-analog model study by Anderson (1972) for Pima County, estimates of agricultural pumpage in Santa Cruz County for the full period, and mine pumpage for 1958-65 (data from the files of the U.S. Geological Survey). For 1966-79, model pumpage was compiled from Travers and Mock (1984, v. 2) and from data provided by the City of Tucson and the Tucson Active Management Area office and hydrology section of the Arizona Department of Water Resources. For 1980-86, model pumpage was compiled from data provided by the City of Tucson, the Tucson Active Management Area office of the Arizona Department of Water Resources, and the Cortaro-Marana Irrigation District.
Simulated pumpage was less than estimated pumpage throughout the transient simulation because of recharge from return flows (table 4, fig. 17). For 1940-50, when estimated return flows were less than 13,000 acre- $\mathrm{ft} / \mathrm{yr}$, pumpage and return flow were dominated by agricultural use. In the 1950 's, estimated return flow increased to more than 22,000 acre-ft/yr when pumpage almost doubled for municipal and agricultural use. In the 1960 's, more than half the estimated return flow came from agricultural use and ranged from 15,000 to $48,000 \mathrm{acre}-\mathrm{ft} / \mathrm{yr}$. Estimated return flows in the 1970 's ranged from 36,000 to 53,000 acre-ft/yr and were characterized by almost equal amounts of return flow from agriculture and mining. In contrast, estimated return flows in the 1980 's decreased from 40,000 to 27,000 acre-ft/yr and were predominantly from almost equal amounts of irrigation and sewage return flow. Differences between estimated pumpage and the net simulated pumpage are simulated as 1.2 million acre- $\mathrm{ft}$ of return flow to the aquifer for 1941-86 in areas of Tps. 12 through $19 \mathrm{~S}$. that generally are coincident with irrigated fields, the Santa Cruz River, and mine-tailings ponds. This recharge was the source of 21 percent of estimated pumpage for 1966-86 for the entire modeled area and was simulated by a corresponding reduction from estimated pumpage in the transient simulation. The upper layer remained saturated at all active cells through the end of 1979. Most of the water derived from storage throughout the basin was from interfingered subregions where most of the pumping was occurring. However, pumpage from the central well field is mainly from an alluvial-fan subregion and becomes a relatively large part of total pumpage after 1965.

The match between measured and simulated water-level declines generally was best in the central well field on the basis of hydrographs and contours of water-level altitude (figs. 18 and 19). Differences between measured and simulated water levels generally ranged from less than 5 to $30 \mathrm{ft}$ in the central well field and from less than 5 to $60 \mathrm{ft}$ at wells along the flood plains of Cañada del Oro and the Santa Cruz River (figs. 18 and 19). Measured hydrograph slopes were matched by simulated declines throughout most of the historical simulation. Differences in slope that occur between measured and simulated hydrographs reflect the 


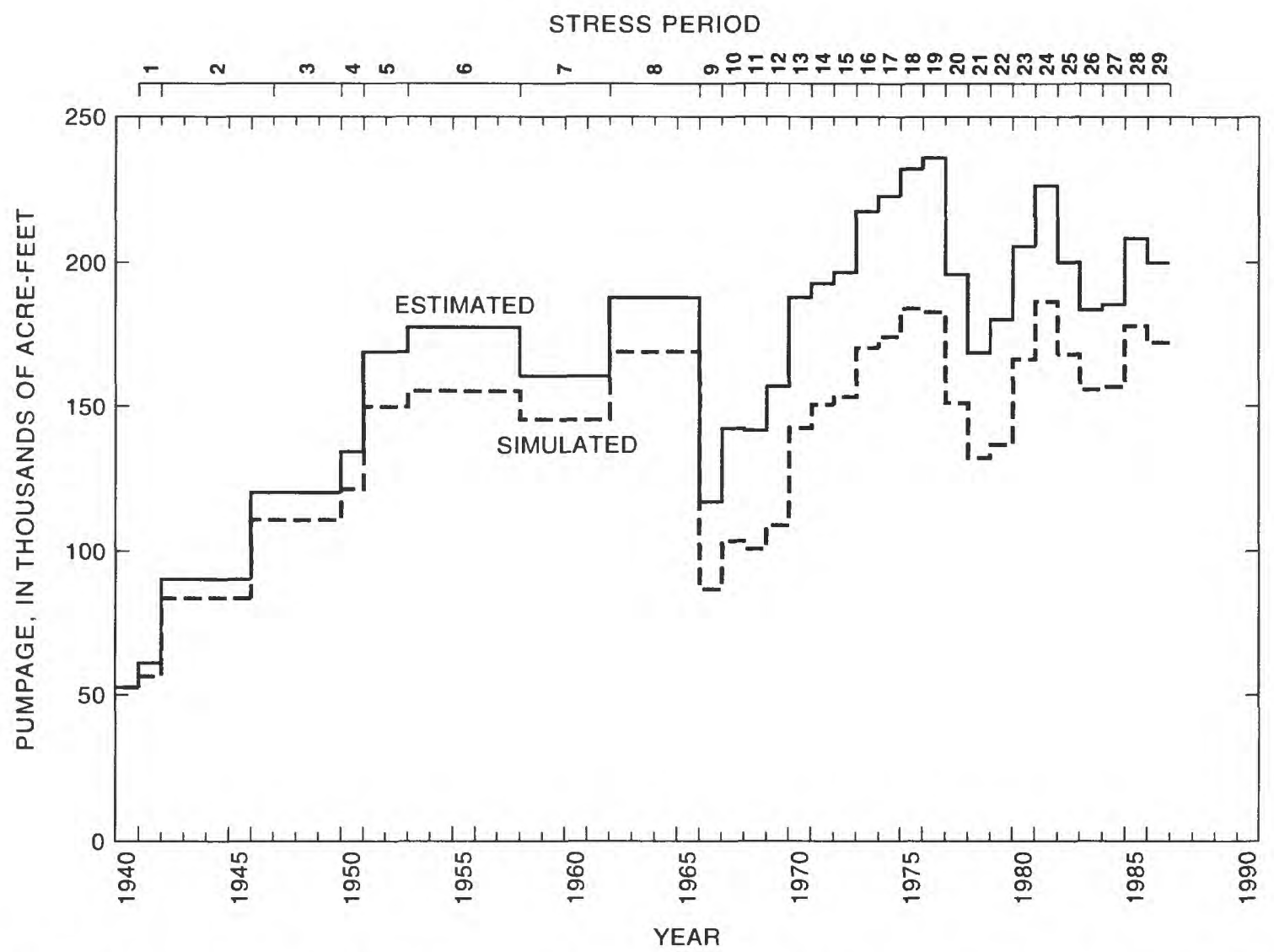

Figure 17. Estimated and simulated average annual pumpage, by simulation interval, in the upper Santa Cruz basin, 1940-86.

recovery that occurred in some wells that were adjacent to rivers after 1964 and in most wells adjacent to rivers from the mid-1970's through the mid-1980's. These differences are attributed, in part, to the higher-than-average streamflow infiltration. Simulated declines ranged from 1 to $192 \mathrm{ft}$ through 1986 (fig. 19). Contours of measured and simulated water-level altitudes generally are similar in shape and distribution throughout the upper Santa Cruz basin.

Perched ground water from industrial and agricultural activity was identified during a study of trichlorethylene contamination (Schmidt, 1985; Leake and Hanson, 1986; Babcock and others, 1987) south of metropolitan Tucson and could occur in other areas where cascading water has been observed in wells since 1965. A zone of suspected perched ground water that was identified in 1985 (T. 15 S., Rs. 13 and 14 E.) is shown in figure 18 but was not simulated. These zones, which are characterized by elevated water levels in shallow wells and cascading water in deep wells screened over large depth intervals, could be the result of mounding of return flow from industrial and agricultural pumpage above fine-grained interbeds. Wells M-S, M-D, N-S, N-D, P, and J (figs. 18 and 19) are in proximity to the affected zones where some post-1964 water levels were affected by development at depth and shallow perching of return flow. Water levels in these wells could be higher than those in the regional-aquifer system, as shown by the hydrographs from wells $\mathrm{M}-\mathrm{S}, \mathrm{N}-\mathrm{S}$, and $\mathrm{P}$, if drilled or screened at shallow depths. Conversely, water levels in these wells could be lower than those in the regional-aquifer system, as shown by the hydrographs from deep wells $M-D$, $\mathrm{N}-\mathrm{D}$, and $\mathrm{J}$, if wells are drilled and screened only at greater depths.

Measured and simulated water levels do not match the entire historical simulation at wells $U$ and 


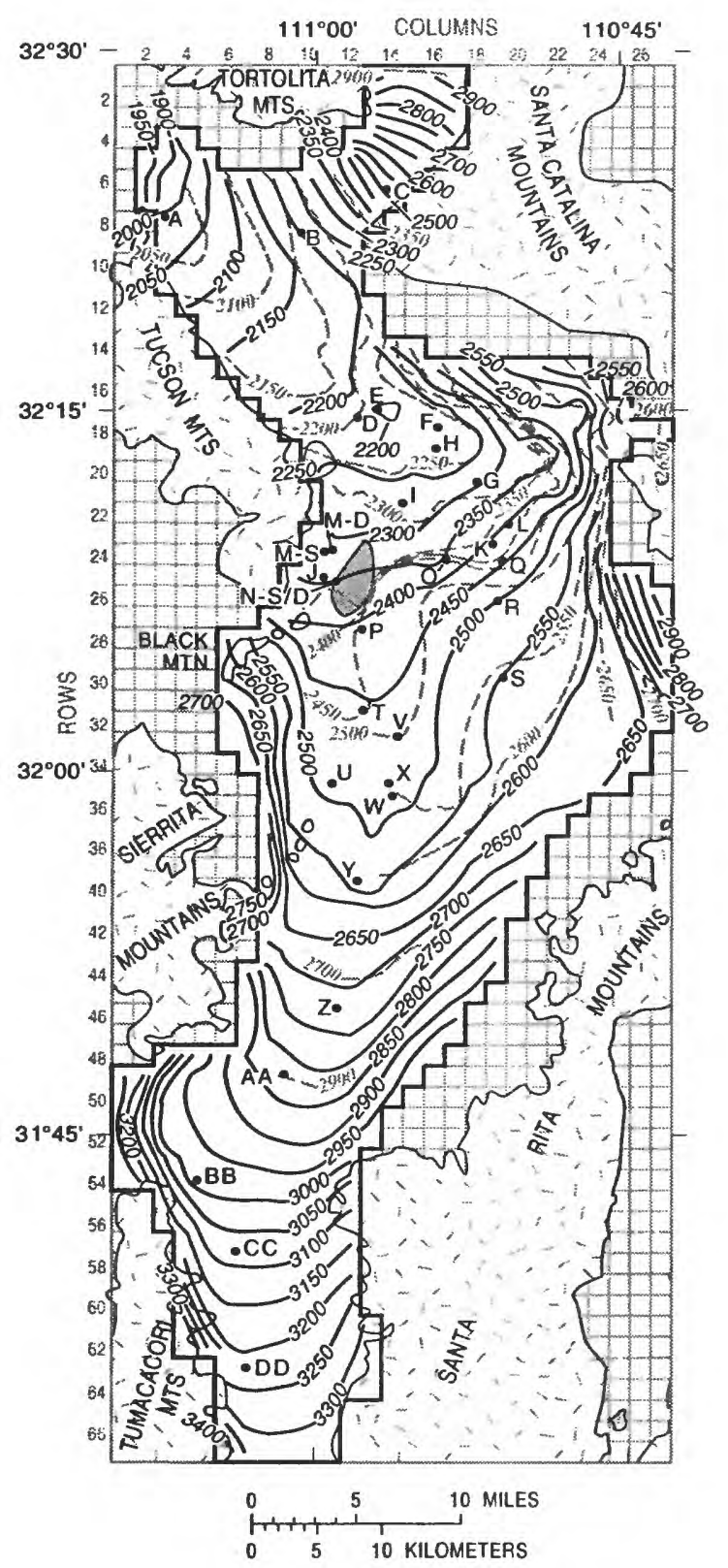

EXPLANATION

Model cell is 1 square mile

WATER-LEVEL CONTOUR, 1986-Shows altitude of water level. Contour interval 50 and 100 feet. Datum is sea level

- -2854- From measured data (Babcock and others, 1987)

-2850 - From simulated data

ZONE OF SUSPECTED PERCHED GROUND WATER, 1986 (Babcock and others, 1987)

\section{— BOUNDARY OF MODEL}

A. WATER-LEVEL MONITORING WELL-Letter corresponds to hydrograph in figure 19

Figure 18. Measured and simulated ground-water levels for layer 2 in the upper Santa Cruz basin, 1986.
O. In an area of mining and agricultural pumping, measured and simulated water levels at well $U$ match through 1972; however, water levels declined rapidly thereafter and the 300-foot-deep well was completely dry in 1975 . After 1972, the well construction and nearby pumping wells could have adversely affected the measured water levels, making the validity of the comparison with regional simulated decline questionable at this well. The rates of decline for measured and simulated water levels at well O are similar until 1982 when simulated declines indicate a recovery in response to a 75-percent local reduction in industrial pumping. One possibility for this discrepancy is that the water level in well $O$ is not representative of the average water level in the lower layer. Another possible reason is that the real aquifer system may have complexities that are not well simulated with a two-layer model. If so, future refinements of regional ground-water modeling may require additional layering of the lower alluvial units to adequately simulate ground-water flow in this part of the aquifer.

Several of the hydrographs for shallow (less than $200 \mathrm{ft}$ deep) wells adjacent to river channels (C, J, M-S, N-S, AA, CC, and DD) indicate response to sustained streamflow infiltration that was not duplicated with the two constant long-term average rates of infiltration used in the simulation. In contrast to these wells, well B (268 ft deep) adjacent to Cañada del Oro did not show streamflow effects, although the rate of measured water-level decline was greater than the simulated rate. This difference may reflect the need to simulate reduced transmissivities from reduced saturated thickness in the upper unconfined parts of the lower layer. Many wells in the central well field that are dominated by pumping stresses show no fluctuations from retum flows or climatic effects such as increased streamflow infiltration.

Pumpage and recharge greatly altered water levels and flow paths in the aquifer from 1941-86. In the transient simulation, head differences between layers 1 and 2 were less than several feet. By 1986, however, net upward flow was 67 percent less than simulated steady-state conditions. A reversal in simulated net-vertical flow from 42,500 acre-ft/yr of upward flow to 89,800 acre-ft/yr of downward flow occurred from 1940 through 1986. This reversal was, in part, from the assignment of 

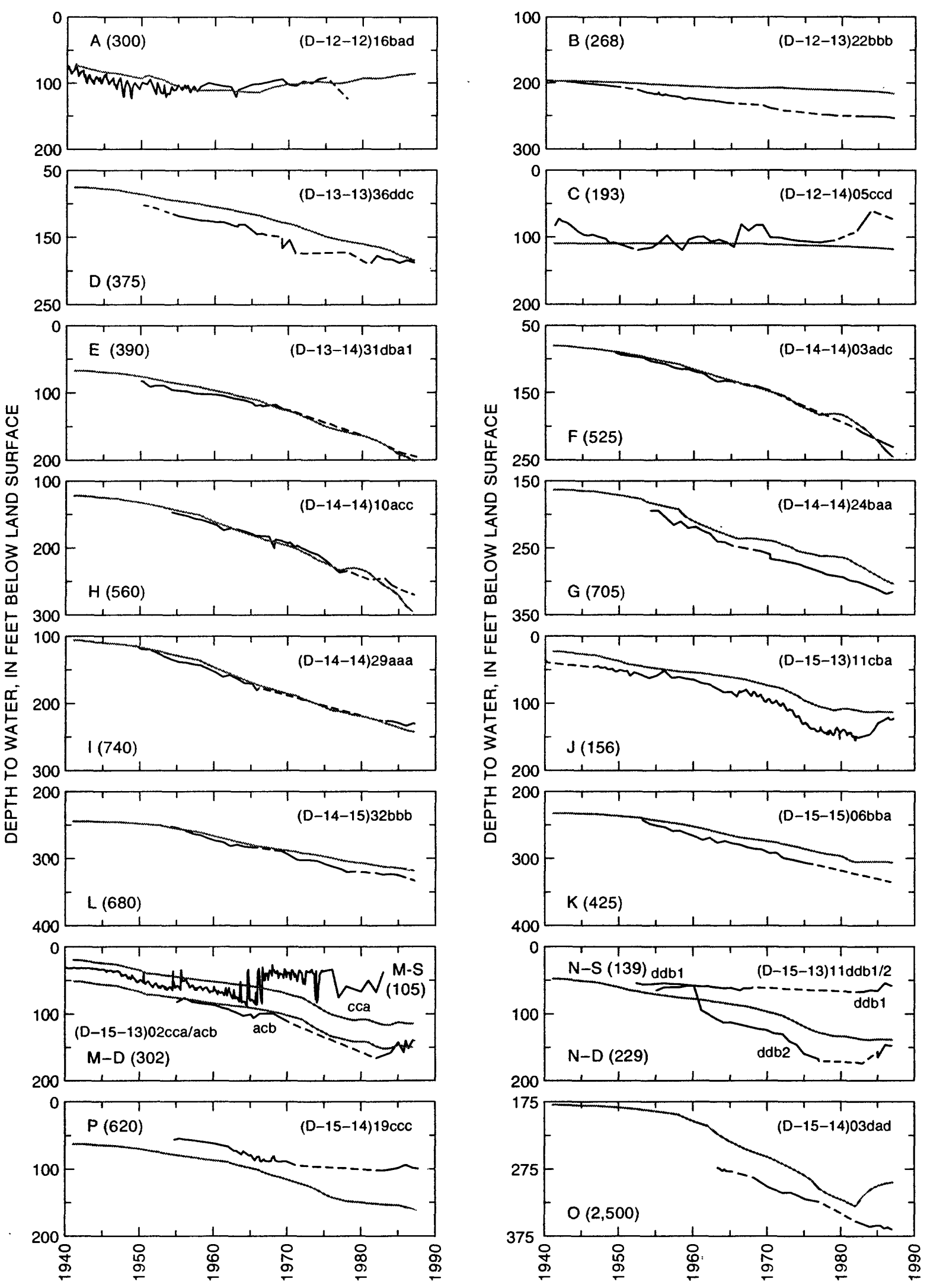

Figure 19. Measured and simulated depth to water in selected wells in the upper Santa Cruz basin, 1940-86. 

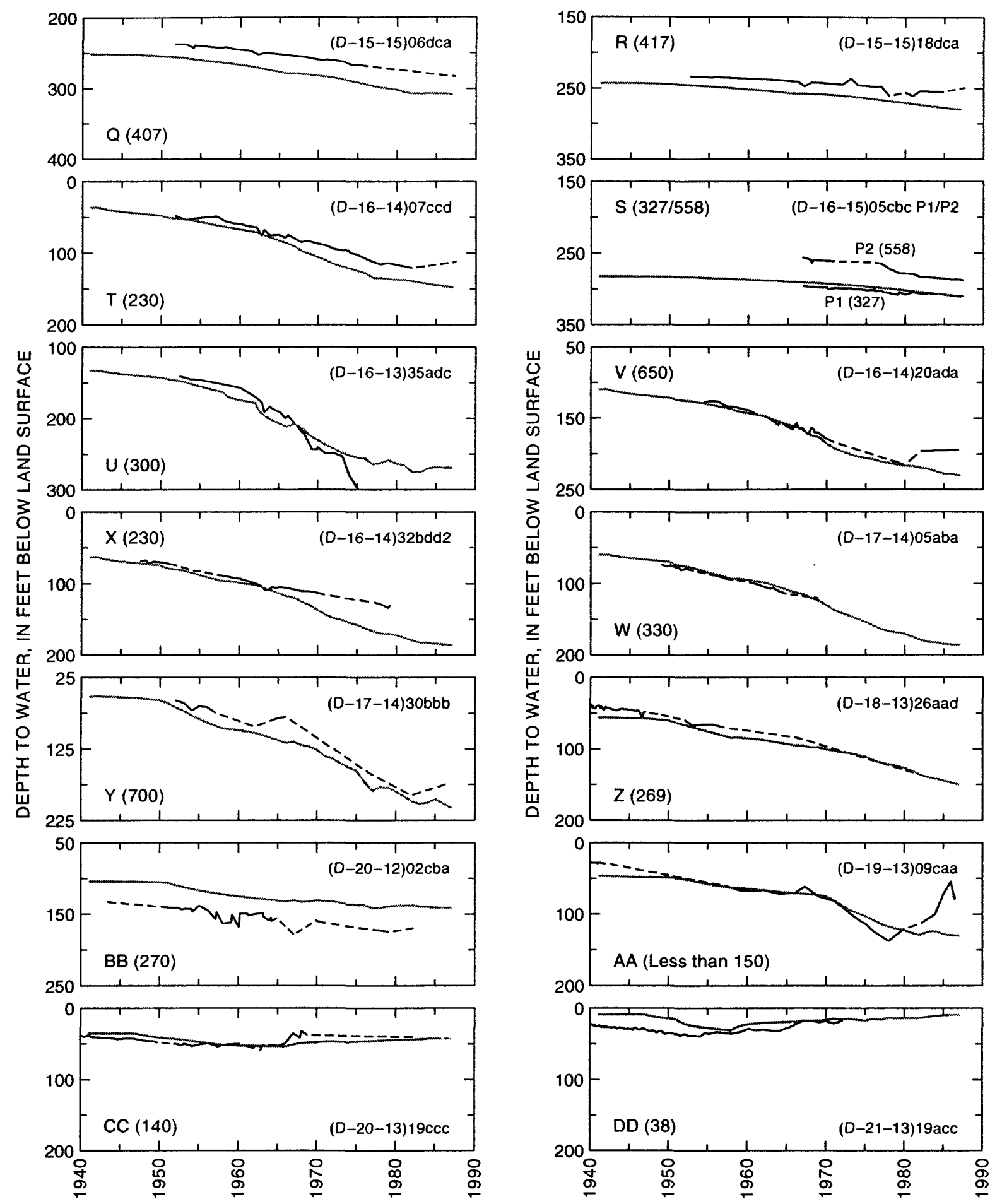

EXPLANATION

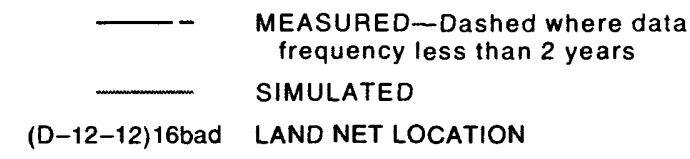

A (300) LETTER REFERS TO WELL LOCATION (SEE FIG. 15). NUMBER IN PARENTHESES IS TOTAL DEPTH OF WELL, IN FEET

Figure 19. Continued. 
pumpage in the lower layer for 1980-86. Upward flow remained the largest (34 percent of total upward flow) in the Cortaro region where the flow system is constricted between the Tucson and Santa Catalina Mountains. About 73 percent of the simulated upward flow and 35 percent of the simulated downward flow between layers occurred on the boundary of the upper layer, which in part is a result of the model configuration and could reflect vertical flow as well as some lateral flow of streamflow infiltration and mountain-front recharge across the lateral boundary of layer 1. Lateral-flow patterns were altered the most in the north-central part of the basin where the central well field has contributed to a regional cone of depression.

Simulated net withdrawal of water from aquifer storage for 1941-86 was about 3.4 million acre-ft. Evapotranspiration at the end of 1986 was simulated as 2,400 acre- $\mathrm{ft} / \mathrm{yr}$. The distribution of simulated evapotranspiration (fig. 16) is consistent with observed conditions along the Santa Cruz River in the southern part of the model (layer 1) and along Sabino and Tanque Verde Creeks in the northeastern part of the model (layer 2).

\section{Sensitivity Analysis}

Systematic change of selected model-input components and boundary conditions allowed for evaluation of model sensitivity and potential simulation error. Changes relative to the calibratedmodel components were estimated as the percentage of change in total model flow under steady-state conditions, as the difference with respect to the water levels from layer 2 of the calibrated models, as the change in water-level difference between layers 2 and 1 , and as steadystate root-mean-square errors. Sensitivity analysis indicated that the model was most sensitive to changes in transmissivity of layer 2 , streamflow or mountain-front recharge, and specific yield of layer 1 (table 5). The model was moderately sensitive to leakance between layers and was least sensitive to changes in hydraulic conductivity of layer 1 , evapotranspiration rate and extinction depth, and general-head boundary conductance (table 5). The difference in changing inflow and outflow boundary heads from general-head to constant-head boundaries in transient simulations indicated a 4-percent difference in ground-water outflow and a 4.4-percent difference in the quantity of water released from storage. Thus, the use of time-varying boundary heads affected the water levels in the boundary region but had less effect on the overall water budget. Alternative boundary conditions, such as constant-head ground-water inflow and outflow in layers 1 and 2 and increased restriction of flow between layers by reducing vertical leakance several orders of magnitude, resulted in large differences between measured and simulated head (table 5). A single specific-yield value of 0.13 as used in the RASA model improved transient simulation in some regions but made the fit worse in most areas. This may suggest that more detailed simulations of long-term desaturation of the regional-aquifer system require continual updating of specific-yield values throughout the basin to reflect desaturation of different types of sediments (for example, within textural facies) at the same time within each layer. Evaluation of model sensitivity and potential simulation error indicate a reasonable choice of aquifer components and boundary conditions for simulation of regional ground-water flow through 1986.

\section{Model Limitations}

Numerical models of ground-water flow are useful tools for assessing the response of an aquifer-system to changing stresses. Models are only an approximation of the actual flow system and are based on average and estimated conditions. The accuracy with which a model can simulate aquifer response is directly related to the accuracy of the input data, the amount of detail that can be simulated at the scale of the model, and the model discretization of time and space. The accuracy of a model is inversely related to the duration, magnitude, and distribution of pumpage and recharge simulated with the model. Thus, better estimates of agricultural pumpage and return-flow magnitude and distributions could improve the simulation of historical development. Additionally, the trial-and-error calibration process is inexact and is compounded by variable uncertainty and sensitivity of the aquifer-parameter and boundary-condition estimates. 
Table 5. Summary of sensitivity analysis

[<, Less than; >, greater than; dashes, not applicable]

\begin{tabular}{|c|c|c|c|c|c|c|c|}
\hline \multirow{2}{*}{$\begin{array}{l}\text { Hydrauilic } \\
\text { component }^{1}\end{array}$} & \multicolumn{2}{|c|}{$\begin{array}{l}\text { Calibrated } \\
\text { vailues }\end{array}$} & \multirow{2}{*}{$\begin{array}{l}\text { Multi- } \\
\text { piler }\end{array}$} & \multirow{2}{*}{$\begin{array}{c}\begin{array}{c}\text { Change } \\
\text { in head, } \\
\text { in feet }\end{array} \\
\begin{array}{c}\text { Change in } \\
\text { flow, in } \\
\text { percent }\end{array}\end{array}$} & \multirow{2}{*}{$\begin{array}{c}\begin{array}{c}\text { Difference } \\
\text { in head, } \\
\text { in feet }\end{array} \\
\text { Layer } 2\end{array}$} & \multirow{2}{*}{$\begin{array}{l}\text { Layer } 2 \\
\text { minus } \\
\text { layer } 1\end{array}$} & \multirow{2}{*}{$\begin{array}{l}\text { Root- } \\
\text { mean- } \\
\text { square- } \\
\text { error, } \\
\text { in feet }\end{array}$} \\
\hline & Minimum & Maximum & & & & & \\
\hline $\begin{array}{l}\text { Hydraulic conduc- } \\
\text { tivity layer } 1, \\
\text { in feet per day }\end{array}$ & 3 & 255 & $\begin{array}{l}0.67 \\
1.33\end{array}$ & $\begin{array}{r}-1.4 \\
1.3\end{array}$ & $\begin{array}{l}-270 \text { to }-1 \\
-128 \text { to } 89\end{array}$ & $\begin{array}{l}<1 \\
<1\end{array}$ & $\begin{array}{l}67 / 101 \\
25 / 35\end{array}$ \\
\hline $\begin{array}{l}\text { Transmissivity of } \\
\text { layer 2, in } \\
\text { feet squared } \\
\text { per day }\end{array}$ & 19 & 18,600 & $\begin{array}{r}.1 \\
.5 \\
1.4 \\
10.0\end{array}$ & $\begin{array}{l}-12.5 \\
-3.6 \\
-2.8 \\
65 .\end{array}$ & $\begin{array}{l}-900 \text { to } 1 \\
-900 \text { to } 3 \\
-114 \text { to } 190 \\
-445 \text { to } 713\end{array}$ & $\begin{array}{c}<1 \\
<1 \\
-1 \text { to } 1 \\
<1\end{array}$ & $\begin{array}{c}>1,000 / 729 \\
74 / 146 \\
22 / 31 \\
145 / 251\end{array}$ \\
\hline $\begin{array}{l}\text { Vertical-leakance } \\
\text { factor, in feet } \\
\text { per day per foot }\end{array}$ & $3 \times 10^{-2}$ & $9 \times 10^{-3}$ & $\begin{array}{l}10^{2} \\
10^{-2} \\
10^{-4}\end{array}$ & $\begin{array}{l}-0.1 \\
-0.3 \\
-2.9\end{array}$ & $\begin{array}{r}-7 \text { to } 79 \\
-182 \text { to } 75 \\
-989 \text { to }-8\end{array}$ & $\begin{array}{c}-1 \text { to }<1 \\
-4 \text { to } 21 \\
128 \text { to } 562\end{array}$ & $\begin{array}{c}11 / 17 \\
38 / 61 \\
>1,000 / 669\end{array}$ \\
\hline $\begin{array}{l}\text { Evapotranspiration } \\
\text { rate, in feet } \\
\text { per day }\end{array}$ & $1.4 \times 10^{-3}$ & $8.6 \times 10^{-3}$ & $\begin{array}{l}0.5 \\
1.5\end{array}$ & $\begin{array}{r}-0.6 \\
0.3\end{array}$ & $\begin{array}{r}-41 \text { to } 75 \\
-2 \text { to } 81\end{array}$ & $\begin{array}{r}-1 \text { to } 1 \\
0 \text { to } 1\end{array}$ & $\begin{array}{l}12 / 17 \\
16 / 25\end{array}$ \\
\hline $\begin{array}{l}\text { Evapotranspiration } \\
\text { extinction } \\
\text { depth, in feet }\end{array}$ & 25 & 25 & $\begin{array}{l}0.5 \\
1.5\end{array}$ & $\begin{array}{r}-0.9 \\
0.7\end{array}$ & $\begin{array}{r}-51 \text { to } 73 \\
-167 \text { to } 85\end{array}$ & $\begin{array}{l}-1 \text { to } 1 \\
-1 \text { to } 1\end{array}$ & $\begin{array}{l}16 / 21 \\
34 / 49\end{array}$ \\
\hline $\begin{array}{l}\text { Streamflow } \\
\text { infiltration } \\
\text { rate, in feet } \\
\text { per day }\end{array}$ & $1.5 \times 10^{-4}$ & $4.7 \times 10^{-3}$ & $\begin{array}{l}0.5 \\
1.5\end{array}$ & $\begin{array}{r}-21 . \\
21 .\end{array}$ & $\begin{array}{l}-223 \text { to } 89 \\
-128 \text { to } 73\end{array}$ & $\begin{array}{l}<1 \\
<1\end{array}$ & $\begin{array}{l}50 / 66 \\
31 / 46\end{array}$ \\
\hline $\begin{array}{l}\text { Mountain-front } \\
\text { recharge, in } \\
\text { cubic feet } \\
\text { per mile } \\
\text { per day }\end{array}$ & 864 & $5.2 \times 10^{4}$ & $\begin{array}{l}0.5 \\
1.5\end{array}$ & $\begin{array}{l}1.6 \\
18 .\end{array}$ & $\begin{array}{l}-254 \text { to } 232 \\
-173 \text { to } 54\end{array}$ & $\begin{array}{c}<1 \\
-1 \text { to } 1\end{array}$ & $\begin{array}{l}73 / 85 \\
23 / 34\end{array}$ \\
\hline $\begin{array}{l}\text { Specific yield } \\
\text { of layer } 1 \\
\text { and layer } 2\end{array}$ & 0.05 & 0.18 & $\begin{array}{l}0.8 \\
1.2\end{array}$ & ---- & $\begin{array}{l}-72 \text { to } 48 \\
-27 \text { to } 10\end{array}$ & $\begin{array}{l}0 \text { to }-3 \\
0 \text { to }-2\end{array}$ & - \\
\hline $\begin{array}{l}\text { General-head } \\
\text { boundary } \\
\text { conductance, } \\
\text { in feet } \\
\text { squared } \\
\text { per day }\end{array}$ & 34 & 12,600 & $\begin{array}{l}67 \\
1.33\end{array}$ & --.- & $\begin{array}{l}-20 \text { to } 41 \\
-72 \text { to } 0\end{array}$ & $\begin{array}{l}0 \text { to }-3 \\
0 \text { to }-2\end{array}$ & - \\
\hline
\end{tabular}

${ }^{1}$ All hydraulic components except specific yield are evaluated for the steady-state simulation.

${ }^{2}$ Change in head with respect to calibrated, steady-state head surface over active part of model grid.

${ }^{3}$ Percent of calibrated steady-state total model flow.

${ }^{4}$ First number is steady-state error for layer 1 and second number is steady-state error for layer 2. 
This model was calibrated to simulate longterm regional trends in head throughout the saturated extent of the upper alluvium. The model simulates heads fairly accurately over long periods of time in the areas with the largest amounts of pumpage (figs. 13, 14, 18, and 19). In areas of the basin where hydrogeologic data are sparse or absent, however, the accuracy of the model is more uncertain. Data are particularly sparse along the basin margins, where better estimates of aquifer properties and of time-varying streamflow infiltration and mountain-front recharge are needed. Data are sparse at depth in the areas of greatest production along the Santa Cruz River and Rillito Creek and within the central grabens such as the central wellfield. Data also are sparse at depth along graben faults, such as the I-10 fault, that probably affect the flow of water in the lower parts of the aquifer system. Observation wells and piezometer nests in these areas would help determine if model parameters, such as vertical conductance, are reasonable and would help with future refinements of the model structure. Additional isotope data and streamflow data collected on a regular basis would also help delineate the distribution of areal recharge and better define the mechanisms of streamflow and mountain-front recharge. Shallow seismic surveys could better define the saturated thickness along the basin margins. Temporal-microgravity measurements could provide better areal estimates of changes in storage in the unconfined parts of the aquifer system as well as additional specific-yield estimates. Refinements to the model could include annual streamflow variation with streamflow routing, treatment of the lower layer as several layers, and the ability to resaturate desaturated parts of the aquifer system. Resaturating cells could allow simulation of artificial-recharge projects that may become a significant source of water in the future.

The ability to simulate accurately time-varying streamflow infiltration will need to incorporate the effects of climatic cycles and El Niño-Southern Oscillations (ENSO) on natural recharge and will need to include the effects of changing stream-channel conditions. Relations developed by Burkham (1970) and by B.N. Aldridge and S.G. Brown (U.S. Geological Survey, written commun., 1971) do not hold for nonstationary processes, such as streamflow infiltration, as suggested by the analysis of streamflow duration segregated by climatic cycle and storm types (Webb and Betancourt, 1990). Time-varying runoff and recharge will need to address the effects of increased urban runoff; channelization; soil cementing along the major river beds; loss of flood-plain vegetation on some reaches from declining water levels, urbanization, and large floodflows; and increased vegetation in areas of perennial sewage-effluent infiltration. Better and more regular measurements of streamflow also will be required for realistic streamflow routing. Modeling of time-varying streamflow will require getting better ratings at stream gages located on shifting alluvial channels, better control of measurements of low flow on the major tributaries, the continuous gaging of all major and minor tributaries, and accurately estimating overbank floodflows. Simulation of stream routing (Prudic, 1989) with time-varying channel properties will be required to yield more detailed simulations of streamflow infiltration in future studies.

More model layers representing the lower parts of the aquifer system that are combined in layer 2 would allow for a more detailed simulation of the upper Tinaja beds. More layers could also improve the ability to simulate the regions represented by deep wells such as well $O$ (fig. 18). Relayering would also allow for an unconfined simulation of the peripheral parts of the upper Tinaja beds, which could improve the simulation in regions such as Cañada del Oro (well B, fig. 18) by allowing for reduced transmissivities with reduced saturated thickness. Another limitation of this model in its present form is constant hydraulic conductivity or transmissivity within these broad regional layers. The aquifer material probably changes with depth, where it becomes more dense, less porous, and finer grained and exhibits changes in thickness and layering frequency of aquifers and aquitards. Thus, as dewatering occurs, hydraulic conductivity and porosity could decrease, resulting in lower transmissivities and specific yields than simulated by this model. Additional layering could improve control over this aspect of the aquifer-system simulation. Finally, additional layering would help with more realistic subsidence simulations and would help explore the cause of vertical-head gradients that are present over different depths in 
different parts of the aquifer system (Hanson, 1989, fig. 4).

The ability to resaturate parts of the aquifer system could help facilitate future simulations that would include new forms of artificial recharge from reclaimed sewage or imported water from the Central Arizona Project. This would also help to simulate cells with unconfined conditions along the mountain fronts that could saturate and desaturate with climatic or seasonal precipitation cycles. Resaturation of desaturated cells also could help to simulate the development of perched ground-water mounds already present in parts of the basin (fig. 19).

\section{SIMULATION OF POTENTIAL LAND SUBSIDENCE}

To simulate potential land subsidence, the ground-water flow model was coupled with a numerical-subsidence routine developed by Leake and Prudic (1991). The subsidence routine computes the ultimate compaction caused by waterlevel decline. When water-level decline exceeds the preconsolidation-stress threshold, compaction becomes inelastic and nonrecoverable (Poland and others, 1972; Hanson, 1989). When decline is less than the stress threshold, compaction is elastic and recoverable. Elastic and inelastic compaction of fine-grained aquifer-system interbeds, herein referred to as aquitards (Poland and others, 1972), results in vertical drainage of pore water from the aquitards into adjacent coarse-grained aquifers. Thus, the contribution to withdrawals from aquitard storage and subsequent reduced water-level declines in the aquifer system from this additional source of water are estimated implicitly through this coupled approach to subsidence simulation.

Two potential possibilities of water-level decline and subsidence that could occur from the continued withdrawal of ground water are presented in this report. A minimum subsidence estimate was based on the assumption that aquitard inelastic compressibility will remain at a constant value within the range of values for 1986 determined from calibration of one-dimensional compaction simulations (Hanson, 1989). A maximum subsidence estimate was based on the assumption that rates of compaction will increase to potential ultimate inelastic compressibility early in the stress period (Anderson, 1988) and remain constant at this larger ultimate value. Subsidence projections, which reflect large inherent uncertainties related to the determination of aquifer-system compressibility, stress thresholds, and future pumpage, are intended only to show the relation between potential subsidence and specified features of the flow model. Refinement of results, however, could be achieved through periodic recalibration of the model to measured data from existing subsidence- and compaction-monitoring networks (Anderson, 1988; Hanson, 1987, 1989; Schumann and Anderson, 1988).

Simulation of potential subsidence through 2024 was started from transient-model heads of 1986 using aquifer properties from historical calibration and constant pumpage and recharge. Subsidence projections used model-estimated pumpage and recharge values from 1986, which were characterized by average pumpage of $199,460 \mathrm{acre}-\mathrm{ft} / \mathrm{yr}$ and average recharge of 25,560 acre-ft/yr. Simulations included yearly time steps from 1987 through 2024. Simulation of compaction was restricted to the upper alluvium (Anderson, 1988), which represents the upper layer (Fort Lowell Formation) and the upper part of the lower layer (upper Tinaja beds).

The effects of compaction in the lower alluvium; inelastic timelag; subsidence before 1986; and lateral changes in sediment layering, sorting, cementation, and density were evaluated indirectly. Compaction in the lower alluvium was considered unlikely on the basis of probable stress ranges and geologic characteristics, such as a moderate to high degree of consolidation (Anderson, 1988). Inelastic timelag (Hanson, 1987, 1989) was considered small in relation to the projection stress period of 38 years. Before 1986, measured subsidence ranged from 0 to $0.5 \mathrm{ft}$ in the north half of the basin along the Southern Pacific Railroad and Interstate 10 Highway (Strange, 1983), was not measured elsewhere in the basin (Anderson, 1988), and was assumed small compared to maximum subsidence projections. Sediment heterogeneities were simulated indirectly on the basis of assignment of inelastic storage values (Anderson, 1988; Hanson, 1989) and determination of average aquitard thickness from 
composite clay and silt distributions (fig. 8). In general, average aquitard thickness increases and layering frequency decreases with increasing clay and silt content (Anderson and Hanson, 1987; Hanson, 1989).

Other investigators have estimated (Helm, $1975,1976)$, aquitard inelastic specific storage can be as large as about $1.5 \times 10^{-4} \mathrm{ft}^{-1}$ for lacustrine and playa sediments (Ireland and others, 1982; Hanson, 1987; Epstein, 1987) and at least $1.0 \times 10^{-5} \mathrm{ft}^{-1}$ for interfingered and alluvial-fan deposits (Hanson, 1987). Maximum and minimum elastic and inelastic aquitard storage coefficients for the upper layer in each cell were the product of the saturated thickness for 1986, average percentage of clay and silt of the Fort Lowell Formation (fig. 8), and assumed constant elastic and inelastic specific storage (Poland and others, 1972; Ireland and others, 1982; Anderson, 1988; Epstein, 1987; Hanson, 1989). Similarly, the elastic and inelastic aquitard storage coefficients for the lower layer in each cell were the product of the saturated thickness part of the lower model layer represented by the upper Tinaja beds for 1986, the average percentage of silt and clay content of the upper Tinaja beds (fig. 8), and the assumed constant elastic and inelastic specific-storage values. Elastic specific storage was specified as $5.0 \times 10^{-6} \mathrm{ft}^{-1}$ for the minimum case (Helm, 1975, 1976; Ireland and others, 1982; Epstein, 1987; Hanson, 1987, 1989) and $1.0 \times 10^{-5} \mathrm{ft}^{-1}$ for the maximum case (Anderson, 1988). Aquifer storage was reduced by the aquitard elastic storage in both layers except for the confined part of the lower layer where the previous value of $1.0 \times 10^{-4} \mathrm{ft}^{-1}$ was assumed to represent only the storage in the coarse-grained interbeds (aquifers) of the aquifer system. Inelastic specific storage was specified as $1.0 \times 10^{-5} \mathrm{ft}^{-1}$ for the minimum case (Hanson, 1989) and $1.5 \times 10^{-4} \mathrm{ft}^{-1}$ for the maximum case (Helm, 1975, 1976; Ireland and others, 1982; Anderson, 1988; Epstein, 1987). Minimum storage values were derived from the calibration of historical extensometer data (Hanson, 1989) using a one-dimensional compaction model (Helm, 1975, 1976). Because of the small net compaction of less than $0.14 \mathrm{ft}$ between 1984 and 1986, minimum storage values could represent transition from elastic to inelastic compaction of the aquifer system (Hanson, 1989). Maximum storage values were derived from calibration of extensometer data from alluvial basins where inelastic compaction is in excess of several feet using one-dimensional compaction models (Helm, 1975, 1976; Ireland and others, 1982; Epstein, 1987).

Transition between elastic and inelastic compaction occurs when the water level in a sedimentary layer falls below a critical head. Water-level decline from predevelopment conditions to the critical head is defined as the preconsolidation-stress threshold (Hanson, 1989). The preconsolidation-stress threshold can range from $50 \mathrm{ft}$ in some well-sorted, fine-grained sediments that have had minimal sedimentary loading or lithification to $150 \mathrm{ft}$ in some lithified, compressed, poorly sorted, or coarse-grained sediments (Holzer, 1981). In the upper Santa Cruz basin, water-level declines required for the onset of inelastic compaction probably averages about $100 \mathrm{ft}$ (Anderson, 1988). Data were not sufficient to determine spatial variations in the preconsolidation-stress thresholds for use in the subsidence projections. The preconsolidationstress threshold was assigned maximum decline values for each cell. If the transient-simulated water-level decline was greater than $100 \mathrm{ft}$ in 1986 , this decline was used; otherwise, the value of $100 \mathrm{ft}$ of water-level decline was used (figs. 18 and 19). These maximum water-level declines were used for cell-by-cell estimates of critical head in each layer for 1987. Water-level declines ranged from 1 to $165 \mathrm{ft}$ throughout much of the north half of the basin through 1986 (figs. 14, 18, and 19). Subsidence data were not available to determine if water-level declines since predevelopment conditions in this area were greater than preconsolidation-stress thresholds for initial simulation time steps.

Simulation results indicate that an order-of-magnitude difference in potential subsidence and tens-of-feet difference in potential water-level decline are related to the range of assumed inelastic specific storage (figs. 20 and 21). Maximum simulated subsidence for an inelastic specific storage of $1.0 \times 10^{-5} \mathrm{ft}^{-1}$ was $1.2 \mathrm{ft}$ compared to $12 \mathrm{ft}$ for an inelastic specific storage of $1.5 \times 10^{-4} \mathrm{ft}^{-1}$. For $1987-2024$, maximum simulated water-level decline ranged from 245 to $273 \mathrm{ft}$ and was greatest for the smaller value of inelastic specific storage. The difference in simulated waterlevel decline is a result of the irreversible release of 

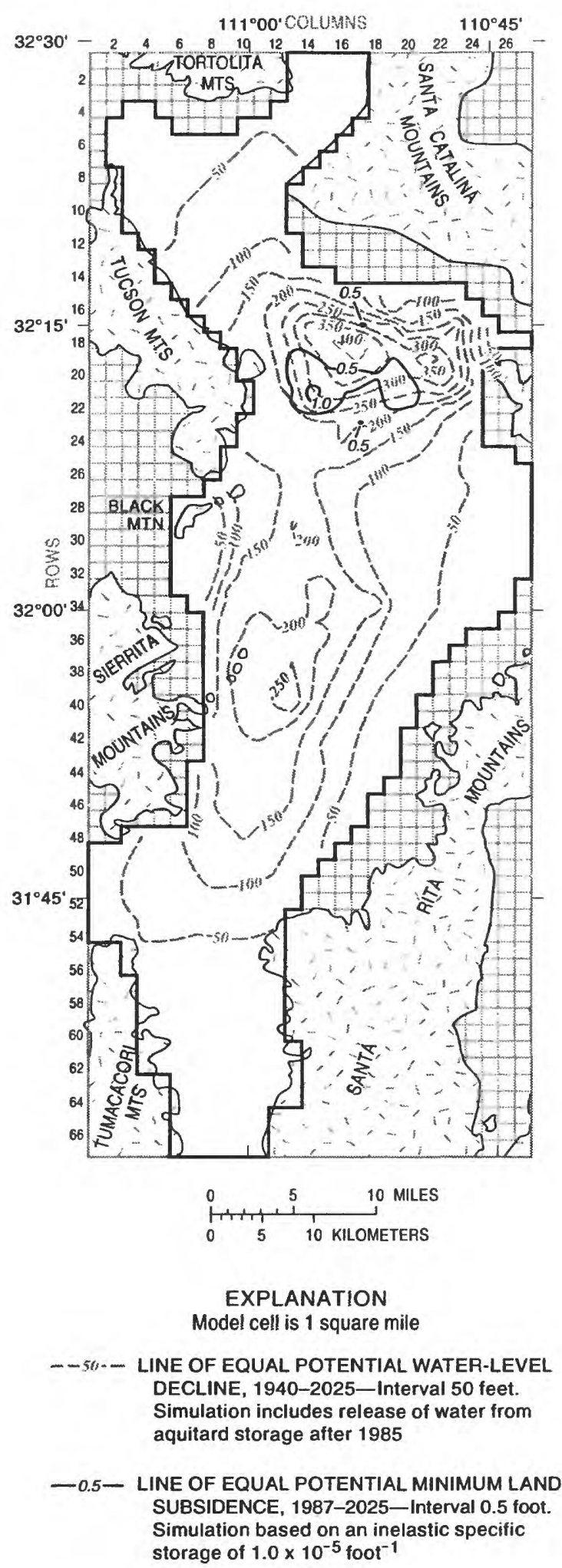

BOUNDARY OF MODEL

Figure 20. Potential water-level decline, 1940-2025, and minimum land subsidence, 1987-2025, in the upper Santa Cruz basin.
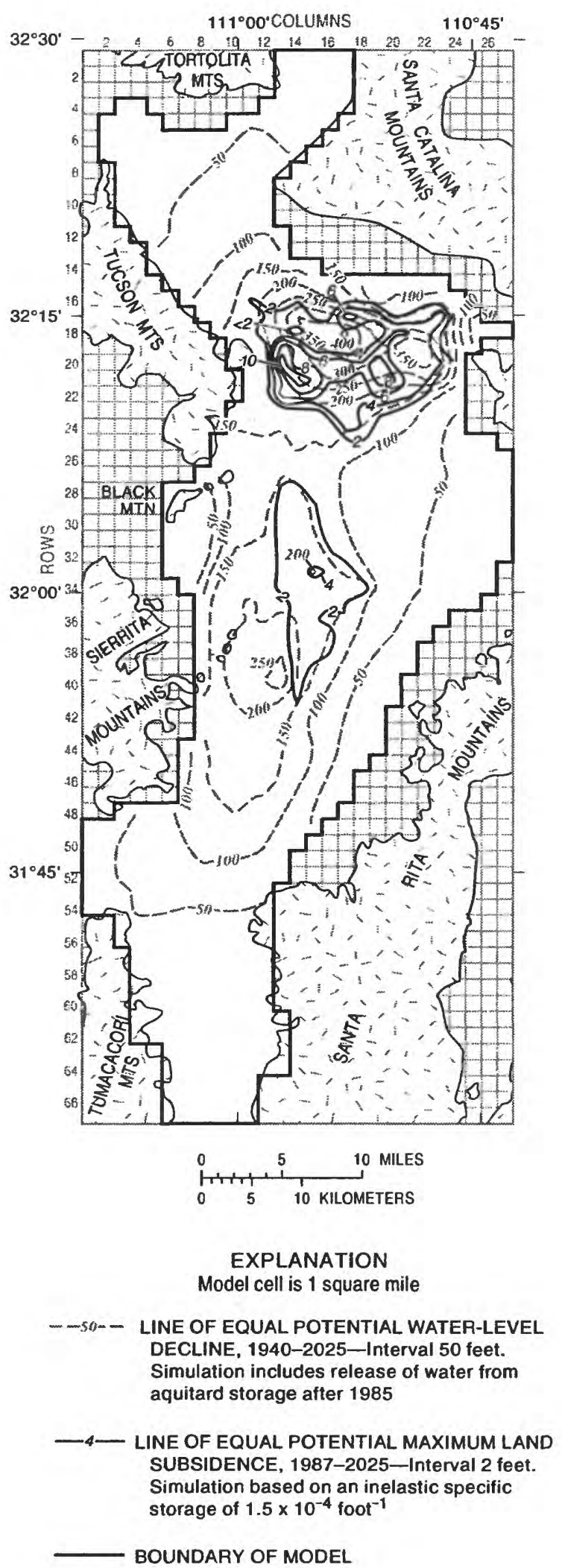

Figure 21. Potential water-level decline, 1940-2025, and maximum land subsidence, 1987-2025, in the upper Santa Cruz basin. 
water from aquitard storage. Although potential decline could be less for larger inelastic specific storage and subsidence, the lesser decline will be accompanied by greater permanent reduction of aquifer-system storage and greater drawdowns during pumping.

Simulated drawdowns indicate a potential for continued dewatering of the upper alluvium for 1987-2024. This dewatering could be accompanied by greater pumpage and dewatering of the lower alluvium than,was simulated (fig. 22). The potential contribution from aquitard storage appears to be small and almost constant for the minimum case but increases over most of the projection before becoming relatively constant for the maximum case (fig. 22). With pumping rates and distributions for 1986, the projections indicate the potential of additional desaturation between 160 and $190 \mathrm{mi}^{2}$ of the Fort Lowell Formation during the 38-year projected simulation period. Alternative distributions of pumpage were not simulated but probably would have resulted in greater water-level declines, especially if industrial pumpage related to mining and power production resumed to pumping rates prior to 1982 .

Simulations indicate a potential maximum net withdrawal of water from aquifer-system storage of 3.9 million acre-ft for 1987-2024 for the assumed pumpage and recharge. Irreversible loss of storage could be about 1.1 percent from aquitard storage for an inelastic specific storage of $1.0 \times 10^{-5} \mathrm{ft}^{-1}$ and about 12 percent for an inelastic specific storage of $1.5 \times 10^{-4} \mathrm{ft}^{-1}$. The potential aquitard-storage loss of 1 to 12 percent is much less than estimates determined for other subsidence areas on the basis of volumetric ratios of land subsidence to ground-water withdrawal. Volumetric estimates of aquitard-storage loss from regions with more than

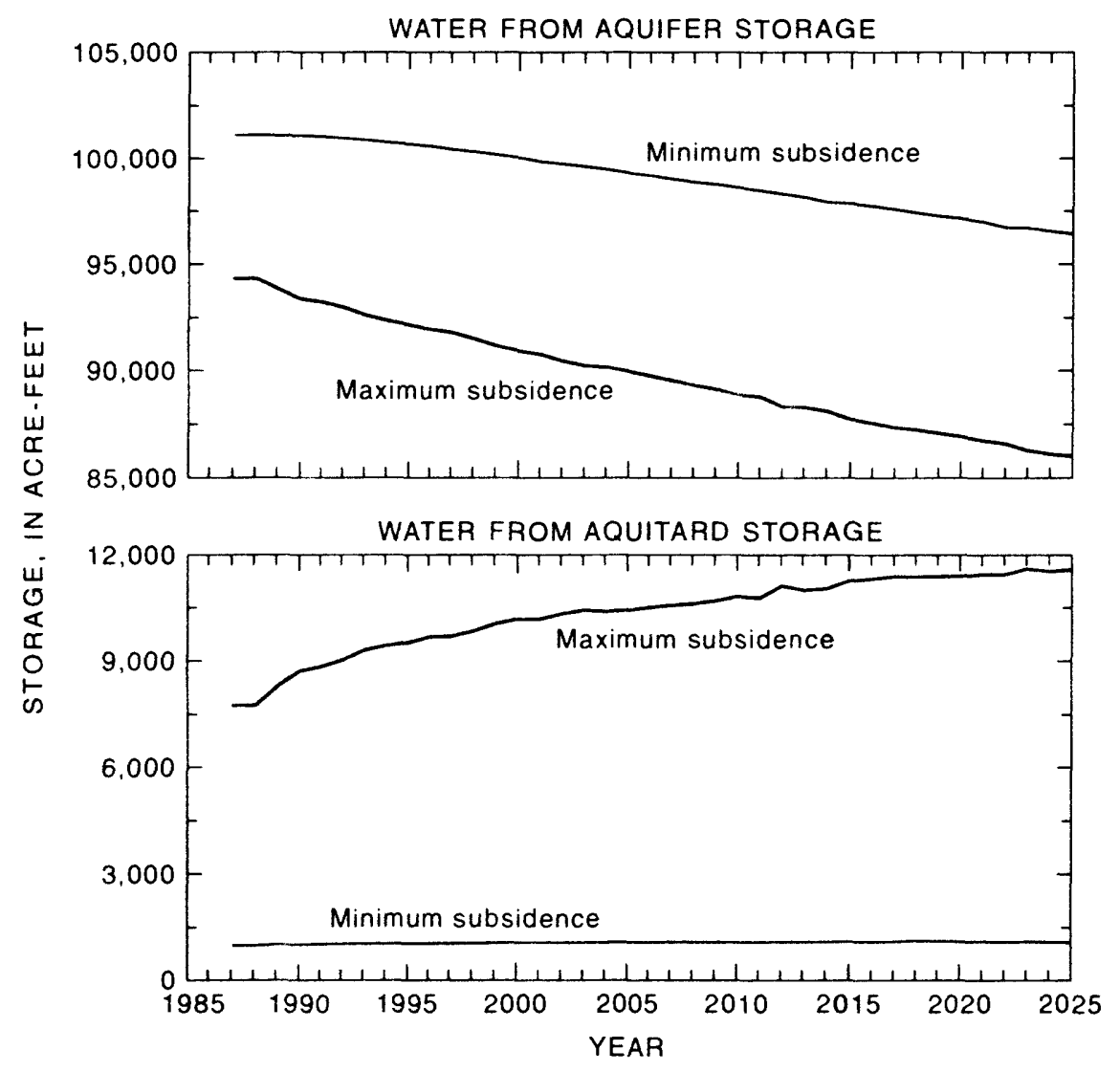

Figure 22. Subsidence projection budget components for the upper Santa Cruz basin, 1987-2025. 
$10 \mathrm{ft}$ of subsidence include 17 to 22 percent in the Galveston-Houston area, Texas (Jorgensen, 1975), 33 percent in the San Joaquin Valley, California (Poland and others, 1975), and 21 to 37 percent in the Picacho basin northwest of Avra Valley (Hanson and others, 1990). Variations in aquitardstorage loss probably are related to several factors such as visco-elastic effects (Bear and Corapcioglu, 1984), aggregate thickness of compressible layers, nonuniform distribution of preconsolidation-stress thresholds in multilayered sedimentary environments, and the general proportion of confined aquifers in an aquifer system. Simulation results suggest that contributions from aquitard storage could be smaller from predominantly unconfined aquifer systems, such as the upper Santa Cruz basin and Avra Valley, and greater from largely confined systems, such as the San Joaquin Valley, because of smaller differences between specific yield and inelastic storage coefficients.

Distribution of potential water-level decline and subsidence indicate that maximum decline and subsidence probably will occur in the north half of the basin in the central well field (figs. 20 and 21). Decline probably will be accompanied, in places, by partial dewatering of the upper alluvium. Projected declines of $438 \mathrm{ft}$ and dewatering will be greatest for minimum inelastic specific-storage values and potential subsidence of less than $1.2 \mathrm{ft}$ (fig. 20). Simulations using maximum inelastic specific-storage values indicate a potential for as much as $12 \mathrm{ft}$ of land subsidence and more than $411 \mathrm{ft}$ of water-level decline in the central well field and a potential subsidence of $4 \mathrm{ft}$ occurring in the Santa Cruz well field by the year 2025 (fig. 21).

Maximum subsidence results are comparable to previous estimates by Anderson (1988, fig. 9) in the northern part of the basin and are similar to observed conditions in the Picacho basin northwest of Avra Valley where as much as $12.5 \mathrm{ft}$ of land subsidence and $300 \mathrm{ft}$ of water-level decline had occurred by 1977 (Laney and others, 1978). In the southern part of the basin where pumping mainly for agriculture and mining was reduced in the 1980 's, maximum subsidence projections are different in magnitude and distribution from Anderson's projections (1988, fig. 9). Anderson (1988) projected an additional $6 \mathrm{ft}$ of subsidence in the southern part of the basin. One reason for this difference may be that the analysis by Anderson (1988) did not consider reductions in water-level decline from water flowing out of compacting aquitards. Other reasons for this difference may be his use of larger pumpage for 1970-78 when mining and agriculture were more active and from 5 additional years of projection. Regardless of the difference in projections, this area still has a high potential for subsidence and differential subsidence within the clay-rich sediments of a fault-bounded graben in the southcentral part of the basin if pumping were to again increase to pre-1980's rates as noted by previous investigators (Davidson, 1973; Anderson, 1988).

Konikow (1986) suggested that differences between measured and predicted water levels may be caused by a combination of factors, such as large error in assumed total pumpage during the prediction period, two-dimensional representation of a three-dimensional system, and the lack of consideration of land subsidence. The difference between model projections for the upper Santa Cruz basin indicates the potential uncertainty of longterm projections with dynamic changes in water usage, pumpage, artificial recharge, and any new potential imported water sources, such as the Central Arizona Project. Maximum subsidence projections indicate a high potential for differential subsidence between the center and edges of the basin (figs. 20 and 21) northeast of T. 15 S., Rs. 13, 14, and 15 S., and the I-10 fault (Hanson, 1989, fig. 2). These simulations do not account for the differential subsidence that could result if ultimate inelastic specific-storage values of playa sediments are larger than storage values for deposits within interfingered and alluvial-fan subregions. This potential relation is suggested by extensometer data in Avra Valley and the upper Santa Cruz basin (Hanson, 1987, 1989).

\section{SUMMARY AND CONCLUSIONS}

The upper Santa Cruz basin is a 2,870-squaremile alluvial basin from which ground water is withdrawn for agriculture, public supply, and industry. Ground-water withdrawals in the basin have exceeded natural recharge for several decades, resulting in widespread water-level declines, aquifer compaction, and land subsidence. The potential for land subsidence exists in parts of the 
upper Santa Cruz basin but is less than in basins with larger playa deposits, such as the Picacho basin. This report presents the results of the third phase of a multiple-year land-subsidence study in the upper Santa Cruz basin.

The alluvium in the upper Santa Cruz consists of upper and lower regional units that are saturated at depth and form a complex regional-aquifer system. The upper alluvium consists of alluvial-fan, playa, and interfingered depositional environments. Deposits generally are coarse grained north of T. $13 \mathrm{~S}$. and fine grained in the south half of the basin within the central grabens. Geologic and geophysical data indicate that the upper alluvium is more likely to compact from the withdrawal of ground water than is the lower alluvium.

The aquifer system generally is unconfined to depths of $1,500 \mathrm{ft}$ and is bounded by impermeable bedrock on the east and west boundaries and at depth. Ground-water inflow occurs south of Tubac and north of Catalina, and outflow occurs north of Rillito. Ground-water inflow was about 12,900 acre-ft/yr and outflow was about 15,260 acre-ft/yr in 1940 before significant ground-water development began. Increase in recharge after 1958 was coincident with above-average winter streamflow in the Santa Cruz River and its northern tributaries for 1959-86. Combined recharge from infiltration of streamflow and mountain-front recharge contributed an additional $63,860 \mathrm{acre}-\mathrm{ft} / \mathrm{yr}$ for 1940-57 and about 76,250 acre-ft/yr for 1958-86. Irrigation return flow, mine return flow, and sewage effluent contributed significantly to areal recharge from the 1950's through the 1980's. Movement of water in the aquifer generally is south to north in the southern part of the basin and southeast to northwest in the northern part. On the basis of aquifer-test estimates and previous model calibrations, transmissivity ranges from 18 to $55,000 \mathrm{ft}^{2} / \mathrm{d}$ in the lower alluvium and hydraulic conductivity ranges from 3 to $1,100 \mathrm{ft} / \mathrm{d}$ in the upper alluvium. Estimates of specific yield range from 0.03 to 0.25 and average 0.12 to 0.15 .

Annual reported ground-water pumpage increased from 48,300 acre-ft in 1940 to 269,000 acre-ft in 1975; pumpage in 1986 was 195,000 acre-ft for the part of the upper Santa Cruz basin in Pima County. Of the 7.8 million acre- $\mathrm{ft}$ of reported pumpage for 1940-86, 52 percent was used for agriculture, 33 percent was used for public supply, and 15 percent was used for industry. In 1986, the largest use of ground water was for public supply. Ground-water pumpage in excess of recharge has altered the natural flow system. Natural flow paths have shifted toward pumping centers, perched ground-water systems have developed above the regional system, transmissivity has decreased, and the vertical effective stress has increased, resulting in some compaction of the aquifer system.

A numerical ground-water flow model of the upper Santa Cruz basin was developed to simulate predevelopment conditions in 1940, ground-water withdrawals for 1941-86, and potential water-level declines and subsidence for 1987-2024. Estimated natural recharge, which averaged 63,860 acre-ft/yr for 1940-57 and 76,240 acre-ft/yr for 1958-86, represents 40 percent of the pumpage for 1966-86. The increase in recharge after 1958 was coincident with above-average winter streamflow in the Santa Cruz River for 1959-86. Artificial recharge averaged $14,400 \mathrm{acre}-\mathrm{ft} / \mathrm{yr}$ for 1941-65 and $39,650 \mathrm{acre}-\mathrm{ft} / \mathrm{yr}$ for 1966-86. Increased recharge after 1958 and decreased pumpage after 1975 contributed to decreased water-level declines or to recoveries after 1977 in wells near the Santa Cruz River and its tributaries. Water-level declines continue throughout most of the basin through 1986. The largest declines occurred in the central well field in the north-central part of the basin.

Simulations indicate a substantial increase in recharge from irrigation return flow after 1965 and an increase in streamflow infiltration after 1958. Recharge from irrigation return flow, sewage effluent, and mine return flow was about 1.2 million acre- $\mathrm{ft}$ and was the source of 21 percent of estimated pumpage for 1966-86. Simulated water-level declines were as much as $192 \mathrm{ft}$ by 1987. The net withdrawal in aquifer storage for 1941-86 was about 3.4 million acre-ft and was mainly derived from interfingered subregions where most pumping occurs. On the basis of model calibration, transmissivity ranges from 19 to $18,600 \mathrm{ft}^{2} / \mathrm{d}$ in the lower layer and hydraulic conductivity ranges from 3 to $255 \mathrm{ft} / \mathrm{d}$ in the upper layer. Simulated specific yield was 0.10 to 0.08 for the interfingered subregions but ranges from 0.18 along the Santa Cruz River and its tributaries to 0.05 in the playa facies and in T. 14 S., R. 14 E., secs. 11-14. 
The starting point for potential land subsidence was simulated beginning with historical transientstate model results from 1986. Two potential scenarios of water-level decline and subsidence were simulated-a minimum subsidence projection that used estimates of inelastic specific storage of $1.0 \times 10^{-5} \mathrm{ft}^{-1}$ for 1985 and a maximum projection that used a potential ultimate inelastic specific storage of $1.5 \times 10^{-4} \mathrm{ft}^{-1}$. Projections simulated subsidence in the upper alluvium with inelastic compaction occurring after a water-level decline of $100 \mathrm{ft}$ from predevelopment conditions. The two simulations indicate a range in maximum subsidence of 1.2 to $12 \mathrm{ft}$ in the central well field in the northern part of the upper Santa Cruz basin. Simulated water-level declines ranged from 411 to $438 \mathrm{ft}$ between 1940 and 2025 and were greatest for the least potential subsidence. Projections indicate a potential maximum net withdrawal from aquifersystem storage of 3.9 million acre- $\mathrm{ft}$. The loss from aquitard storage ranges from 1 to 12 percent of the total water withdrawn for these two scenarios. The maximum projected subsidence is comparable to estimates made by Anderson (1988) and to field conditions observed in 1977 in the Picacho basin northwest of Avra Valley (Laney and others, 1978).

Simulation results indicate that the use of combined ground-water and subsidence modeling help to improve the understanding of the conceptual framework of the aquifer system. Combined simulation can also help to understand the development of the aquifer system and help formulate development decisions that could minimize the adverse effects of irreversible loss of storage from compaction. Transient-state simulations indicate the need for better estimates of areal recharge, extent of perched aquifers, and distribution of vertical head through time. Subsidence projections indicate the need for refined estimates of inelastic specific storage and the vertical and areal distribution of aquitards. The projections also indicate the need for active management of ground-water withdrawals to minimize the effect of subsidence. A periodic postaudit of the flow model combined with additional data collection would help to refine estimates and to identify changes in the hydraulic components and boundary conditions of the aquifer system through time.

\section{SELECTED REFERENCES}

Anderson, S.R., 1987, Cenozoic stratigraphy and geologic history of the Tucson basin, Pima County, Arizona: U.S. Geological Survey Water-Resources Investigations Report 87-4190, 20 p.

1988, Potential for aquifer compaction, land subsidence, and earth fissures in the Tucson basin, Pima County, Arizona: U.S. Geological Survey Hydrologic Investigations Atlas HA-713, 3 sheets.

1989, Potential for aquifer compaction, land subsidence, and earth fissures in Avra Valley, Pima and Pinal Counties, Arizona: U.S. Geological Survey Hydrologic Investigations Atlas HA-718, 3 sheets.

Anderson, S.R., and Hanson, R.T., 1987, Relation of aquifer compaction to Cenozoic depositional environments in the Tucson basin, Arizona [abs.], in Abstracts with Programs: Geological Society of America Annual Meeting and Exposition, October 26-29, 1987, Phoenix, Arizona, p. 573.

Anderson, T.W., 1972, Electrical-analog analysis of the hydrologic system, Tucson basin, southeastern Arizona: U.S. Geological Survey Water-Supply Paper 1939-C, 34 p.

1983, Implications of deep percolation to ground-water systems in south-central Arizona based on numerical-model studies, in Proceedings of the 1982 Deep Percolation Symposium, October 26, 1982: Arizona Department of Water Resources Report 4, p. 30-40.

Anderson, T.W., Freethey, G.W., and Tucci, Patrick, 1990, Geohydrology and water resources of alluvial basins in south-central Arizona and parts of adjacent states: U.S. Geological Survey Open-File Report 89-378, 99 p.

Babcock, J.A., and Hix, G.L., 1982, Annual static water level basic data report, Tucson basin and Avra Valley, Pima County, Arizona, 1981: City of Tucson, Tucson Water Planning Division report, $21 \mathrm{p}$.

Babcock, J.A., Cameron, J.A., and Andrews, John, 1984, Annual static water level basic data report, Tucson basin and Avra Valley, Pima County, Arizona, 1983: City of Tucson, Tucson Water Planning Division report, $45 \mathrm{p}$.

Babcock, J.A., Cameron, J.A., and Brumbaugh, Lynn, 1985, Annual static water level basic data report, Tucson basin and Avra Valley, Pima County, Arizona, 1984: City of Tucson, Tucson Water Planning Division report, $47 \mathrm{p}$.

Babcock, J.A., Cameron, J.A., and Heidenreich, L.K., 1986, Annual static water level basic data report, 
Tucson basin and Avra Valley, Pima County, Arizona, 1985: City of Tucson, Tucson Water Planning Division report, $57 \mathrm{p}$.

Babcock, J.A., Heidenreich, L.K., and Bergstrom, Jim, 1987, 1986 static water level basic data report, Tucson basin and Avra Valley, Pima County, Arizona: City of Tucson, Tucson Water Planning Division report, $223 \mathrm{p}$.

Bear, Jacob, and Corapcioglu, M.Y., eds., 1984, Land subsidence-A state of art review, in Fundamentals of Transport Phenomena in Porous Media: Martinuj Nijhoff, p. 369-444.

Belan, R.A., 1972, Hydrogeology of a portion of the Santa Catalina Mountains: Tucson, University of Arizona, unpublished master's thesis, $68 \mathrm{p}$.

Betancourt, J.L., and Turner, R.M., In press, Tucson's Santa Cruz River and the arroyo legacy: Tucson, University of Arizona Press.

Blaney, H.F., and Criddle, W.D., 1949, Consumptive use of water in the irrigated areas of the upper Colorado River Basin: U.S. Department of Agriculture, Soil Conservation Service Research Provisional Report, $49 \mathrm{p}$.

Blaney, H.F., and Harris, Karl, 1951, Consumptive use and irrigation requirements of crops in Arizona: U.S. Department of Agriculture, Soil Conservation Research Provisional Report, 49 p.

Brown, S.G., 1976, Components of the water budget in the Tucson area, Arizona, 1970-72: U.S. Geological Survey Miscellaneous Investigations Series Map I-844-M, 1 sheet.

Burkham, D.E., 1970, Depletion of streamflow by infiltration in the main channels of the Tucson basin, southeastern Arizona: U.S. Geological Survey Water-Supply Paper 1939-B, 36 p.

Carpenter, M.C., 1991, Earth-fissure movements associated with fluctuations in ground-water levels near the Picacho Mountains, south-central Arizona, 1980-84: U.S. Geological Survey Professional Paper 497-H, 49 p.

Clifton, P.M., 1981, Statistical inverse modeling and geostatistical analysis of the Avra Valley aquifer: Tucson, University of Arizona, master's thesis, $190 \mathrm{p}$.

Clyma, Wayne, Rebuck, E.C., and Shaw, R.J., 1968, Hydraulic properties of the Tucson basin from short-term pumping tests: American Society of Agricultural Engineers, Pacific Coast Region Annual Meeting, April 10-11, 1968, Paper PC68-105, $18 \mathrm{p}$.

Condes de la Torre, Alberto, 1970, Streamflow in the upper Santa Cruz River basin, Santa Cruz and Pima Counties, Arizona: U.S. Geological Survey WaterSupply Paper 1939-A, 26 p.
Cruff, R.W., and Thompson, T.H., 1967, A comparison of methods of estimating potential evapotranspiration from climatological data in arid and subhumid environments: U.S. Geological Survey Water-Supply Paper 1839-M, 28 p.

Davidson, E.S., 1973, Geohydrology and water resources of the Tucson basin, Arizona: U.S. Geological Survey Water-Supply Paper 1939-E, $81 \mathrm{p}$.

Davis, G.E., and Stafford, J.F., 1966, First annual report, June 1965-June 1966, Tucson Wastewater Reclamation Project: City of Tucson, Water and Sewers Department, duplicated report, $70 \mathrm{p}$.

Eberly, L.D., and Stanley, T.B., Jr., 1978, Cenozoic stratigraphy and geologic history of southwestern Arizona: Geological Society of America Bulletin, v. 89 , no. 6, p. 921-940.

Epstein, V.J., 1987, Hydrologic and geologic factors affecting land subsidence near Eloy, Arizona: U.S. Geological Survey Water-Resources Investigations Report 87-4143, 28 p.

Fogg, G.E., 1978, A ground-water modeling study in the Tucson basin: Tucson, University of Arizona, unpublished master's thesis, $146 \mathrm{p}$.

Fenneman, N.M., 1931, Physiography of western United States: New York, McGraw-Hill, 534 p.

Freethey, G.W., 1986, Considerations in modeling ground-water flow in the alluvial basins of Arizona, in Anderson, T.W., and Johnson, A.I., eds., Regional Aquifer Systems of the United States, Southwest Alluvial Basins of Arizona: American Water Resources Association Monograph Series 7, p. 57-67.

Freethey, G.W., and Anderson, T.W., 1986, Predevelopment hydrologic conditions in the alluvial basins of Arizona and adjacent parts of California and New Mexico: U.S. Geological Survey Hydrologic Investigations Atlas HA-664, 3 sheets.

Freethey, G.W., Pool, D.R., Anderson, T.W., and Tucci, Patrick, 1986, Description and generalized distribution of aquifer materials in the alluvial basins of Arizona and adjacent parts of California and New Mexico: U.S. Geological Survey Hydrologic Investigations Atlas HA-663, 4 sheets.

Gallaher, B.M., 1979, Recharge properties of the Tucson basin aquifer as reflected by the distribution of a stable isotope: Tucson, University of Arizona, unpublished master's thesis, $92 \mathrm{p}$.

Halpenny, L.C., and Greene, D.K., 1965, Appraisal of 1965 test drilling in Avra Valley: Tucson, Arizona, City of Tucson, consultants report, $80 \mathrm{p}$.

Hanson, R.T., 1987, One-dimensional modeling of aquifer-system compaction in south-central Arizona 
[abs.]: American Geophysical Union, v. 68, no. 44, p. 1300-1301.

1989, Aquifer-system compaction, Tucson basin and Avra Valley, Arizona: U.S. Geological Survey Water-Resources Investigations Report 88-4172, $69 \mathrm{p}$.

Hanson, R.T., Anderson, S.R., and Pool, D.R., 1990, Simulation of ground-water flow and potential land subsidence, Avra Valley, Arizona: U.S. Geological Survey Water-Resources Investigations Report $90-4178,41 \mathrm{p}$.

Helm, D.C., 1975, One-dimensional simulation of aquifer-system compaction near Pixley, California-1, Constant parameters: American Geophysical Union, Water Resources Research, v. 11 , no. 3 , p. $465-478$.

1976, One-dimensional simulation of aquifer-system compaction near Pixley, California-2, Stress-dependent parameters: American Geophysical Union, Water Resources Research, v. 12, no. 3, p. 375-391.

Holzer, T.L., 1981, Preconsolidation stress of aquifer systems in areas of induced land subsidence: American Geophysical Union, Water Resources Research, v. 17, no. 3, p. 693-704.

Ireland, R.L., Poland, J.F., and Riley, F.S., 1982, Land subsidence in the San Joaquin Valley, California, as of 1980: U.S. Geological Survey Professional Paper 437-I, 93 p.

Johnson, P.W., 1952, Upper Santa Cruz basin, Pima and Santa Cruz Counties, in Halpenney, L.C, and others, Ground water in the Gila River basin and adjacent areas, Arizona-A summary: U.S. Geological Survey open-file report, p. 101-114.

Johnson, R.B., 1980, Proposed water-supply augmentation for Tucson, Arizona: Tucson, University of Arizona, unpublished master's thesis, $79 \mathrm{p}$.

Jorgensen, D.G., 1975, Analog-model studies of groundwater hydrology in the Houston district, Texas: Texas Water Development Board Report 190, 84 p.

Keith, S.J.S., 1981, Stream channel recharge in the Tucson basin and its implications for groundwater management: Tucson, University of Arizona, unpublished master's thesis, $84 \mathrm{p}$.

Laney, R.L., 1972, Chemical quality of the water in the Tucson basin, Arizona: U.S. Geological Survey Water-Supply Paper 1939-D, 46 p.

Laney, R.L., Raymond, R.H., and Winikka, C.C., 1978, Maps showing water-level declines, land subsidence, and earth fissures in south-central Arizona: U.S. Geological Survey Water-Resources Investigations $78-83,2$ sheets.
Leake, S.A., and Hanson, R.T., 1987, Distribution and movement of trichloroethylene in ground water in the Tucson area, Arizona: U.S. Geological Survey Water-Resources Investigations Report 86-4313, $40 \mathrm{p}$.

Leake, S.A., and Prudic, D.E., 1991, Documentation of a computer program to simulate aquifer-system compaction using the modular finite-difference ground-water flow model: U.S. Geological Survey Techniques of Water-Resources Investigations, book 6, chap. A2, $68 \mathrm{p}$.

Matlock, W.G., and Davis, P.R., 1972, Groundwater in the Santa Cruz Valley, Arizona: University of Arizona Agricultural Experiment Station Bulletin 194, 37 p.

McDonald, M.G., and Harbaugh, A.W., 1988, A modular three-dimensional finite-difference ground-water flow model: U.S. Geological Survey Techniques of Water-Resources Investigations, book 6, chap. A1, $586 \mathrm{p}$.

McInnes, Scott, 1982, The inversion of gravity data into three-dimensional polyhedral models: Tucson, University of Arizona, prepublished manuscript, Department of Geoscience, 21 p.

Merz, A., 1985, Mountain-front recharge from the Santa Rita Mountains to the Tucson basin: Tucson, University of Arizona, unpublished master's thesis, $122 \mathrm{p}$.

Moosburner, Otto, 1972, Analysis of the ground-water system by electrical-analog model, Avra Valley, Pima and Pinal Counties, Arizona: U.S. Geological Survey Hydrologic Investigations Atlas HA-215, 2 sheets.

Mohrbacher, C.J., 1984, Mountain-front recharge to the Tucson basin from the Santa Catalina Mountains, Arizona: Tucson, University of Arizona, unpublished master's thesis, $87 \mathrm{p}$.

Murphy, B.A., and Hedley, J.D., 1984, Maps showing groundwater conditions in the upper Santa Cruz basin area, Pima, Santa Cruz, Pinal and Cochise Counties, Arizona-1982: Arizona Department of Water Resources Hydrologic Map Series Report Number 11, 3 sheets.

Olsen, M.C., 1982, Mountain-front recharge to the Tucson basin from Tanque Verde Canyon, Arizona: Tucson, University of Arizona, unpublished master's thesis, $145 \mathrm{p}$.

Oppenheimer, J.M., and Sumner, J.S., 1981, Gravity modeling of the basins in the Basin and Range province, Arizona: Tucson, Arizona Geological Society Digest, v. 13, p. 111-115.

Osterkamp, W.R., 1973, Ground-water recharge in the Tucson area, Arizona: U.S. Geological Survey 
Miscellaneous Investigations Series Map I-844-E, 1 sheet.

Pima Association of Governments, 1979, Upper Santa Cruz groundwater quality baseline report: Upper Santa Cruz basin Mines Task Force, v. 1, 71 p.

1983, Ground-water monitoring in the Tucson copper mining district: Upper Santa Cruz Basin Mines Task Force, v.p.

Platt, W.S., 1963, Land-surface subsidence in the Tucson area: Tucson, University of Arizona, master's thesis, $38 \mathrm{p}$.

Poland, J.F., Lofgren, B.E., and Riley, F.S., 1972, Glossary of selected terms useful in studies of the mechanics of aquifer systems and land subsidence due to fluid withdrawal: U.S. Geological Survey Water-Supply Paper 2025, 9 p.

Poland, J.F., Lofgren, B.E., Ireland, R.L., and Pugh, R.G., 1975, Land subsidence in the San Joaquin Valley, California, as of 1972: U.S. Geological Survey Professional Paper 437-H, $78 \mathrm{p}$.

Pool, D.R., 1986, Aquifer geology of alluvial basins of Arizona, in Anderson, T.W., and Johnson, A.I., eds., Regional Aquifer Systems of the United States, Southwest Alluvial Basins of Arizona: American Water Resources Association Monograph Series 7, p. 25-36.

Prudic, D.E., 1989, Documentation of a computer program to simulate stream-aquifer relations using a modular, finite-difference, ground-water flow model: U.S. Geological Survey Open-File Report 88-729, 113 p.

Rampe, J.J., 1985, Results of the Tucson Airport area remedial investigation, Phase I, Volume 3 , An evaluation of the potential sources of groundwater contamination near the Tucson International Airport, Tucson, Arizona: Arizona Department of Health Services duplicated report, $110 \mathrm{p}$.

Robinson, T.W., 1958, Phreatophytes: U.S. Geological Survey Water-Supply Paper 1423, 84 p.

Schmidt, K.D., 1985, Results of the Tucson Airport area remedial investigation, Phase $I$, Volume 1, Summary report: Arizona Department of Health Services duplicated report, $114 \mathrm{p}$.

Schumann, H.H., and Anderson, S.R., 1988, Landsubsidence measurements and aquifer-compaction monitoring in the Tucson basin and Avra Valley, Arizona: U.S. Geological Survey Water-Resources Investigations Report 88-4167, 15 p.

Schwalen, H.C., and Shaw, R.J., 1957, Ground water supplies of Santa Cruz Valley of southern Arizona between Rillito Station and the international boundary: University of Arizona, Agricultural Experiment Station Bulletin 288, 119 p.
Sellers, W.D., and Hill R.D., eds., 1974, Arizona climate, 1931-1972: Tucson, University of Arizona Press, $2 \mathrm{~d}$ ed., $616 \mathrm{p}$.

Smith, G.E.P., 1910, Groundwater supply and irrigation in the Rillito Valley: University of Arizona, Agricultural Experiment Station Technical Bulletin $64,244 \mathrm{p}$.

State of Arizona, 1980, Arizona Ground-Water Management Act of 1980: Arizona Revised Statutes, section 45-401 through 45-636 (supplement 1981-82), v.p.

Strange, W.E., 1983, Subsidence monitoring for State of Arizona: Washington, D.C., U.S. Department of Commerce, National Oceanic and Atmospheric Administration report, $74 \mathrm{p}$.

Thome, P.D., 1983, A chemical and isotopic study of ground water from the Tucson Mountains, Arizona: Tucson, University of Arizona, unpublished master's thesis, $81 \mathrm{p}$.

Travers, B.C., and Mock, P.A., 1984, Groundwater modeling study of the upper Santa Cruz basin and Avra Valley in Pima and Santa Cruz Counties, southeastern Arizona: Arizona Department of Water Resources, Hydrologic Division, 2 v., v.p.

Tucci, Patrick, and Pool, D.R., 1986, Use of geophysics for geohydrologic studies in the alluvial basins of Arizona, in Anderson, T.W., and Johnson, A.I., eds., Regional Aquifer Systems of the United States, Southwest Alluvial Basins of Arizona: American Water Resources Association Monograph Series 7, p. 37-56.

Tucci, Patrick, Schmoker, J.W., and Robbins, S.L., 1982, Borehole-gravity surveys in basin-fill deposits of central and southern Arizona: U.S. Geological Survey Open-File Report 82-473, 23 p.

Turner, S.F., 1958, Ground-water resources available for use on the Cortaro and Marana Farm areas, Pima County, Arizona: City of Tucson consultants report, $26 \mathrm{p}$.

1959, Water-resources available to the City of Tucson, Pima County, Arizona: City of Tucson consultants report, $49 \mathrm{p}$.

Turner, S.F., 1946, Ground water in the Tucson quadrangle, Arizona: U.S. Geological Survey open-file report (unnumbered), $15 \mathrm{p}$.

Turner, S.F., and others, 1943, Ground-water resources of the Santa Cruz basin, Arizona: U.S. Geological Survey open-file report (unnumbered), $84 \mathrm{p}$.

1947, Further investigations of the ground-water resources of the Santa Cruz basin, Arizona: U.S. Geological Survey open-file report (unnumbered), $49 \mathrm{p}$. 
University of Arizona, 1944, Arizona agriculture 1944: University of Arizona Agricultural Experiment Station Bulletin 192, $18 \mathrm{p}$. 1948, Arizona agriculture 1948: University of Arizona Agricultural Experiment Station Bulletin 211, $18 \mathrm{p}$. 1954, Arizona agriculture 1954: University of Arizona Agricultural Experiment Station Bulletin $252,18 \mathrm{p}$.

1963, Irrigation areas in Arizona: University of Arizona Agricultural Experiment Station Map, Folder 101, 1 sheet.

U.S. Environmental Protection Agency, 1984, Final determination of ground water system of the Upper Santa Cruz basin and Avra-Altar basin of Pima, Pinal, and Santa Cruz Counties, Arizona-Aquifer determination: Federal Register, v. 49, no. 16, OW-FRL-2511-3, p. 2948-2950.

Webb, R.H., and Betancourt, J.L., 1990, Climatic variability and flood frequency of the Santa Cruz
River, Pima County, Arizona: U.S. Geological Survey Water-Supply Paper 2379, 40 p.

Whallon, A.J., 1983, A geohydrologic study of the regional ground-water system in Avra Valley, Pima and Pinal Counties, Arizona: Tucson, University of Arizona, unpublished master's thesis, $68 \mathrm{p}$.

White, N.D., Matlock, W.G., and Schwalen, H.C., 1966, An appraisal of the ground-water resources of Avra and Altar Valleys, Pima County, Arizona: Arizona State Land Department Water-Resources Report 25, $66 \mathrm{p}$.

Williams, D., 1987, Geostatistical analysis and inverse modeling of the upper Santa Cruz basin, Arizona: Tucson, University of Arizona, master's thesis, $190 \mathrm{p}$.

Wilson, E.D., Moore, R.T., and Cooper, J.R., 1969, Geologic map of Arizona: Tucson, Arizona Bureau of Mines map, scale 1:500,000. 